\title{
Seismic Behaviour of High-rise Frame-core Tube Structures Considering Dynamic Soil-Structure Interaction
}

Xiaofeng Zhang ( $\nabla$ xiaofeng.zhang@student.uts.edu.au )

University of Technology Sydney

Harry Far

University of Technology Sydney

\section{Research Article}

Keywords: High-rise building, Frame-core tube structure, Soil-structure interaction, Numerical simulation, Seismic response

Posted Date: January 13th, 2022

DOl: https://doi.org/10.21203/rs.3.rs-1240011/v1

License: (c) (i) This work is licensed under a Creative Commons Attribution 4.0 International License.

Read Full License

Version of Record: A version of this preprint was published at Bulletin of Earthquake Engineering on March 31st, 2022. See the published version at https://doi.org/10.1007/s10518-022-01398-9. 


\section{Abstract}

As the population grows and land prices rise, high-rise buildings are becoming more and more common and popular in urban cities. Traditional high-rise building design method generally assumes the structure is fixed at the base, because the influence of soil-structure interaction is considered to be beneficial to the response of structures under the earthquake excitation. However, recent earthquakes and studies indicated that SSI may exert detrimental effects on commonly used structural systems. In this study, a numerical soil-structure model is established in Abaqus software to explore the impacts of SSI on highrise frame-core tube structures. The seismic response of frame-core tube structures with various structural heights, height-width ratios, foundation types and soil types is studied. The numerical simulation results including maximum lateral deflections, foundation rocking, inter-storey drifts and base shears of rigid and flexible base buildings are discussed and compared. The results reveal the lateral displacement and inter-storey drifts of the superstructure can be amplified when SSI is taking into account, while the base shears are not necessarily reduced. Increasing the stiffness of the foundation and the subsoil can generally increase the seismic demand of structures. It has been concluded that it is neither safe nor economical to consider only the beneficial effects of SSI or to ignore them in structural design practice.

\section{Introduction}

High-rise buildings of various structural systems are becoming more and more popular and common in urban cities due to population growth, land prices increase and lack of construction land (Al Agha et al. 2021). Therefore, it has been tried to make high-rise buildings safe and stable under different loads, especially when buildings are built on a site with poor geotechnical conditions in an earthquake-prone area. This is because the effects of horizontal loads on high-rise buildings are not linear, but increase rapidly with the increase of the building height. For instance, under horizontal loads, the overturning moment of the structure is proportional to the square of its height, and the lateral deflection at the top of the structure is proportional to the fourth power of its height (Gao et al. 2005). As a result, with the increment of building height, lateral displacement will undoubtedly become the main controlling factor in the structural design. Additionally, the structure can deform in any direction under strong earthquakes, and sometimes the displacement can be large, so the key design problem is to avoid excessive deformation that will lead to building collapse.

In traditional design method, the superstructure and the substructure are designed separately. On the one hand, the traditional assumption is that the superstructure is fixed at the base and the influence of soilstructure interaction (SSI) is ignored. Besides, the substructure is designed under the vertical load, horizontal load and moment deriving from the superstructure (El Ganainy and El Naggar 2009).

Actually, if the subsoil is stiff enough (e.g., buildings constructed on sound rock), the foundation input motion induced by an earthquake is basically identical to the free field motion and the rigid base assumption can be reasonable. In contrast, if the structure is rested on soft soil medium, the seismic 
response can be different. Firstly, the foundation is capable to resist large deformations because of its rigidity. As a result, the foundation fails to conform to the deformations of surrounding soil and thus the input motion is inconsistent with free field motion. Secondly, the seismic response of the superstructure will probably cause deformation of the ground soil, which further modifies the input motion (Wolf and Deeks 2004). Therefore, the seismic behaviour of the superstructure is influenced by the interaction between the superstructure and the underneath soil and a feedback loop will exist (Tabatabaiefar et al. 2013; Tabatabaiefar 2016; Far 2019a; Al Agha et al. 2021;). This feedback loop, in which the response of the soil affects structural behaviour and vice-versa is termed as soil-structure interaction (SSI) (Anand and Satish Kumar 2018).

It is widely believed in previous studies that SSI is beneficial to the seismic behaviour of buildings, since it elongates the natural period (Seed et al. 1976) and increases the damping of system (Wolf 1985), which tends to reduce the seismic demand of structures. Therefore, many current structure design codes recommend reducing the overall seismic coefficient when considering SSI or completely ignore SSI (NZS1170.5, 2007; NBCC 2010; GB 50011 2010; IBC 2012). However, observations from a number of earthquake damaged sites proved that this design consideration is quite harmful. Take the 1985 Mexican earthquake as an example, a totally reverse result was noticed, wherein the soft subsoil resulted to a huge increase in the seismic forces (Sharma et al. 2018). In addition, remarkable examples including damage in pile-supported bridge structures and collapse of expressway can be found in Yashinsky (1998) and Mylonakis and Gazetas (2000). Recent studies have also justified this possibility. The flexibility of foundation can increase the deformation and inter-storey drifts of the structure (Guin and Banerjee 1998; Tabatabaiefar 2012; Hokmabadi et al. 2014; Tabatabaiefar and Clifton 2016; Van Nguyen et al. 2017; Far 2019b).

Therefore, it is noted that there are some contradictory opinions when SSI is considered in the structural design practice (Mylonakis and Gazetas 2000; Far and Flint 2017). It is the complexity of SSI and lack of consensus among researchers with regard to the influence of SSI that lead to very few structure design codes provide provisions related to it. Consequently, considering SSI in design practice of the most common and worldwide prevalent building typologies has been a rarity (Anand and Satish Kumar 2018). Therefore, in response to the need for critical investigation of SSI impacts, in this study, an enhanced numerical soil-structure model is adopted to investigate the effects of SSI on a typical high-rise building structure system: reinforced concrete $(\mathrm{RC})$ frame-core tube structure. The seismic behaviour of frame-core tube structures with different structure heights, height-width ratios, foundation types and soil types are studied. The results including maximum lateral deflections, foundation rocking, inter-storey drifts and base shears for the rigidly supported and flexibly supported structures are discussed and compared.

\section{Overview Of The Structure-soil Model}

Three structural heights: 60 meters ( 20 stories), 90 meters (30 stories) and 120 meters (40 stories) are considered in this study to cover the commonly used height range of high-rise buildings. Besides, the height-width ratios of the superstructure are four, five and six respectively, with three spans in each 
direction. Two prevalent foundation types: end bearing piled foundation and classical compensated foundation are adopted. The foundation embedment depth is assumed to be 9 metres, with three basement stories. The bedrock depth is 30 metres since the most soil amplification effect occurs in the upper 30 metres of the soil profile. For each structure-soil model, two far-filed earthquakes and two nearfiled seismic records are applied. Therefore, a total of 252 cases (36 fixed base cases and 216 flexible cases) were considered. The plan view of standard stories of frame-core tube structures is shown in Fig. 1 (a), which consists of the outer frame and the inner core tube.

Figure 1 Characteristics of frame-core tube structure (a) plan view of standard storey (b) 20-storey framecore tube structure with end bearing piled foundation (height-width ratio=6) (c) 20-storey frame-core tube structure with classical compensated foundation (height-width ratio=6) $(d)$ the finite-element model

By referring to AS3600 (2018) and AS1170.4 (2007), the structural sections of buildings with various heights and widths were designed in SAP2000 software. After that, nonlinear time history analyses under four seismic records (Fig. 2) was conducted to ensure inter-storey drifts of fixed base structures with various parameters were less than $1.5 \%$ (life safe level). Grade 40 concrete with characteristic compressive strength $\left(f_{c}^{\prime}\right)$ of $40 \mathrm{MPa}$, modulus of elasticity $\left(E_{c}\right)$ of $32.8 \mathrm{GPa}$ and unit weight of 24.5 $\mathrm{kN} / \mathrm{m}^{3}$ (AS3600 2018) were adopted. In order to facilitate modelling in the subsequent finite element analyses, structures with the same height have the same dimensions of structural sections regardless of the height-width ratio. The dimensions of structural elements are summarised in Table 1.

The superstructures founded on soil deposits with different geotechnical characteristics, which are summarised in Table 2 (Tabatabaiefar et al. 2014). The reason why the maximum shear-wave velocity of ground soil $\left(V_{s}\right)$ adopted in this study is $600 \mathrm{~m} / \mathrm{s}$ is that generally when the $V_{s}$ is greater than $600 \mathrm{~m} / \mathrm{s}$, the influence of SSI is not significant (Tabatabaiefar et al. 2013).

Figure 2 Seismic records adopted in this study: (a) El Centro earthquake (b) Hachinohe earthquake (c) Kobe earthquake (d) Northridge earthquake 
Table 1

Summary of dimensions of structural elements $(m)$

\begin{tabular}{|llllll|}
\hline Structures & Stories & Columns & Beams & Shear walls & Slabs \\
\hline 20-storey & $1 \sim 5$ & $0.55 \times 0.55$ & $0.40 \times 0.40$ & 0.55 & 0.25 \\
\cline { 2 - 6 } & $6 \sim 10$ & $0.50 \times 0.50$ & $0.40 \times 0.40$ & 0.50 & 0.25 \\
\cline { 2 - 6 } & $11 \sim 15$ & $0.45 \times 0.45$ & $0.40 \times 0.40$ & 0.45 & 0.25 \\
\hline 30 -storey & $11 \sim 10$ & $0.70 \times 0.70$ & $0.50 \times 0.50$ & 0.70 & 0.25 \\
\cline { 2 - 6 } & $11 \sim 20$ & $0.60 \times 0.60$ & $0.50 \times 0.50$ & 0.60 & 0.25 \\
\hline 40 -storey & $11 \sim 30$ & $0.50 \times 0.50$ & $0.50 \times 0.50$ & 0.50 & 0.25 \\
\cline { 2 - 6 } & $11 \sim 20$ & $0.90 \times 0.90$ & $0.50 \times 0.80$ & 0.70 & 0.25 \\
& $21 \sim 30$ & $0.80 \times 0.80$ & $0.50 \times 0.80$ & 0.60 & 0.25 \\
& $31 \sim 40$ & $0.70 \times 0.70$ & $0.50 \times 0.80$ & 0.50 & 0.25 \\
\hline
\end{tabular}

Nowadays, the application of piled foundations for buildings has become increasingly common. The piled foundation generally transmits upper loads through the soft soil to the deep stiff soil or rock. In this study, end bearing piled foundation is adopted and all piles are rigidly connected with the base slab, and pile toes are fixed at the bottom of the soil to simulate the socket end of piles in bedrock (Fig. 1b). The arrangement and characteristics of pile foundation have shown in Fig. 3 and Table 3. In addition, classical compensated foundation was selected for comparison with the piled foundation model because the compensated foundation tends to induce larger foundation rotation, and the superstructure can produce more obvious lateral deflection. Therefore, this study employs classical compensated foundation and piled foundation with three basement floors overlying a $1 \mathrm{~m}$-thick RC base slab (Fig. 1b and c). The requirements for bearing capacity and maximum settlement of these two foundation types are satisfied (Bowles 2001). 
Table 2

Parameters of the subsoil

\begin{tabular}{|lllllllll|}
\hline $\begin{array}{l}\text { Soil type } \\
(\text { AS1170) }\end{array}$ & $\boldsymbol{V}_{\boldsymbol{s}}$ & $\begin{array}{l}\text { Unified } \\
(\mathrm{m} / \mathrm{s})\end{array}$ & $\begin{array}{l}\boldsymbol{G}_{\max } \\
\text { classification } \\
(\mathrm{kPa})\end{array}$ & $\begin{array}{l}\text { Poisson's } \\
\text { ratio }\end{array}$ & $\begin{array}{l}\text { Soil } \\
\text { density } \\
\left(\mathbf{k g} / \mathbf{m}^{3}\right)\end{array}$ & $\begin{array}{l}\boldsymbol{c}^{\prime} \\
(\mathrm{kPa})\end{array}$ & $\begin{array}{l}\boldsymbol{\varphi}^{\prime} \\
\text { (degree) }\end{array}$ & $\begin{array}{l}\text { Plastic } \\
\text { Index }\end{array}$ \\
\hline $\mathrm{C}_{\mathrm{e}}$ & 600 & $\mathrm{GM}$ & 623,400 & 0.28 & 1730 & 5 & 40 & - \\
\hline $\mathrm{D}_{\mathrm{e}}$ & 320 & $\mathrm{CL}$ & 177,300 & 0.39 & 1730 & 20 & 19 & 20 \\
\hline $\mathrm{E}_{\mathrm{e}}$ & 150 & $\mathrm{CL}$ & 33,100 & 0.40 & 1470 & 20 & 12 & 15 \\
\hline
\end{tabular}

Table 3

Pile diameters and centre to centre distances

\begin{tabular}{|llll|}
\hline Structures & height-width ratio & Diameter $(\mathrm{m})$ & Centre to centre distance $(\mathrm{m})$ \\
\hline 20-storey & 4 & 1.2 & 4 \\
& 5 & 1.2 & 3 \\
\hline 30 -storey & 4 & 1.2 & 2.6 \\
& 6 & 1.5 & 6 \\
\hline 40-storey & 4 & 1.5 & 5 \\
& 6 & 1.5 & 4 \\
& 5 & 2 & 8 \\
\hline & 6 & 2 & 6 \\
\hline
\end{tabular}

\section{Numerical Model}

This section introduces the modeling method of the structure, foundation, subsoil and contact surface, the setting of boundary conditions and the seismic motion input method in finite element software Abaqus 6.14. In the next section, the direct method will be adopted to study the seismic response of highrise frame-core tube structures with various parameters considering SSI.

\subsection{Structural model}

In order to improve computing efficiency, shell elements S4R are adopted to model shear walls and slabs and beam elements B31 are adopted to model beams and columns. Three dimensional eight-node reduced integration element C3D8R are employed to simulate the basement, base slab and piles (Fig. 1d). 
The damping ratio of RC structures are assumed to be $5 \%$ and damping coefficients ( $a$ and $\beta$ ) are obtained based on the first and second natural frequencies of the structure (Van Nguyen et al. 2017). In addition, elastic-perfectly plastic behaviour is adopted in structural elements and yield stress is specified. The yield stress, $E_{c}$ and density of concrete material are equal to the values introduced in section 2 .

\subsection{Soil model}

The soil element is modeled by solid elements C3D8R and the Mohr-Coulomb failure criterion is employed. To achieve this in Abaqus, cohesion and internal friction angle (Table 2) and the tension cut off option are specified.

In order to take into account the nonlinearity of subsoil, the cyclic shear strain $\left(\gamma_{c}\right)$ depended shear modulus ( $G / G_{\text {max }}$ ) curves (Fig. 4 and 5 ) and damping ratio ( $\xi$ ) curves (Fig. 6 and 7 ) provided by Sun et al. (1998) and Seed et al. (1986) are adopted for cohesive soils $\left(D_{e}\right.$ and $E_{e}$ soil) and cohesionless soils $\left(C_{e}\right.$ soil), respectively. After that, the trial and error were employed to calculate the strain-compatible values of soil damping and shear modulus under four seismic records (Fig. 2 and Table 4). The detailed steps of this process can be found in Tabatabaiefar et al. (2013) and Fatahi and Tabatabaiefar (2014). The soil strain-compatible parameters is presented in Table 5.

Rayleigh damping is adopted to consider the energy losses in the ground soil under the action of earthquakes. In this process, it is very important to select soil frequencies because it determines the damping coefficients $a$ and $\beta$. In this study, the method introduced by Park and Hashash (2003) that the selection of soil frequencies should partially cover the main frequency range of the seismic record is used. Table 5 provides the Rayleigh damping parameters of subsoil calculated by this method.

Table 4

Parameters of seismic records

\begin{tabular}{|c|c|c|c|c|c|c|c|}
\hline Earthquake & Country & Year & $\begin{array}{l}\text { PGA } \\
\text { (g) }\end{array}$ & $\begin{array}{l}\text { Moment } \\
\text { magnitude (R) }\end{array}$ & $\begin{array}{l}\text { Duration } \\
\text { (s) }\end{array}$ & Type & $\begin{array}{l}\text { Hypocentral } \\
\text { distance }(\mathrm{km})\end{array}$ \\
\hline El Centro & USA & 1940 & 0.349 & 6.9 & 56.5 & $\begin{array}{l}\text { Far } \\
\text { field }\end{array}$ & 15.69 \\
\hline Hachinohe & Japan & 1968 & 0.229 & 7.5 & 36.0 & $\begin{array}{l}\text { Far } \\
\text { field }\end{array}$ & 14.1 \\
\hline Kobe & Japan & 1995 & 0.833 & 6.8 & 50.0 & $\begin{array}{l}\text { Near } \\
\text { field }\end{array}$ & 7.4 \\
\hline Northridge & USA & 1994 & 0.843 & 6.7 & 30.0 & $\begin{array}{l}\text { Near } \\
\text { field }\end{array}$ & 9.2 \\
\hline
\end{tabular}


Table 5

Adopted soil strain-compatible parameters and Rayleigh damping parameters

\begin{tabular}{|c|c|c|c|c|}
\hline Soil types & Seismic records & $G / G_{\max }$ & $\xi$ & Damping coefficients \\
\hline \multirow[t]{8}{*}{$\mathrm{E}_{\mathrm{e}}$} & \multirow[t]{2}{*}{ El-Centro } & \multirow[t]{2}{*}{0.57} & \multirow[t]{2}{*}{$11.1 \%$} & $a=0.769$ \\
\hline & & & & $\beta=0.012$ \\
\hline & \multirow[t]{2}{*}{ Hachinohe } & \multirow[t]{2}{*}{0.60} & \multirow[t]{2}{*}{$10.4 \%$} & $a=0.284$ \\
\hline & & & & $\beta=0.024$ \\
\hline & \multirow[t]{2}{*}{ Kobe } & \multirow[t]{2}{*}{0.35} & \multirow[t]{2}{*}{$17.0 \%$} & $a=1.043$ \\
\hline & & & & $\beta=0.021$ \\
\hline & \multirow[t]{2}{*}{ Northridge } & \multirow[t]{2}{*}{0.21} & \multirow[t]{2}{*}{$23.5 \%$} & $a=1.415$ \\
\hline & & & & $\beta=0.029$ \\
\hline \multirow[t]{8}{*}{$D_{e}$} & \multirow[t]{2}{*}{ El-Centro } & \multirow[t]{2}{*}{0.71} & \multirow[t]{2}{*}{$7.8 \%$} & $a=0.5337$ \\
\hline & & & & $\beta=0.0084$ \\
\hline & \multirow[t]{2}{*}{ Hachinohe } & \multirow[t]{2}{*}{0.72} & \multirow[t]{2}{*}{$7.1 \%$} & $a=0.1936$ \\
\hline & & & & $\beta=0.0162$ \\
\hline & \multirow[t]{2}{*}{ Kobe } & \multirow[t]{2}{*}{0.55} & \multirow[t]{2}{*}{$11.7 \%$} & $a=0.7179$ \\
\hline & & & & $\beta=0.0141$ \\
\hline & \multirow[t]{2}{*}{ Northridge } & \multirow[t]{2}{*}{0.46} & \multirow[t]{2}{*}{$13.7 \%$} & $a=0.825$ \\
\hline & & & & $\beta=0.0169$ \\
\hline \multirow[t]{8}{*}{$\mathrm{C}_{\mathrm{e}}$} & \multirow[t]{2}{*}{ El-Centro } & \multirow[t]{2}{*}{0.53} & \multirow[t]{2}{*}{$6.2 \%$} & $a=0.4242$ \\
\hline & & & & $\beta=0.0067$ \\
\hline & \multirow[t]{2}{*}{ Hachinohe } & \multirow[t]{2}{*}{0.53} & \multirow[t]{2}{*}{$6.2 \%$} & $a=0.1691$ \\
\hline & & & & $\beta=0.0142$ \\
\hline & \multirow[t]{2}{*}{ Kobe } & 0.22 & $11.1 \%$ & $a=0.6811$ \\
\hline & & & & $\beta=0.0134$ \\
\hline & Northridge & 0.21 & $11.2 \%$ & $a=0.6744$ \\
\hline & & & & $\beta=0.0138$ \\
\hline
\end{tabular}

\subsection{Contact surface}

Surface to surface contact (standard) in Abaqus is adopted to simulate the interaction between the foundation and surrounding soil during seismic loading. In this process, the master surface is the 
foundation surface, and the slave surface is the soil surface. This is because the mesh sizes of these two surfaces are similar, and the material of foundation is more stiff. Besides, finite sliding formulation and surface-to-surface discretisation method are employed.

The contact interaction property includes two parts: normal direction and tangential direction. In the normal direction, the default relationship between contact pressure and clearance in Abaqus, hard contact, is applied, in which the amount of pressure that can be transmitted between the contact surfaces is not limited; when the contact pressure becomes negative or zero, the two contact surfaces will separate, and contact constraints on the corresponding nodes will be invalid (Van Nguyen et al. 2017). In the tangential direction, penalty friction formulation and contact-pressure-dependent data are adopted to simulate Mohr-Coulomb failure model between the contact surface of foundation and soil.

\subsection{Boundary conditions}

In order to avoid reflection of outward propagating waves on the boundary and capture the recovery ability of the semi-infinite ground, viscous-spring boundary is applied on lateral and bottom surfaces of soil domain. To achieve this goal, independent springs and dampers in one normal and two tangential directions were set on the boundary nodes (Gu et al. 2007), as shown in Fig. 8. The coefficients of the springs $K_{T}$ and $K_{N}$ and coefficients of dampers $C_{T}$ and $C_{N}$ (subscripts $T$ and $\mathrm{N}$ indicate tangential and normal directions, respectively) can be calculated by the characteristics of the surrounding soil as follows:

$K_{T}=\mathrm{a}_{\mathrm{T}} G / R, C_{T}=\rho V_{s}(1)$

$K_{N}=a_{N} G / R, C_{N}=\rho V_{p}(2)$

Where $\mathrm{a}_{\mathrm{T}}, \mathrm{a}_{\mathrm{N}}$ are modified coefficients, $\mathrm{a}_{\mathrm{T}}=0.67, \mathrm{a}_{\mathrm{N}}=1.33$ (Liu et al. 2006); $R$ is the distance between the wave source and boundary nodes; $\rho$ and $G$ are the density and shear modulus of the subsoil, respectively; $V_{s}$ and $V_{p}$ are shear wave velocity and $\mathrm{P}$ wave velocity of the subsoil, respectively.

\subsection{Seismic motion input method}

After the viscous-spring boundary is applied, the artificial boundary node should conform to the free field motion to supply conditions identical to infinite model. Generally, one-dimensional free-field grid is set on the periphery of the model, parallel to the main grid, and connected to the main grid nodes through springs and dampers. However, this method will increase the number of elements, and it is difficult to implement in Abaqus due to the large number of boundary nodes. In this study, the free field motion is transformed into the equivalent node force $F_{b}$ applied on boundary nodes ( $M a$ et al. 2020), and $F_{b}$ comprises three parts: the first two parts is used to compensate the influence of springs and dashpots, and the third part is the free field stress on the boundary:

$\mathrm{F}_{\mathrm{b}}=\left(\mathrm{K}_{\mathrm{b}} \mathrm{u}_{\mathrm{b}}{ }^{\mathrm{ff}}+\mathrm{C}_{\mathrm{b}} \mathrm{v}_{\mathrm{b}}{ }^{\mathrm{ff}}+\sigma_{\mathrm{b}}{ }^{\mathrm{ff}} \mathrm{n}\right) A_{\mathrm{b}}(3)$ 
Where $\mathrm{u}_{\mathrm{b}}{ }^{\mathrm{ff}}$ and $\mathrm{v}_{\mathrm{b}}{ }^{\mathrm{ff}}$ are free field displacement and velocity vectors at boundary nodes, respectively; $\sigma_{b}{ }^{\mathrm{ff}}$ is the free field stress tensor; $\mathrm{K}_{\mathrm{b}}$ and $\mathrm{C}_{\mathrm{b}}$ are coefficient vectors of springs and dashpots on the boundary, respectively. $A_{b}$ is the influencing area of boundary nodes and $\mathrm{n}$ is the cosine vector of the normal direction outside the boundary. By compiling a simple program in MATLAB software, the amplitudes of $F_{b}$ in one normal direction and two tangential directions of each boundary node were obtained.

The validity and accuracy of the numerical model have been verified by comparison between experimental shaking table test results and numerical outputs by Zhang and Far (2001). After that, the seismic response of high-rise frame-core tube structures with various parameters considering SSI was numerically studied and the results can be found in Section 4 .

\section{Results And Discussions}

\subsection{Maximum Lateral Deflection}

Figure $9,10,11,12,13,14,15,16$ and 17 show the maximum lateral deflections of 20-, 30- and 40-storey structures with different height-width ratios, foundation types and soil types under the action of four seismic records. Compared with fixed base counterparts, almost all the maximum lateral deflections of flexible base structures have been amplified, regardless of the structural height, height-width ratios, foundation and soil types. This is because the degree of freedom of the soil-structure system increases after considering SSI and the natural period is prolonged, and the displacement response spectrum curve generally increases with the increase of the natural period of the system. As a result, the amplification of the displacement response of high-rise buildings was observed.

It is also can be seen that when the superstructure parameters are the same, the maximum lateral deflections of piled foundation structures only change slightly with the type of soil, but the variation of displacement response of classical compensated foundation structures is relatively dramatic, especially under the action of far-field earthquakes. This means that the end bearing pile foundation supported structures is less susceptible to the type of soil.

In addition, the maximum lateral deflections of piled foundation structures are not necessarily smaller than that of classical compensated foundation structures. For example, under the action of far-field earthquakes, the deformation of piled foundation structures (with little difference between each other) is usually smaller than that of classical compensated foundation structures resting on the type $E_{e}$ soil; however, under the action of near-field earthquakes, the deformation of piled foundation structures does not decrease obviously in comparison to classical compensated foundation structures. It is also worth pointing out that under the action of far-field earthquakes, with the soil type changes from $\mathrm{C}_{e}$ to $\mathrm{E}_{e}$, the maximum lateral deflections of structures increase gradually, especially for classical compensated foundation structures. In contrast, under the action of the near-filed earthquakes, the deformation of structures usually decreases with the subsoil modulus decreases. 
The effects of height-width ratio on the maximum lateral deflection is complex. On one hand, the increase in the width of buildings can increase the stability of structures and decrease the foundation rotation. On the other hand, the increase in the width means the increase in the mass of buildings, which will increase the inertial force and structural distortion in seismic excitations. Therefore, the maximum lateral deflection follows different patterns as the height-width ratio changes.

Figure 17 Maximum lateral deflections of 40-storey structure (height-width ratio=4) with various foundation types and subsoil types under different seismic records: (a) El Centro earthquake (b) Hachinohe earthquake (c) Kobe earthquake (d) Northridge earthquake 4.2 Foundation Rocking

Different from fixed base structures, lateral deflections of structures modeled with soil include rocking and distortion components (Kramer 1996). Table 6, 7 and 8 record the proportion of the foundation rocking induced lateral deflection in the total deflection of the top floor of 20-, 30- and 40-storey structures, respectively. The restriction of structure width on the rotation of the structure is not significant, whereas the soil type can considerably restrain the foundation rocking, and this phenomenon is more obvious in classical compensated foundation supported models. Similarly, the pile foundation can also effectively restrain the rotation of the foundation. For classical compensated foundation structures founded on $\mathrm{E}_{\mathrm{e}}$ soils, the foundation rotation induced displacement accounts for an average of more than $90 \%$ of the total displacement, which means buildings are more likely to rotate overall. In contrast, this value is only $17.03 \%$ in the case of piled foundation models.

However, as observed in Section 4.1, although the end-bearing piled foundation can effectively reduce the foundation rocking, the maximum lateral deflections of piled foundation structures is not always smaller than that of the classical compensated foundation structures. 
Table 6

The proportion of foundation rocking induced lateral deflection of 20-storey structures (\%)

\begin{tabular}{|c|c|c|c|c|c|c|c|}
\hline \multirow[t]{2}{*}{$\begin{array}{l}\text { Height-width } \\
\text { ratio }\end{array}$} & \multirow[t]{2}{*}{$\begin{array}{l}\text { Earthquake } \\
\text { record }\end{array}$} & \multicolumn{3}{|c|}{ Piled foundation model } & \multicolumn{3}{|c|}{$\begin{array}{l}\text { Compensated foundation } \\
\text { model }\end{array}$} \\
\hline & & $\begin{array}{l}\mathrm{E}_{\mathrm{e}} \\
\text { soil }\end{array}$ & $\begin{array}{l}D_{e} \\
\text { soil }\end{array}$ & $\begin{array}{l}\mathrm{C}_{\mathrm{e}} \\
\text { soil }\end{array}$ & $E_{e}$ soil & $D_{e}$ soil & $C_{e}$ soil \\
\hline \multirow[t]{4}{*}{6} & El Centro & 29.29 & 26.73 & 13.16 & 94.85 & 82.18 & 31.50 \\
\hline & Hachinohe & 30.97 & 27.62 & 15.77 & 96.06 & 85.98 & 14.74 \\
\hline & Kobe & 28.04 & 24.59 & 12.19 & 81.30 & 45.90 & 42.63 \\
\hline & Northridge & 28.90 & 24.42 & 10.60 & 95.83 & 81.16 & 47.21 \\
\hline \multirow[t]{4}{*}{5} & El Centro & 28.43 & 26.83 & 10.17 & 97.62 & 83.44 & 33.13 \\
\hline & Hachinohe & 29.65 & 21.35 & 13.94 & 94.67 & 86.87 & 18.33 \\
\hline & Kobe & 28.29 & 24.49 & 11.53 & 87.74 & 76.21 & 46.59 \\
\hline & Northridge & 30.79 & 24.35 & 10.27 & 92.52 & 83.22 & 52.63 \\
\hline \multirow[t]{4}{*}{4} & El Centro & 24.78 & 23.79 & 13.51 & 94.57 & 77.76 & 29.00 \\
\hline & Hachinohe & 25.47 & 23.37 & 10.51 & 92.99 & 34.69 & 28.96 \\
\hline & Kobe & 26.95 & 22.19 & 12.25 & 89.52 & 85.45 & 49.06 \\
\hline & Northridge & 28.41 & 21.78 & 10.58 & 92.30 & 88.93 & 59.07 \\
\hline Average value & & 28.33 & 24.28 & 12.04 & 92.50 & 75.99 & 37.74 \\
\hline
\end{tabular}


Table 7

The proportion of foundation rocking induced lateral deflection of 30-storey structures (\%)

\begin{tabular}{|c|c|c|c|c|c|c|c|}
\hline \multirow[t]{2}{*}{$\begin{array}{l}\text { Height-width } \\
\text { ratio }\end{array}$} & \multirow[t]{2}{*}{$\begin{array}{l}\text { Earthquake } \\
\text { record }\end{array}$} & \multicolumn{3}{|c|}{ Piled foundation model } & \multicolumn{3}{|c|}{$\begin{array}{l}\text { Compensated foundation } \\
\text { model }\end{array}$} \\
\hline & & $\begin{array}{l}\mathrm{E}_{\mathrm{e}} \\
\text { soil }\end{array}$ & $\begin{array}{l}D_{e} \\
\text { soil }\end{array}$ & $\begin{array}{l}\mathrm{C}_{\mathrm{e}} \\
\text { soil }\end{array}$ & $E_{e}$ soil & $D_{e}$ soil & $C_{e}$ soil \\
\hline \multirow[t]{4}{*}{6} & El Centro & 22.18 & 23.05 & 12.68 & 93.66 & 87.91 & 32.03 \\
\hline & Hachinohe & 24.60 & 23.23 & 12.51 & 96.36 & 85.64 & 64.57 \\
\hline & Kobe & 24.08 & 22.65 & 12.08 & 74.36 & 57.21 & 32.25 \\
\hline & Northridge & 26.08 & 24.71 & 12.65 & 84.72 & 94.51 & 57.75 \\
\hline \multirow[t]{4}{*}{5} & El Centro & 17.09 & 17.63 & 9.35 & 92.01 & 85.52 & 34.03 \\
\hline & Hachinohe & 18.46 & 17.03 & 10.84 & 92.07 & 78.83 & 64.75 \\
\hline & Kobe & 17.42 & 18.26 & 9.40 & 73.31 & 58.93 & 30.58 \\
\hline & Northridge & 17.73 & 15.95 & 7.47 & 97.14 & 93.88 & 63.68 \\
\hline \multirow[t]{4}{*}{4} & El Centro & 16.77 & 18.03 & 7.92 & 91.49 & 83.94 & 47.07 \\
\hline & Hachinohe & 18.84 & 16.83 & 15.98 & 90.29 & 73.60 & 64.77 \\
\hline & Kobe & 17.65 & 14.54 & 4.50 & 96.84 & 72.44 & 20.77 \\
\hline & Northridge & 18.29 & 15.69 & 5.92 & 96.67 & 89.11 & 63.27 \\
\hline Average value & & 19.94 & 18.97 & 10.11 & 89.91 & 80.13 & 47.96 \\
\hline
\end{tabular}


Table 8

The proportion of foundation rocking induced lateral deflection of 40-storey structures (\%)

\begin{tabular}{|c|c|c|c|c|c|c|c|}
\hline \multirow[t]{2}{*}{$\begin{array}{l}\text { Height-width } \\
\text { ratio }\end{array}$} & \multirow[t]{2}{*}{$\begin{array}{l}\text { Earthquake } \\
\text { record }\end{array}$} & \multicolumn{3}{|c|}{ Piled foundation model } & \multicolumn{3}{|c|}{$\begin{array}{l}\text { Compensated foundation } \\
\text { model }\end{array}$} \\
\hline & & $\begin{array}{l}\mathrm{E}_{\mathrm{e}} \\
\text { soil }\end{array}$ & $\begin{array}{l}D_{e} \\
\text { soil }\end{array}$ & $\begin{array}{l}\mathrm{C}_{\mathrm{e}} \\
\text { soil }\end{array}$ & $E_{e}$ soil & $D_{e}$ soil & $C_{e}$ soil \\
\hline \multirow[t]{4}{*}{6} & El Centro & 18.94 & 19.60 & 9.09 & 95.27 & 81.73 & 37.20 \\
\hline & Hachinohe & 16.80 & 15.88 & 15.63 & 92.36 & 85.32 & 61.86 \\
\hline & Kobe & 14.14 & 16.45 & 4.23 & 98.08 & 49.88 & 15.18 \\
\hline & Northridge & 14.65 & 15.33 & 13.39 & 91.59 & 77.78 & 64.56 \\
\hline \multirow[t]{4}{*}{5} & El Centro & 17.58 & 18.44 & 7.51 & 88.35 & 77.43 & 50.23 \\
\hline & Hachinohe & 16.12 & 14.83 & 14.75 & 90.26 & 80.03 & 60.37 \\
\hline & Kobe & 13.63 & 14.28 & 7.33 & 98.19 & 55.67 & 41.26 \\
\hline & Northridge & 15.65 & 14.32 & 12.44 & 90.86 & 80.92 & 66.97 \\
\hline \multirow[t]{4}{*}{4} & El Centro & 13.57 & 14.64 & 9.02 & 89.03 & 79.13 & 63.17 \\
\hline & Hachinohe & 13.26 & 12.85 & 11.87 & 87.74 & 67.26 & 61.39 \\
\hline & Kobe & 11.31 & 11.19 & 3.38 & 94.30 & 58.43 & 15.65 \\
\hline & Northridge & 12.47 & 10.67 & 10.41 & 91.00 & 84.90 & 43.69 \\
\hline Average value & & 14.84 & 14.88 & 9.92 & 92.26 & 73.21 & 48.46 \\
\hline
\end{tabular}

4.3 Inter-storey Drifts

The inter-storey drifts of 20-, 30- and 40-storey structures with different height-width ratios, foundation types and soil types is shown in Fig. 18, 19, 20, 21, 22, 23, 24, 25 and 26. The inter-storey drifts were obtained adopting the method based on AS1170-4 (2007). Similar to lateral deflections, inter-storey drifts of almost all flexible base cases have increased and the maximum value of many near-field earthquake cases and several far-filed earthquake cases have exceeded 1.5\%, which means the performance levels were changed from life safe towards near-collapse or collapse level after SSI is taken into account (BSSC 1997). In classical compensated foundation models, the inter-storey drifts usually present an approximately vertical line, indicating that inter-storey drifts only change slightly with the structural height. In other words, the foundation rotation induced lateral deflection accounts for a large part of the total maximum lateral deflection in the classical compensated foundation models. Moreover, compared with classical compensated foundation cases, inter-storey drifts of piled structures with the same height, height-width ratio and seismic record do not change significantly with the soil type. Besides, it is worth noting that a considerable increase of inter-storey drifts is found in structures resting on $\mathrm{C}_{\mathrm{e}}$ soil under 
near-field earthquakes and structures with compensated foundation resting on $E_{e}$ soil under far-field earthquakes. This is related to the difference between the shape of response spectra of near and far earthquakes.

Figure 26 Inter-storey drifts of 40-storey structure (height-width ratio=4) with various foundation types and subsoil types under different seismic records: (a) El Centro earthquake (b) Hachinohe earthquake (c) Kobe earthquake (d) Northridge earthquake

\subsection{Base Shear}

Table 9, 10 and 11 compare the base shear of flexible base cases () and fixed base cases $(V)$. The ratios $/ V$ are not always less than 1 , which means the base shear of the structure may increase or decrease after considering SSI, depending on the foundation type and the soil type. For example, the base shears of the classical compensated foundation structures constructed on soft soils (type $E_{e}$ and $D_{e}$ ) are usually less than that of fixed base counterparts, while the base shears of the classical compensated foundation models resting on $\mathrm{C}_{\mathrm{e}}$ soil and the piled foundation models are generally amplified. That means increasing the stiffness of the foundation and subsoil can absorb more seismic energy, making the traditional assumption that SSI can always reduce the seismic demand of the structure invalid. This result is consistent with Van Nguyen (2017). Therefore, although the piled foundation can reduce the foundation rocking, it will probably increase the seismic shear force and in turn increase the lateral displacement of the structure, which also explains why the deformation of the piled foundation model is not necessarily less than that of the classical compensated foundation model in Sections 4.1 and 4.3. In addition, although the absolute value of the base shear increases with the increase of the height-width ratio, the change of height-width ratio will not exert a critical impact on the relative value of the base shear $(/ V)$. 
Table 9

Base shear ratio of 20-storey structures

\begin{tabular}{|c|c|c|c|c|c|c|c|c|}
\hline \multirow[t]{2}{*}{$\begin{array}{l}\text { Height-width } \\
\text { ratio }\end{array}$} & \multirow[t]{2}{*}{$\begin{array}{l}\text { Earthquake } \\
\text { record }\end{array}$} & \multirow[t]{2}{*}{$\begin{array}{l}V \\
(\mathrm{MN})\end{array}$} & \multicolumn{3}{|c|}{$\begin{array}{l}\text { Piled foundation } \\
\text { model / } V\end{array}$} & \multicolumn{3}{|c|}{$\begin{array}{l}\text { Compensated foundation } \\
\text { model / } V\end{array}$} \\
\hline & & & $\begin{array}{l}E_{e} \\
\text { soil }\end{array}$ & $\begin{array}{l}D_{e} \\
\text { soil }\end{array}$ & $\begin{array}{l}\mathrm{C}_{\mathrm{e}} \\
\text { soil }\end{array}$ & $E_{e}$ soil & $D_{e}$ soil & $C_{e}$ soil \\
\hline \multirow[t]{4}{*}{6} & El Centro & 6.38 & 1.29 & 1.25 & 1.50 & 0.60 & 1.00 & 1.20 \\
\hline & Hachinohe & 6.21 & 1.14 & 1.68 & 1.92 & 0.57 & 0.89 & 1.75 \\
\hline & Kobe & 18.17 & 1.21 & 1.58 & 1.91 & 0.45 & 1.21 & 1.59 \\
\hline & Northridge & 21.14 & 1.05 & 1.47 & 2.11 & 0.24 & 0.59 & 1.67 \\
\hline \multirow[t]{4}{*}{5} & El Centro & 8.73 & 1.17 & 1.21 & 1.63 & 0.44 & 0.86 & 1.06 \\
\hline & Hachinohe & 7.80 & 1.06 & 1.63 & 2.13 & 0.53 & 0.89 & 1.49 \\
\hline & Kobe & 20.30 & 1.31 & 1.74 & 2.02 & 0.43 & 0.78 & 1.67 \\
\hline & Northridge & 22.96 & 1.17 & 1.57 & 2.51 & 0.24 & 0.56 & 1.92 \\
\hline \multirow[t]{4}{*}{4} & El Centro & 11.71 & 1.17 & 1.33 & 2.00 & 0.44 & 0.83 & 1.31 \\
\hline & Hachinohe & 12.50 & 0.90 & 1.34 & 1.64 & 0.48 & 1.10 & 1.35 \\
\hline & Kobe & 31.83 & 1.08 & 1.44 & 1.72 & 0.28 & 0.54 & 1.50 \\
\hline & Northridge & 33.42 & 1.04 & 1.39 & 2.40 & 0.26 & 0.46 & 1.62 \\
\hline Average value & & & 1.13 & 1.47 & 1.96 & 0.41 & 0.81 & 1.51 \\
\hline
\end{tabular}


Table 10

Base shear ratio of 30-storey structures

\begin{tabular}{|c|c|c|c|c|c|c|c|c|}
\hline \multirow[t]{2}{*}{$\begin{array}{l}\text { Height-width } \\
\text { ratio }\end{array}$} & \multirow[t]{2}{*}{$\begin{array}{l}\text { Earthquake } \\
\text { record }\end{array}$} & \multirow[t]{2}{*}{$\begin{array}{l}V \\
(\mathrm{MN})\end{array}$} & \multicolumn{3}{|c|}{$\begin{array}{l}\text { Piled foundation } \\
\text { model / } V\end{array}$} & \multicolumn{3}{|c|}{$\begin{array}{l}\text { Compensated foundation } \\
\text { model / } V\end{array}$} \\
\hline & & & $\begin{array}{l}\mathrm{E}_{\mathrm{e}} \\
\text { soil }\end{array}$ & $\begin{array}{l}D_{e} \\
\text { soil }\end{array}$ & $\begin{array}{l}\mathrm{C}_{\mathrm{e}} \\
\text { soil }\end{array}$ & $E_{e}$ soil & $D_{e}$ soil & $C_{e}$ soil \\
\hline \multirow[t]{4}{*}{6} & El Centro & 17.46 & 1.21 & 1.47 & 2.05 & 0.59 & 1.12 & 1.73 \\
\hline & Hachinohe & 11.96 & 2.07 & 2.09 & 2.24 & 0.55 & 0.76 & 1.88 \\
\hline & Kobe & 41.44 & 0.57 & 1.23 & 1.79 & 0.32 & 0.80 & 1.20 \\
\hline & Northridge & 41.90 & 0.80 & 1.01 & 1.55 & 0.29 & 0.49 & 0.75 \\
\hline \multirow[t]{4}{*}{5} & El Centro & 25.64 & 0.82 & 1.25 & 1.63 & 0.43 & 0.91 & 1.49 \\
\hline & Hachinohe & 15.11 & 1.85 & 2.00 & 1.88 & 0.58 & 0.75 & 1.77 \\
\hline & Kobe & 48.48 & 0.65 & 1.28 & 2.22 & 0.27 & 0.86 & 1.64 \\
\hline & Northridge & 63.98 & 0.71 & 0.89 & 1.48 & 0.18 & 0.39 & 0.88 \\
\hline \multirow[t]{4}{*}{4} & El Centro & 26.68 & 1.22 & 1.43 & 2.19 & 0.39 & 1.03 & 2.05 \\
\hline & Hachinohe & 21.65 & 1.75 & 1.83 & 1.96 & 0.52 & 0.97 & 1.84 \\
\hline & Kobe & 68.79 & 0.58 & 1.08 & 2.43 & 0.19 & 0.80 & 2.08 \\
\hline & Northridge & 87.06 & 0.62 & 0.83 & 1.67 & 0.15 & 0.37 & 1.22 \\
\hline Average value & & & 1.07 & 1.37 & 1.92 & 0.37 & 0.77 & 1.54 \\
\hline
\end{tabular}


Base shear ratio of 40-storey structures

\begin{tabular}{|c|c|c|c|c|c|c|c|c|}
\hline \multirow[t]{2}{*}{$\begin{array}{l}\text { Height-width } \\
\text { ratio }\end{array}$} & \multirow[t]{2}{*}{$\begin{array}{l}\text { Earthquake } \\
\text { record }\end{array}$} & \multirow[t]{2}{*}{$\begin{array}{l}V \\
(\mathrm{MN})\end{array}$} & \multicolumn{3}{|c|}{$\begin{array}{l}\text { Piled foundation } \\
\text { model / } V\end{array}$} & \multicolumn{3}{|c|}{$\begin{array}{l}\text { Compensated foundation } \\
\text { model / } V\end{array}$} \\
\hline & & & $\begin{array}{l}E_{e} \\
\text { soil }\end{array}$ & $\begin{array}{l}D_{e} \\
\text { soil }\end{array}$ & $\begin{array}{l}\mathrm{C}_{\mathrm{e}} \\
\text { soil }\end{array}$ & $E_{e}$ soil & $D_{e}$ soil & $C_{e}$ soil \\
\hline \multirow[t]{4}{*}{6} & El Centro & 31.35 & 1.02 & 1.26 & 1.74 & 0.45 & 0.92 & 1.44 \\
\hline & Hachinohe & 31.22 & 0.99 & 1.21 & 1.51 & 0.50 & 0.66 & 1.47 \\
\hline & Kobe & 71.82 & 0.58 & 1.25 & 2.03 & 0.30 & 1.07 & 1.91 \\
\hline & Northridge & 76.87 & 0.73 & 0.93 & 1.38 & 0.24 & 0.57 & 0.99 \\
\hline \multirow[t]{4}{*}{5} & El Centro & 64.94 & 0.58 & 0.80 & 1.19 & 0.23 & 0.50 & 0.93 \\
\hline & Hachinohe & 40.57 & 1.00 & 1.08 & 1.25 & 0.41 & 0.65 & 1.12 \\
\hline & Kobe & 91.76 & 0.46 & 1.06 & 2.32 & 0.21 & 0.98 & 1.97 \\
\hline & Northridge & 84.50 & 0.68 & 0.95 & 1.74 & 0.22 & 0.62 & 1.16 \\
\hline \multirow[t]{4}{*}{4} & El Centro & 78.73 & 0.59 & 0.94 & 1.67 & 0.16 & 0.52 & 1.29 \\
\hline & Hachinohe & 57.23 & 1.00 & 1.21 & 1.51 & 0.31 & 0.60 & 1.45 \\
\hline & Kobe & 112.27 & 0.34 & 0.91 & 2.67 & 0.16 & 0.84 & 2.25 \\
\hline & Northridge & 100.45 & 0.76 & 0.94 & 1.91 & 0.18 & 0.64 & 1.74 \\
\hline Average value & & & 0.73 & 1.05 & 1.74 & 0.28 & 0.71 & 1.48 \\
\hline
\end{tabular}

\section{Conclusions}

In order to investigate the seismic response of the high rise frame-core tube structure considering SSI, 20-, 30- and 40-storey building models with different height-width ratios, foundation types and soil types were established using Abaqus software. The numerical simulation results including maximum lateral deflections, foundation rocking, inter-storey drifts and base shear of structures with different influencing factors are discussed and compared. The following conclusions can be draw:

- Compared to fixed base cases, the maximum lateral deflections and the inter-storey drifts of almost all structures modelled with subsoil as flexible base models are amplified to different extent, regardless of height width ratios, foundation types and soil types.

- The maximum inter-storey drifts of many near-field earthquake cases and several far-filed earthquake cases have exceeded $1.5 \%$, which means the performance levels of structures have been 
changed after considering SSI. As a consequence, conventional design procedures excluding SSI may not be adequate to guarantee the structural safety of high-rise frame-core tube structures.

- The piled foundation can effectively reduce the foundation rocking compared with classical compensated foundation. However, the maximum lateral deflections of piled foundation models are the largest in many cases, especially under the action of near-field earthquakes. The reason is that the shear forces of piled foundation structures is generally larger than that of compensated foundation structures and fixed base structures.

- When the superstructure parameters are the same, the type of soil has minor effects on the deformation of the pile foundation structures, but it has dramatic effects on classical compensated foundation structures, especially under the action of far-field earthquakes. In other words, the seismic performance of piled foundation structures is less susceptible to the type of soil.

- The stiff soil can considerably restrain the foundation rocking, and this phenomenon is more obvious in classical compensated foundation supported models. For classical compensated foundation structures constructed on soft soils, the foundation rocking induced lateral deflection accounts for a large proportion of the total lateral deflection.

- The base shear of the structure may increase or decrease after considering SSI, depending on the foundation type and the soil type. As a result, blindly increasing the stiffness of the foundation and subsoil may absorb more seismic energy, making the structure neither safe nor economical.

- Although the absolute value of the base shear increases with the increase of the structural heightwidth ratio, the change of the height-width ratio will not exert a significant impact on the relative value of the base shear $(/ V)$.

\section{Declarations}

\section{Statements and Declarations}

The authors declare that no funds, grants, or other support were received during the preparation of this manuscript.

The authors have no relevant financial or non-financial interests to disclose.

\section{References}

Al Agha W, Almorad WA, Umamaheswari N, Alhelwani A (2021) Study the seismic response of reinforced concrete high-rise building with dual framed-shear wall system considering the effect of soil structure interaction. Mater Today: Proceedings 43:2182-2188

Anand V, Satish Kumar SR (2018) Seismic soil-structure interaction: a state-of-the-art review. Structures 16:317-326 
AS1170.4 (2007) Structural design actions: part 4: earthquake actions in Australia. Australian standards, Sydney

AS3600 (2018) Concrete structures. Australian standards, Sydney

Bowles JE (2001) Foundation analysis and design, 5th edn. McGraw-Hill International, New York

Building Seismic Safety Council (BSSC) (1997) NEHRP guidelines for the seismic rehabilitation of buildings. 1997 edition, Part 1: Provisions and Part 2: Commentary. FEMA 273/274, FEMA, Washington, DC

El Ganainy H, El Naggar MH (2009) Seismic performance of three-dimensional frame structures with underground stories. Soil Dyn Earthq Eng 29:1249-1261

Far H, Flint D (2017) Significance of using isolated footing technique for residential construction on expansive soils. Front Struct Civ Eng 11(1):123-129

Far H (2019a) Dynamic behaviour of unbraced steel frames resting on soft ground. Steel Construction 12(2):135-140

Far H (2019b) Advanced computation methods for soil structure interaction analysis of structures resting on soft soils. Int J Geotech Eng 13(4):352-359

Fatahi B, Tabatabaiefar HR (2014) Effects of soil plasticity on seismic performance of mid-rise building frames resting on soft soils. Adv Struct Eng 17(10):1387-1402

Gao L, Fang E, Qian J (2005) Conceptual design of high-rise building structure. China Planning Press, Beijing

GB50011 (2010) Code for seismic design of buildings. China Architecture and Building Press, Beijing

Gu Y, Liu JB, Du YX (2007) 3D consistent viscous-spring artificial boundary and viscous-spring boundary element. Engineering Mechanics 24(12):31-37

Guin J, Banerjee PK (1998) Coupled soil-pile-structure interaction analysis under seismic excitation. J Struct Eng 124:434-444

Hokmabadi AS, Fatahi B, Samali B (2014) Assessment of soil-pile-structure interaction influencing seismic response of mid-rise buildings sitting on floating pile foundations. Comput Geotech 55:172-186

IBC (2012) International Building Code. International Code Council (ICC)

Kramer SL (1996) Geotechnical Earthquake Engineering, Prentice Hall, Upper Saddle River. 
Liu JB, Du YX, Du XL, Wang ZY, Wu J (2006) 3D viscous-spring artificial boundary in time domain. Earthq Eng Eng Vib 5(1):93-102

Ma SJ, Chi MJ, Chen HJ, Chen S (2020) Implementation of viscous-spring boundary in ABAQUS and comparative study on seismic motion input methods. Chinese Journal of Rock Mechanics and Engineering 39(7):1445-1457

Mylonakis G, Gazetas G (2000) Seismic soil-structure interaction: beneficial or detrimental? J Earthq Eng 4:377-401

National Building Code of Canada (NBCC) (2010) NRC Institute for Research in Construction, Canada NZS1170.5 (2007) Structural design actions-part 5: earthquake actions-New Zealand, New Zealand Standards, Wellington

Park D, Hashash YMA (2003) Soil damping formulation in nonlinear time domain site response analysis. J Earthquake Eng 8(2):249-274

Seed HB, Murarka R, Lysmer J, Idriss IM (1976) Relationships of maximum acceleration, maximum velocity, distance from source, and local site conditions for moderately strong earthquakes. B Seismol Soc Am 66(4):1323-1342

Seed HB, Wong R, Idriss IM, Tokimatsu K (1986) Moduli and damping factors for dynamic analysis of cohesionless soil. Int J Geotech Eng 112(11):1016-1032

Sharma N, Dasgupta K, Dey A (2018) A state-of-the-art review on seismic SSI studies on building structures. Innov Infrastruct So 3(22):1-16

Sun JI, Golesorkhi R, Seed B (1998) Dynamic module and damping ratios for cohesive soils. Earthquake Engineering Research Centre, Report No. UCB/EERC-88/15, University of California, Berkeley

Tabatabaiefar HR (2012) Determining seismic response of mid-rise building frames considering dynamic soil-structure interaction. Dissertation, University of Technology Sydney

Tabatabaiefar HR, Fatahi B, Samali B (2013) Seismic behaviour of building frames considering dynamic soil-structure interaction. Int J Geomech 13(4):409-420

Tabatabaiefar HR, Fatahi B (2014) Idealisation of soil-structure system to determine inelastic seismic response of mid-rise building frames. Soil Dyn Earthq Eng 66:339-351

Tabatabaiefar HR (2016) Detail design and construction procedure of laminar soil containers for experimental shaking table tests. Int J Geotech Eng 10(4):328-336

Tabatabaiefar HR, Clifton T (2016) Significance of considering soil-structure interaction effects on seismic design of unbraced building frames resting on soft soils. Aust Geomech J 51(1):55-64 
Van Nguyen Q, Fatahi B, Hokmabadi AS (2017) Influence of size and load-bearing mechanism of piles on seismic performance of buildings considering soil-pile-structure interaction. Int $\mathrm{J}$ Geomech 17(7):04017007

Wolf JP (1985) Dynamic soil-structure interaction. Prentice-Hall, Englewood Cliffs

Wolf JP, Deeks AJ (2004) Foundation vibration analysis: a strength of-materials approach. Elsevier, Oxford

Yashinsky M (1998) The Loma Prieta California, earthquake of October 17, 1989 - highway systems. Professional paper 1552-B. U.S. Geological Survey

Zhang XF, Far H (2021) Effects of dynamic soil-structure interaction on seismic behaviour of high-rise buildings. B Earthq Eng. https://doi.org/10.1007/s10518-021-01176-z

\section{Figures}




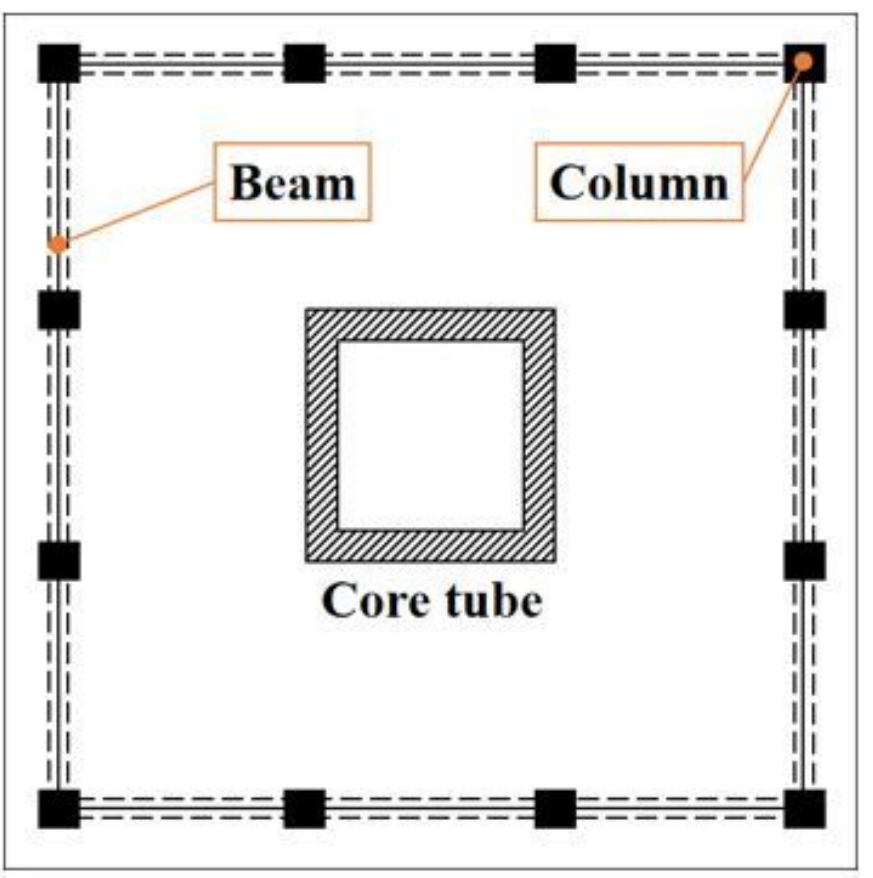

(a)

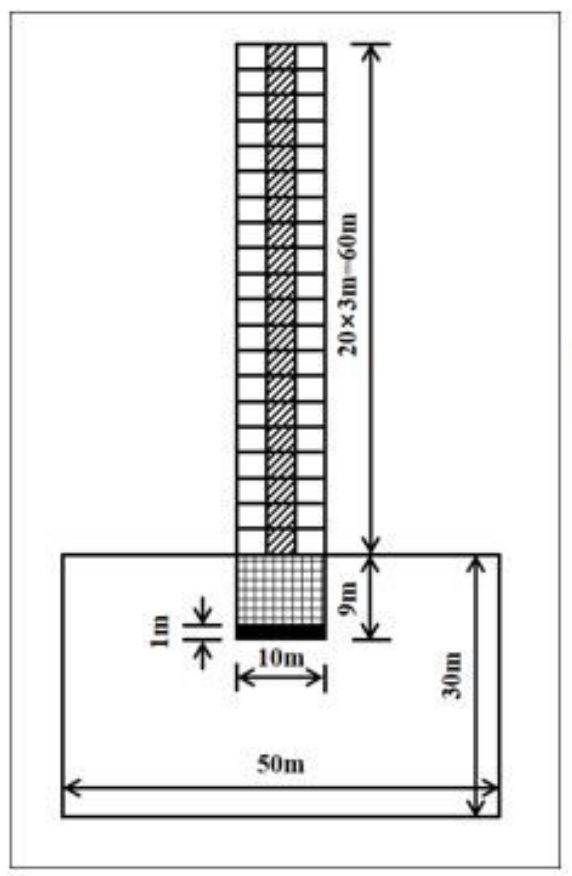

(c)

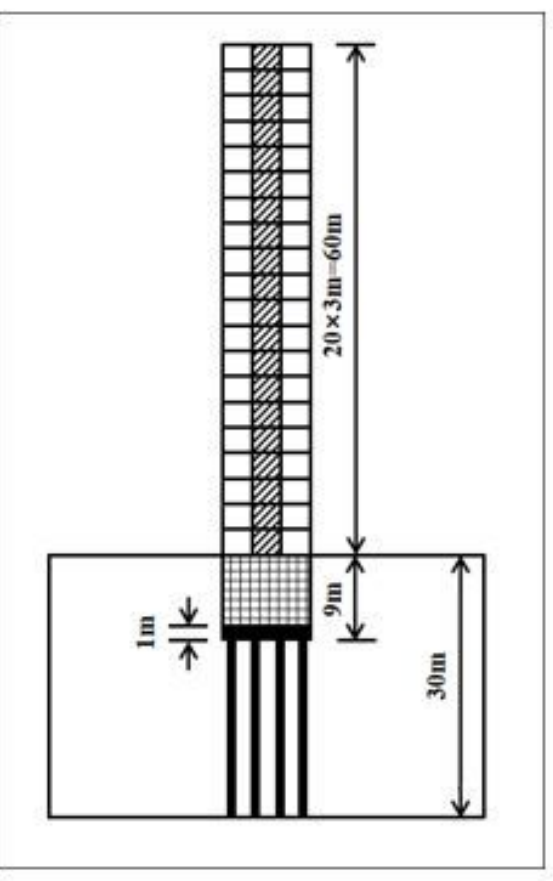

(b)

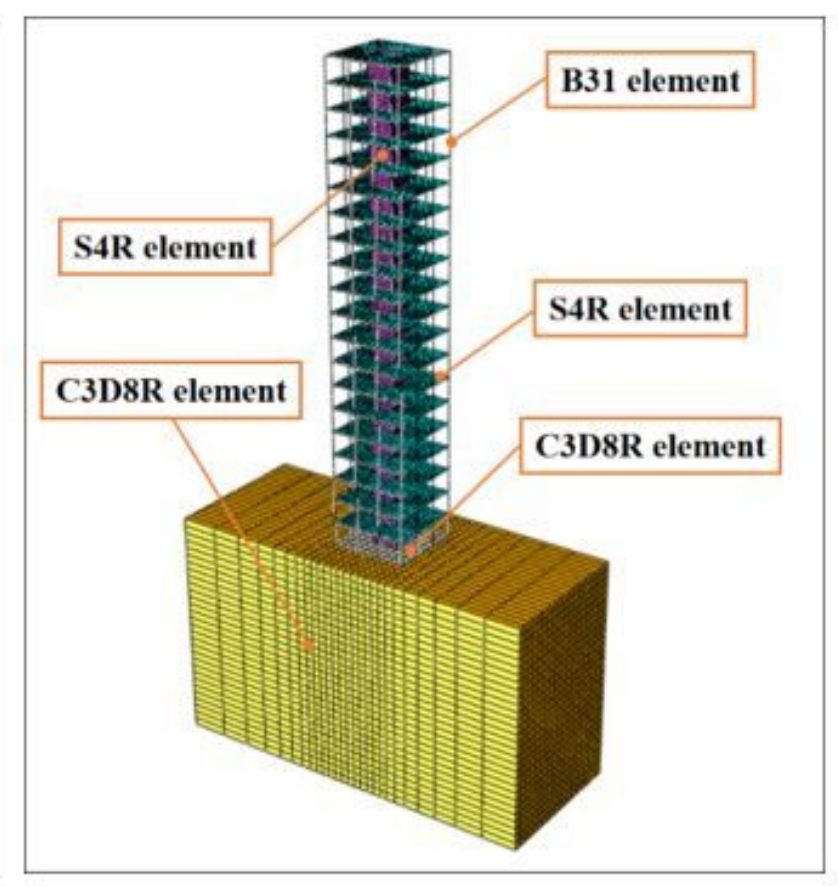

(d)

\section{Figure 1}

Characteristics of frame-core tube structure (a) plan view of standard storey (b) 20-storey frame-core tube structure with end bearing piled foundation (height-width ratio=6) (c) 20-storey frame-core tube structure with classical compensated foundation (height-width ratio=6) $(d)$ the finite-element model 


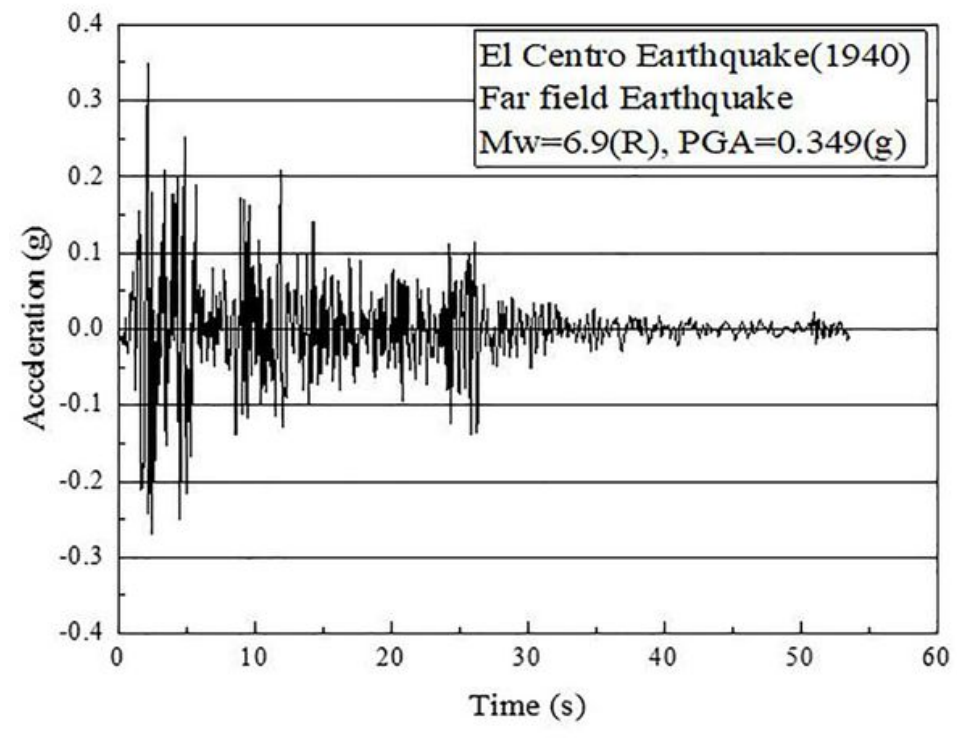

(a)

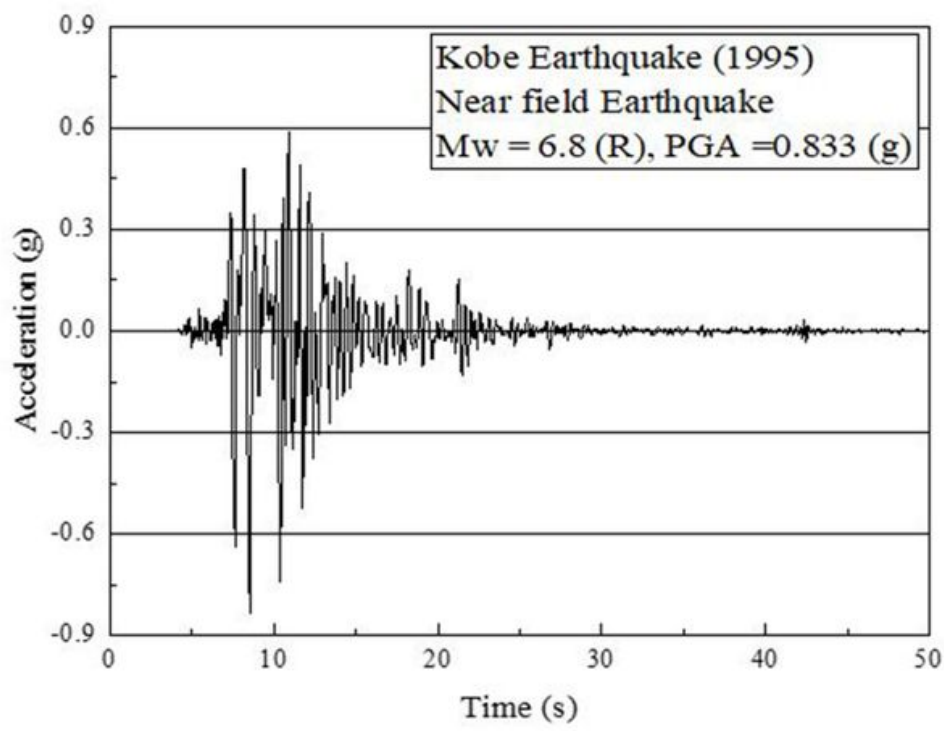

(c)

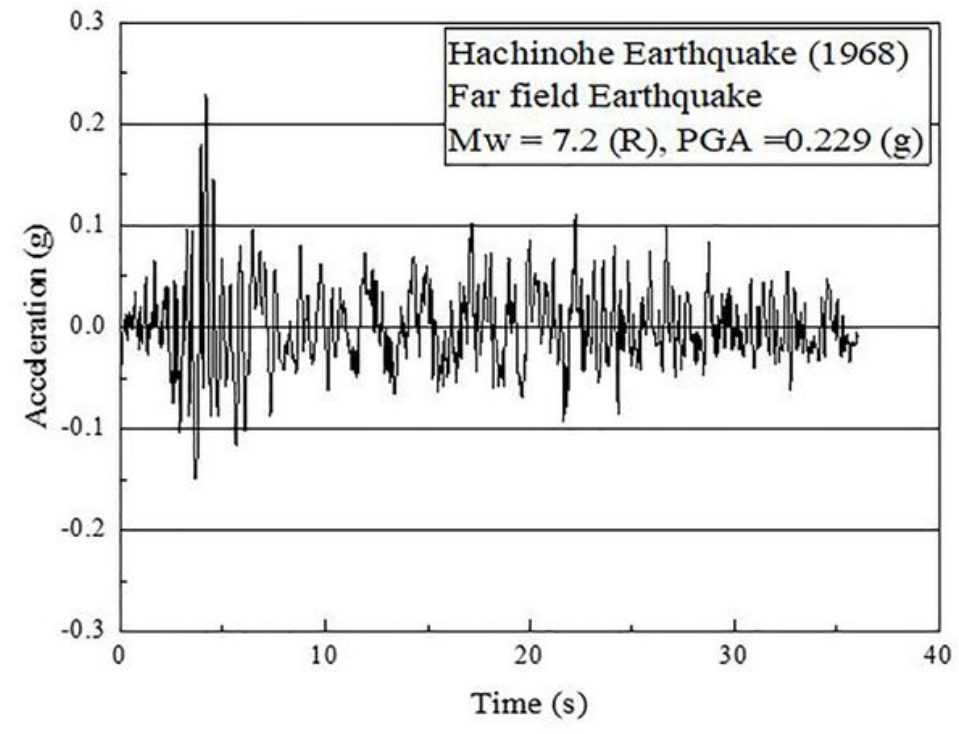

(b)

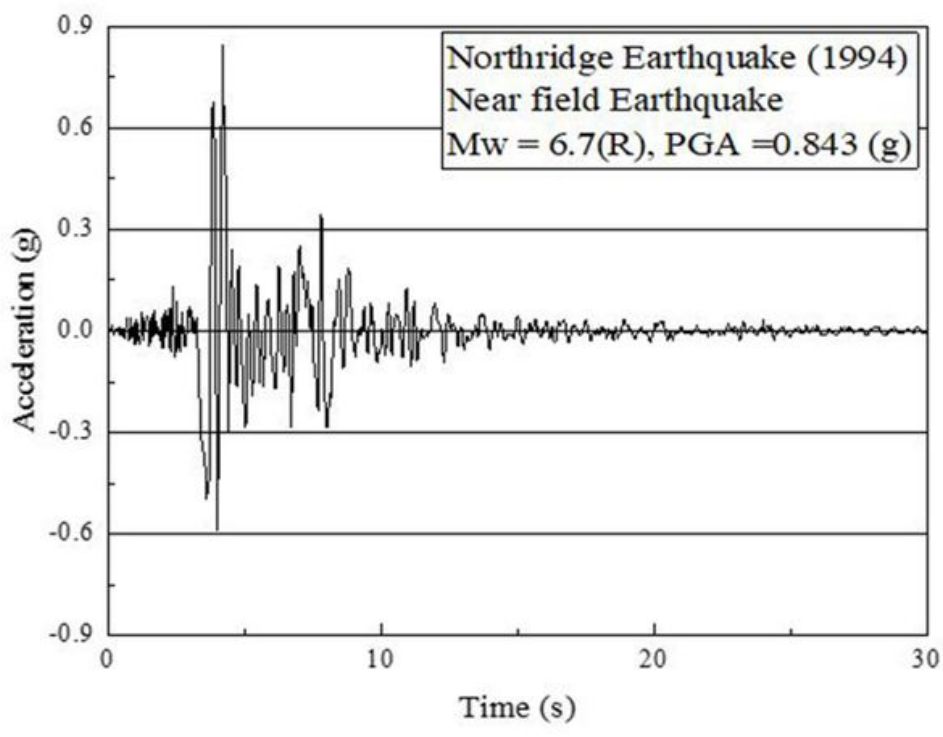

(d)

\section{Figure 2}

Seismic records adopted in this study: (a) El Centro earthquake (b) Hachinohe earthquake (c) Kobe earthquake (d) Northridge earthquake 


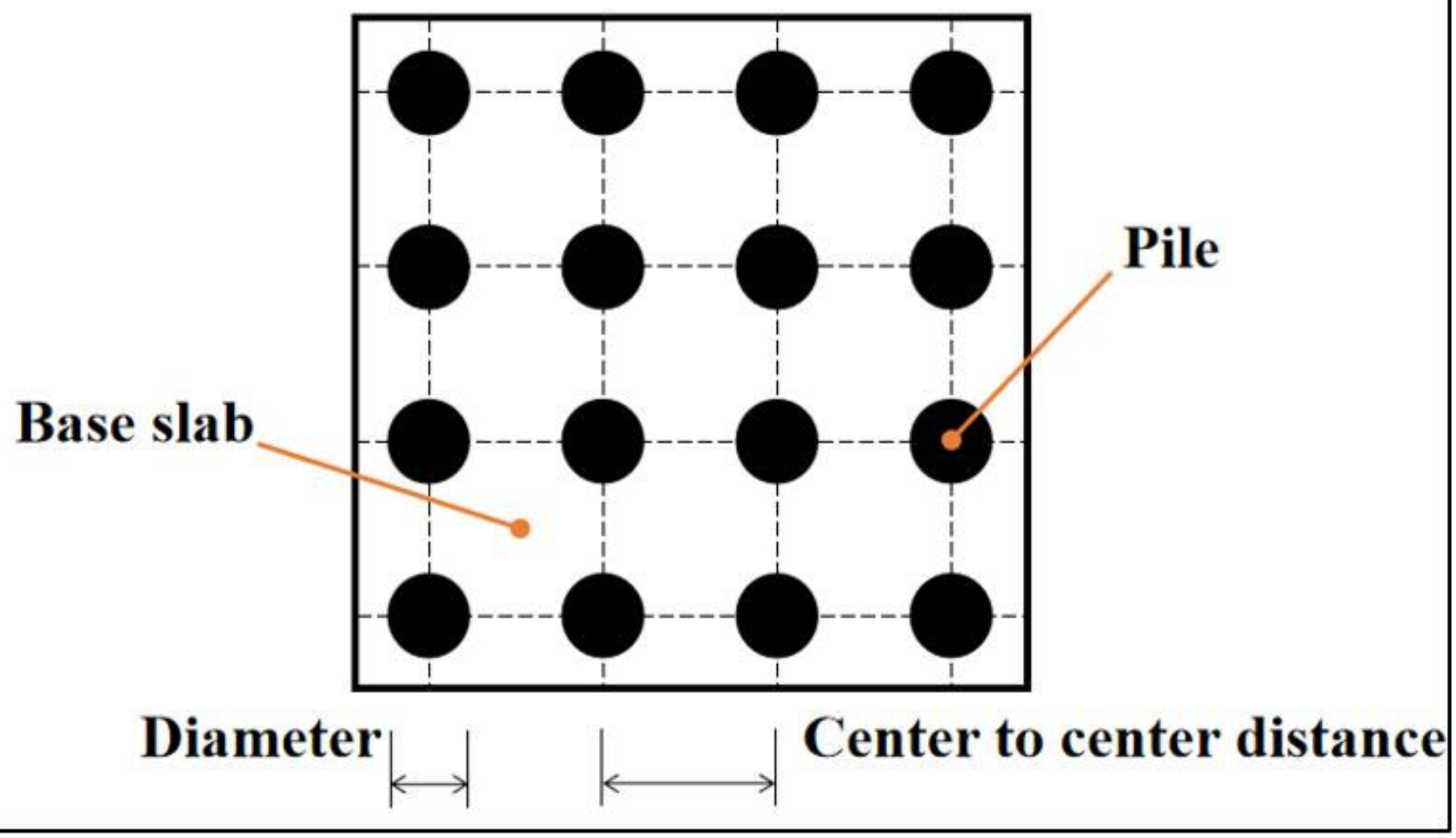

Figure 3

The pile arrangement used in this study

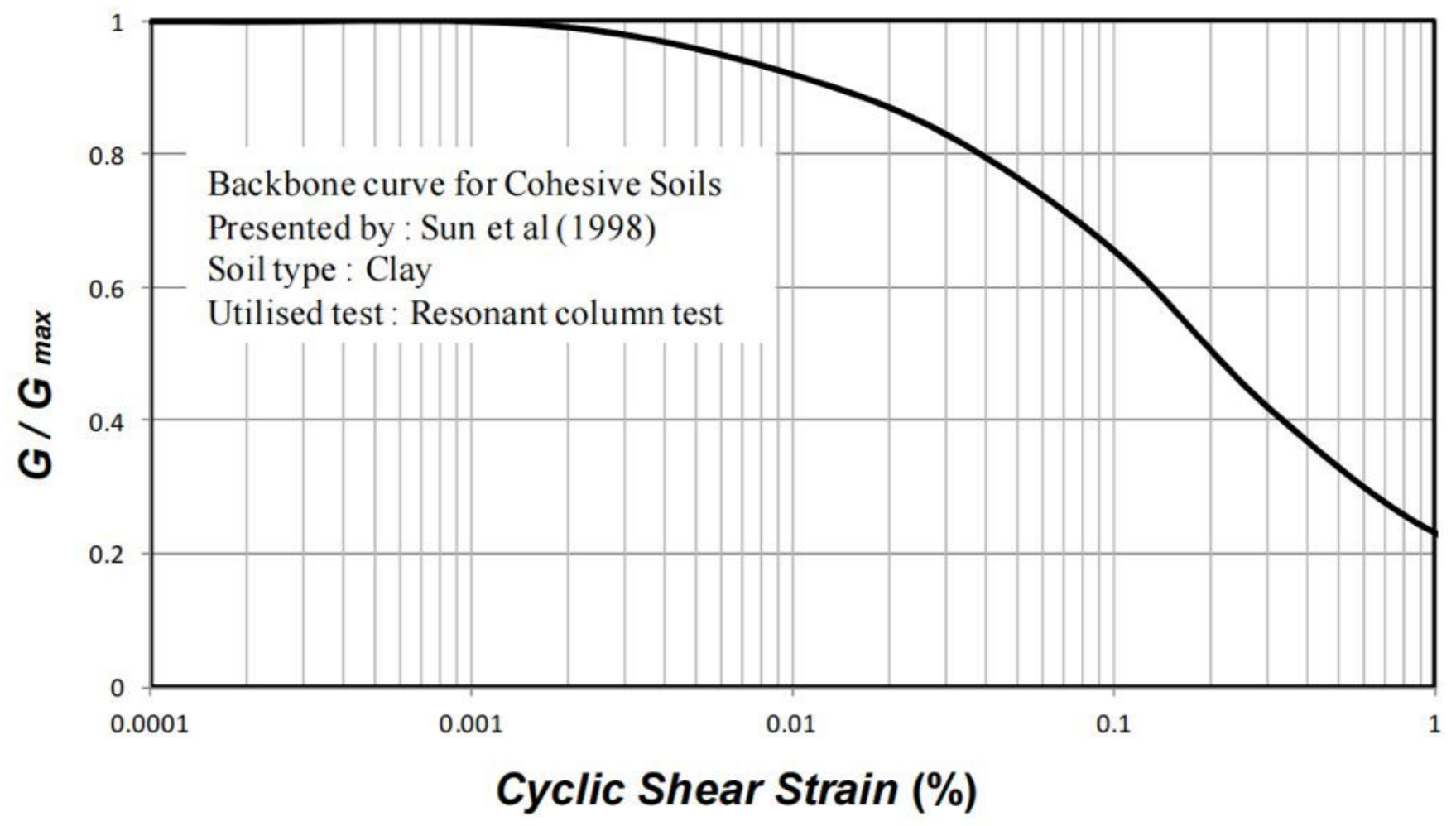


Figure 4

Shear modulus reduction curve of cohesive soils (after Sun et al. 1998)

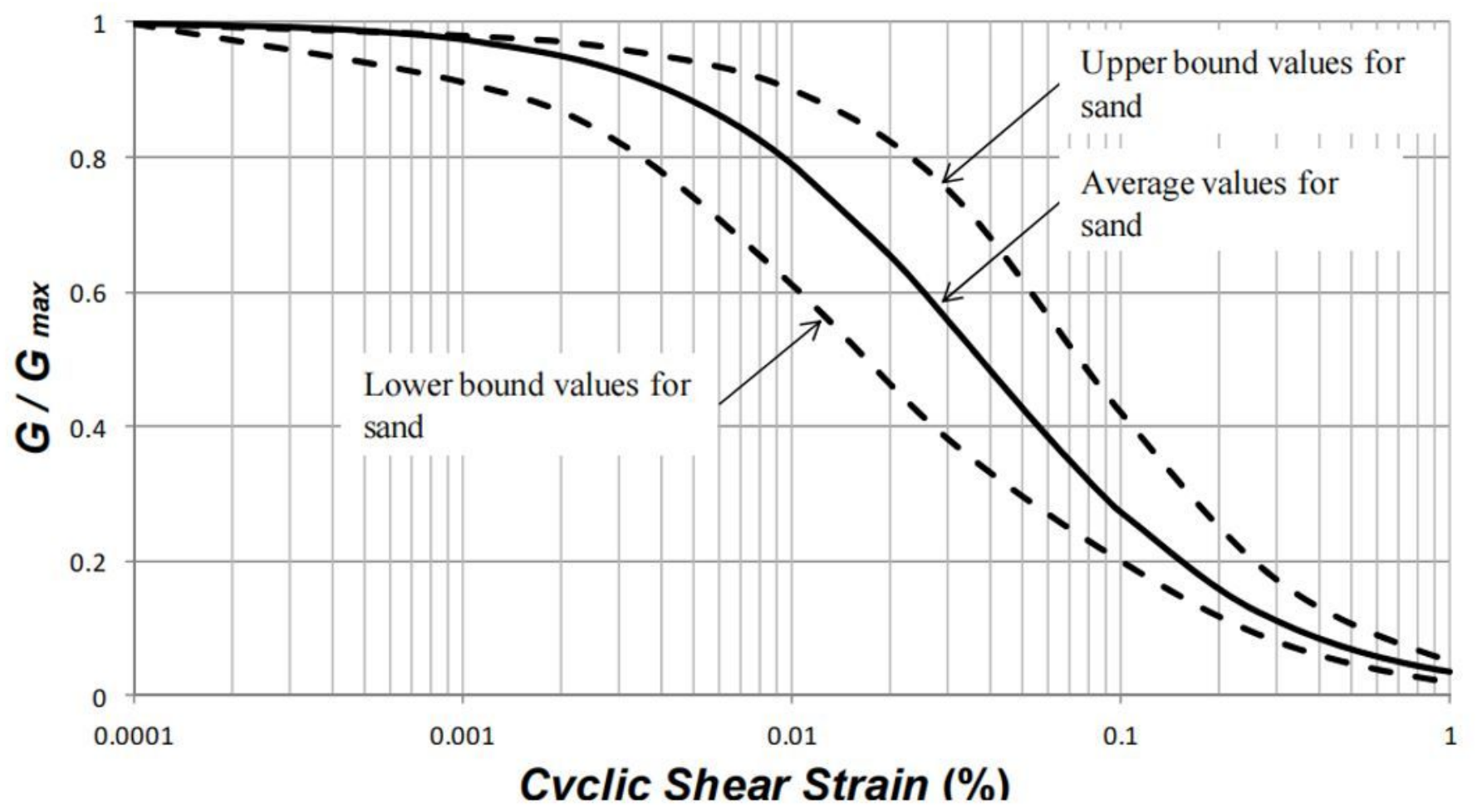

Figure 5

Shear modulus reduction curve of cohesionless soils (after Seed et al. 1986) 


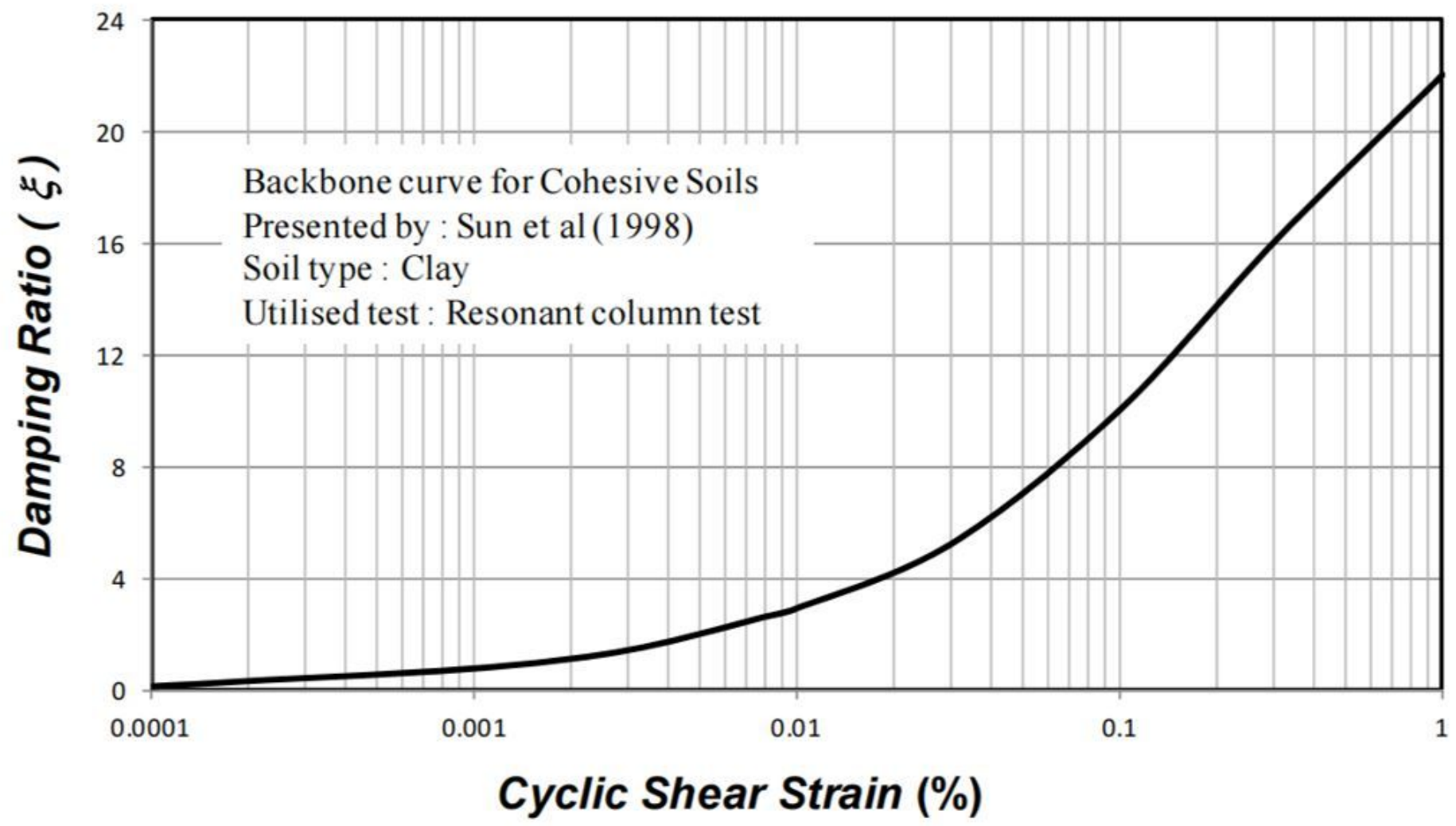

Figure 6

Damping curve of cohesive soils (after Sun et al. 1998) 


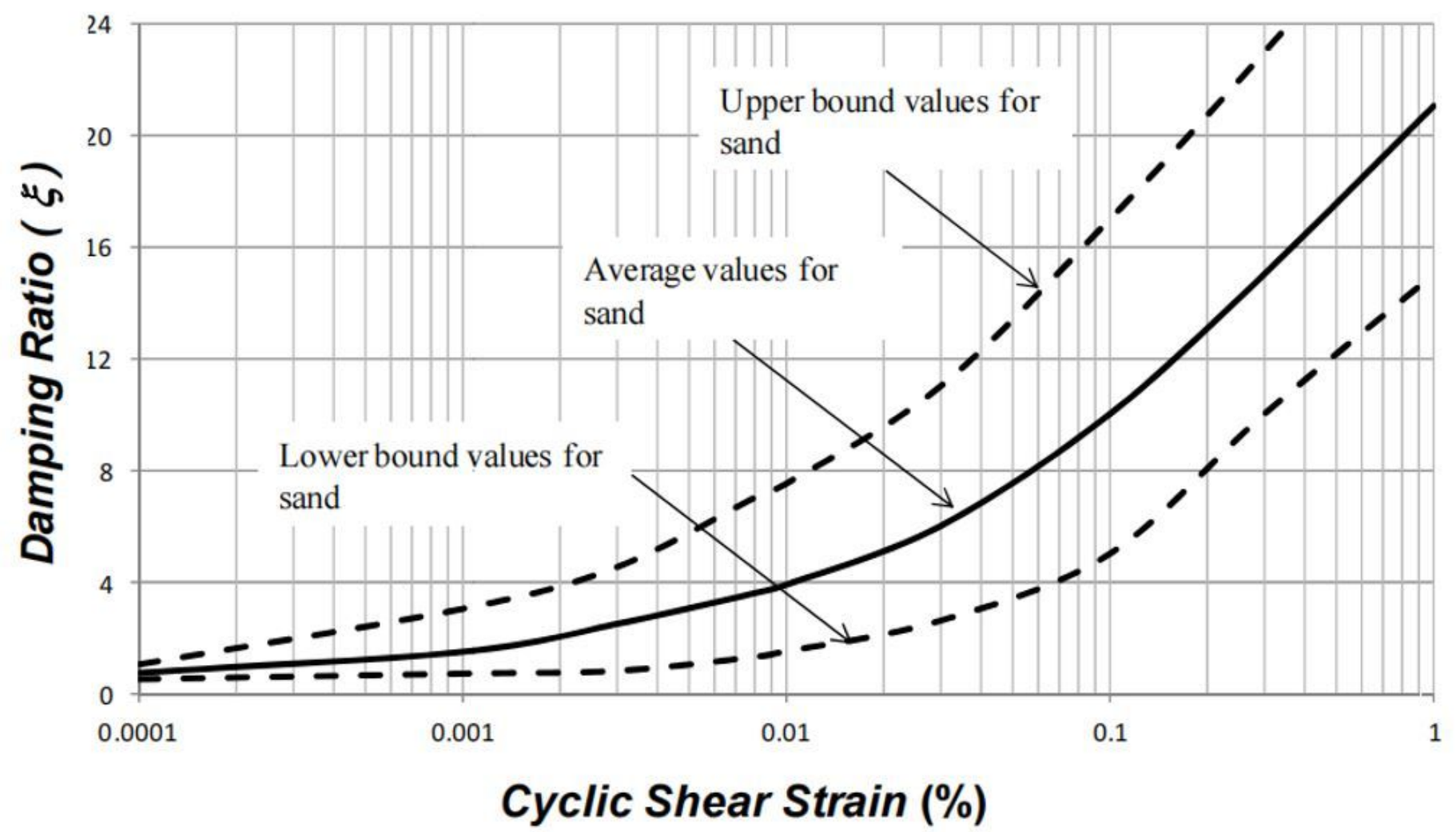

Figure 7

Damping curve of cohesionless soils (after Seed et al. 1986) 


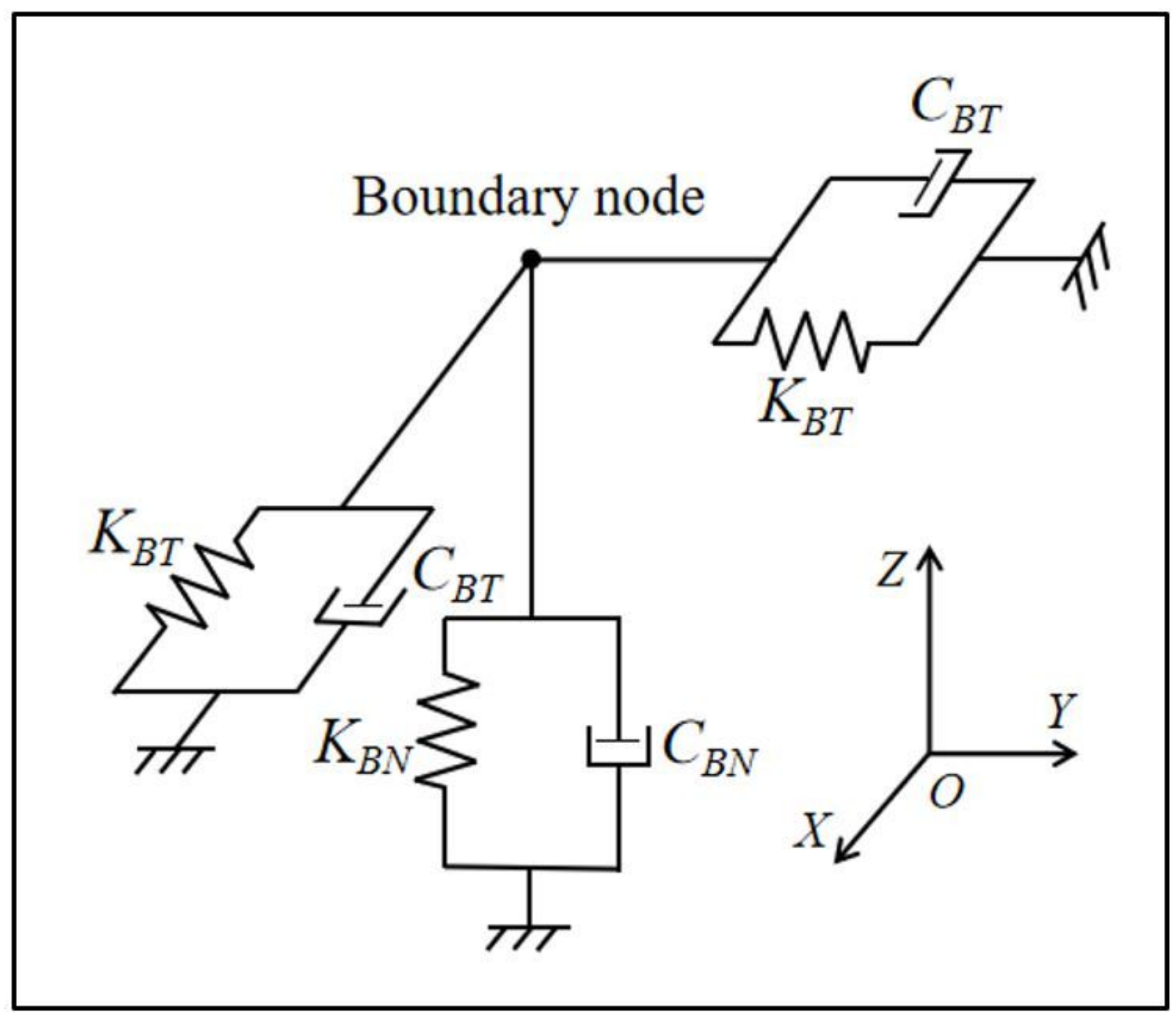

Figure 8

Viscous-spring boundary 


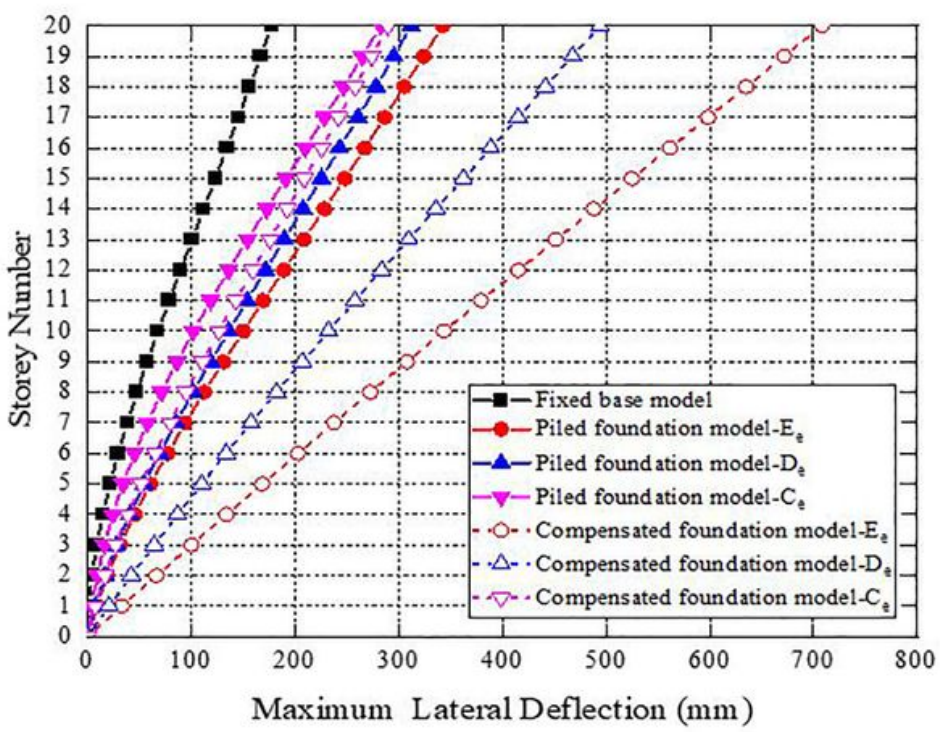

(a)

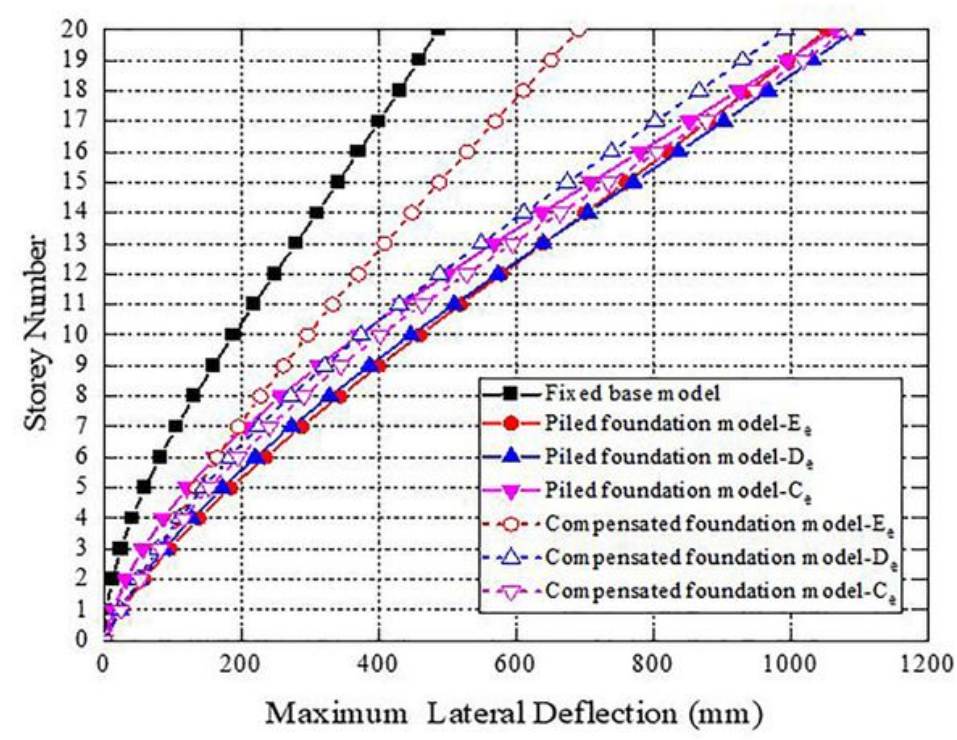

(c)

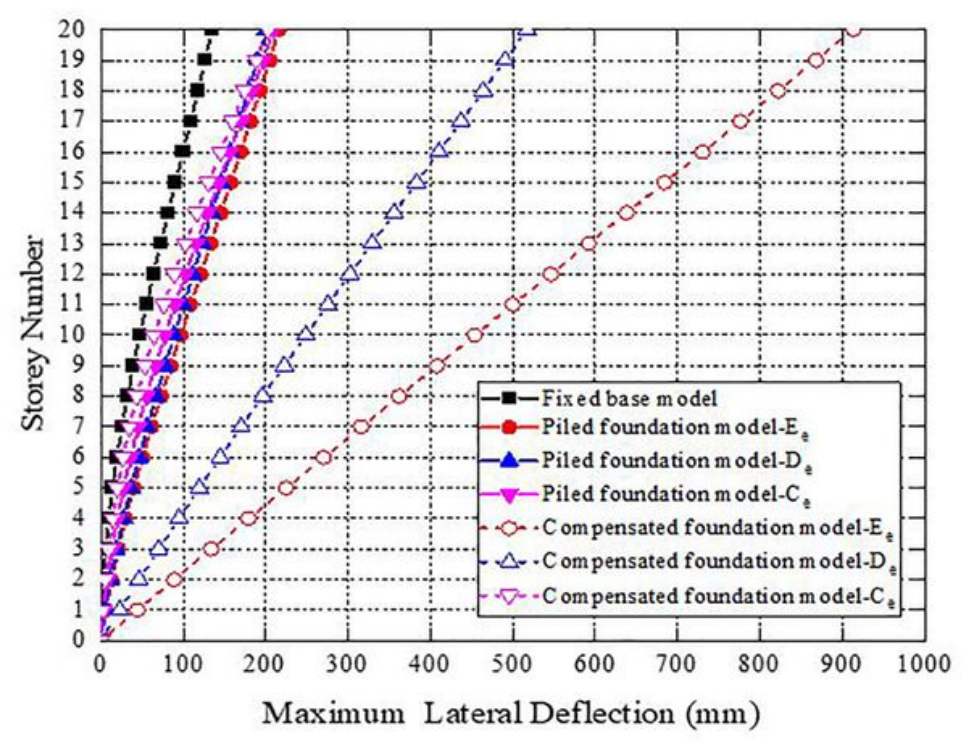

(b)

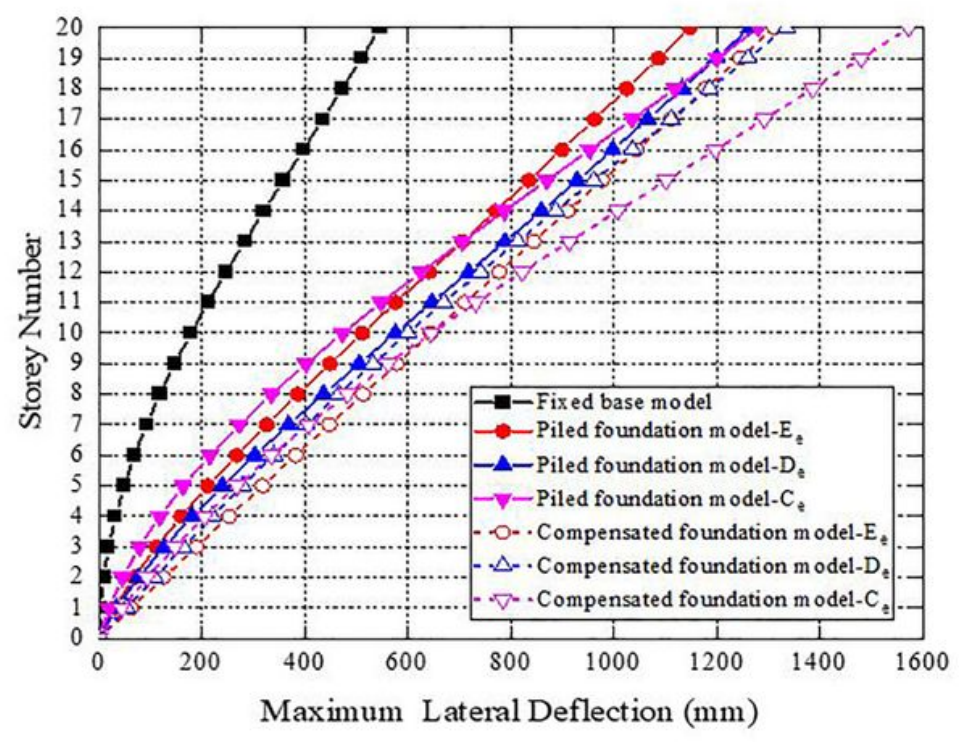

(d)

\section{Figure 9}

Maximum lateral deflections of 20-storey structure (height-width ratio=6) with various foundation types and subsoil types under different seismic records: (a) El Centro earthquake (b) Hachinohe earthquake (c) Kobe earthquake (d) Northridge earthquake 


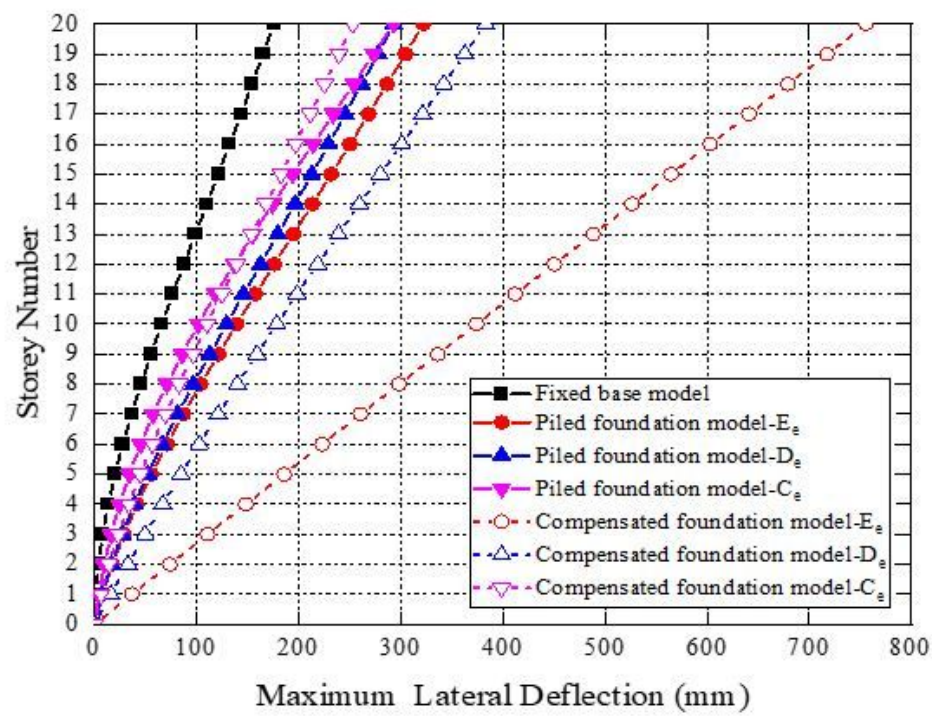

(a)

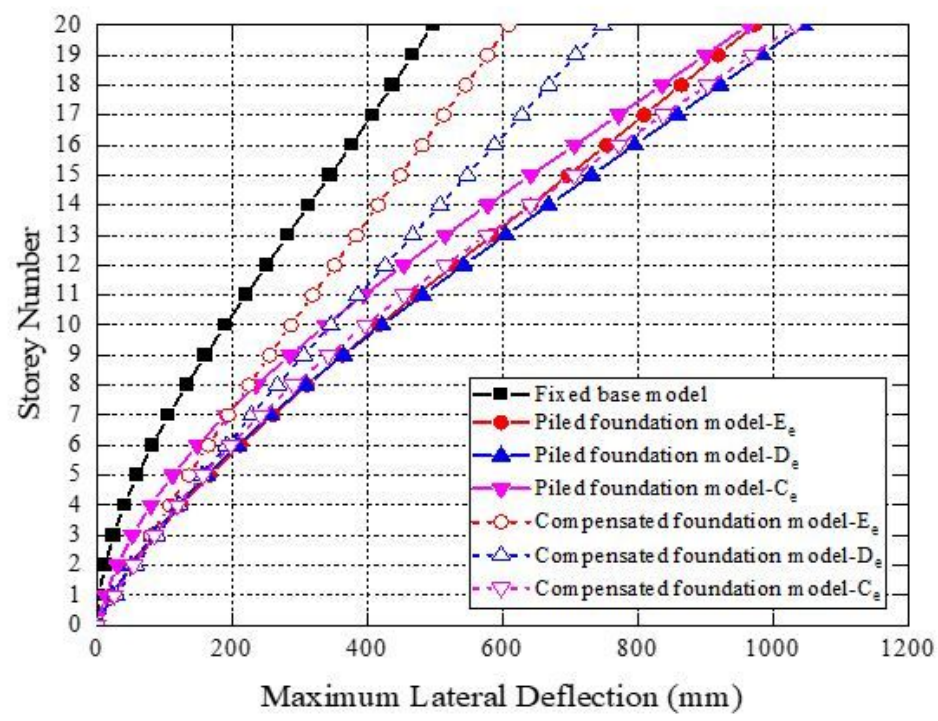

(c)

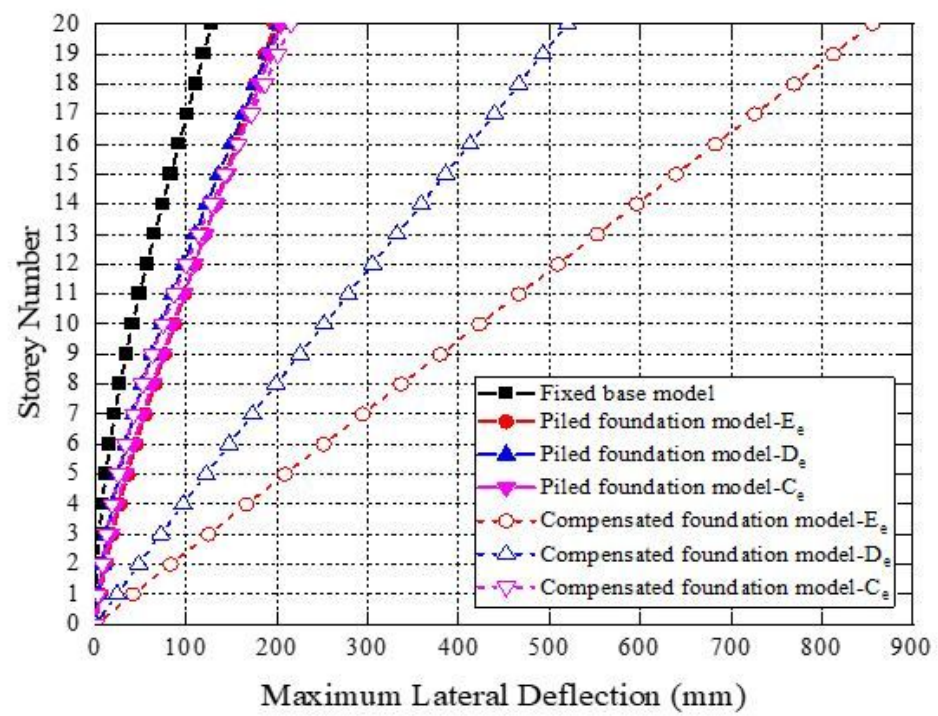

(b)

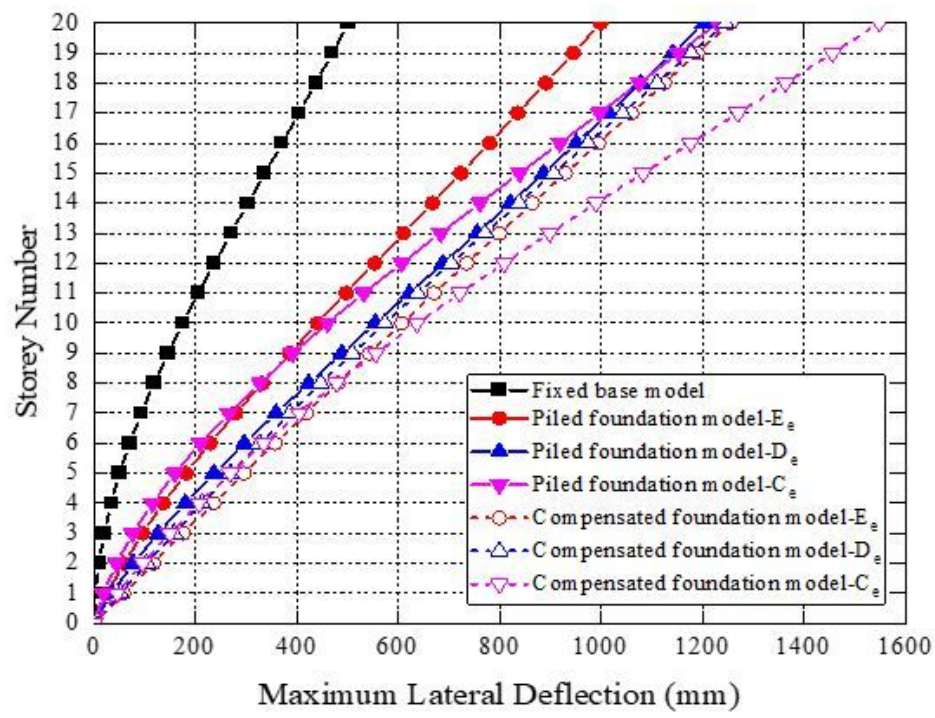

(d)

\section{Figure 10}

Maximum lateral deflections of 20-storey structure (height-width ratio=5) with various foundation types and subsoil types under different seismic records: (a) El Centro earthquake (b) Hachinohe earthquake (c) Kobe earthquake (d) Northridge earthquake 


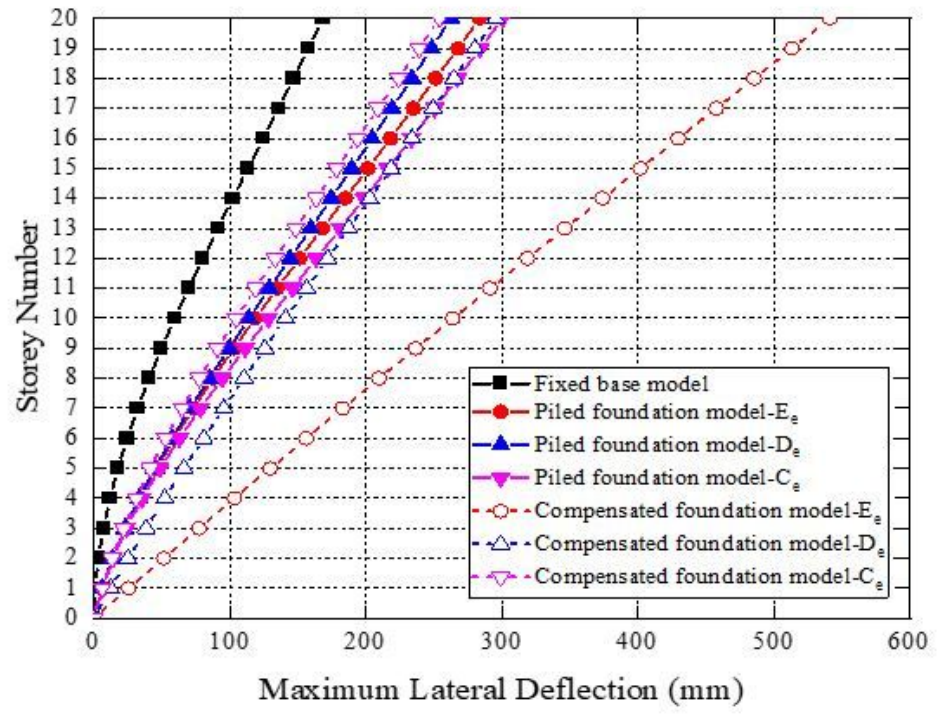

(a)

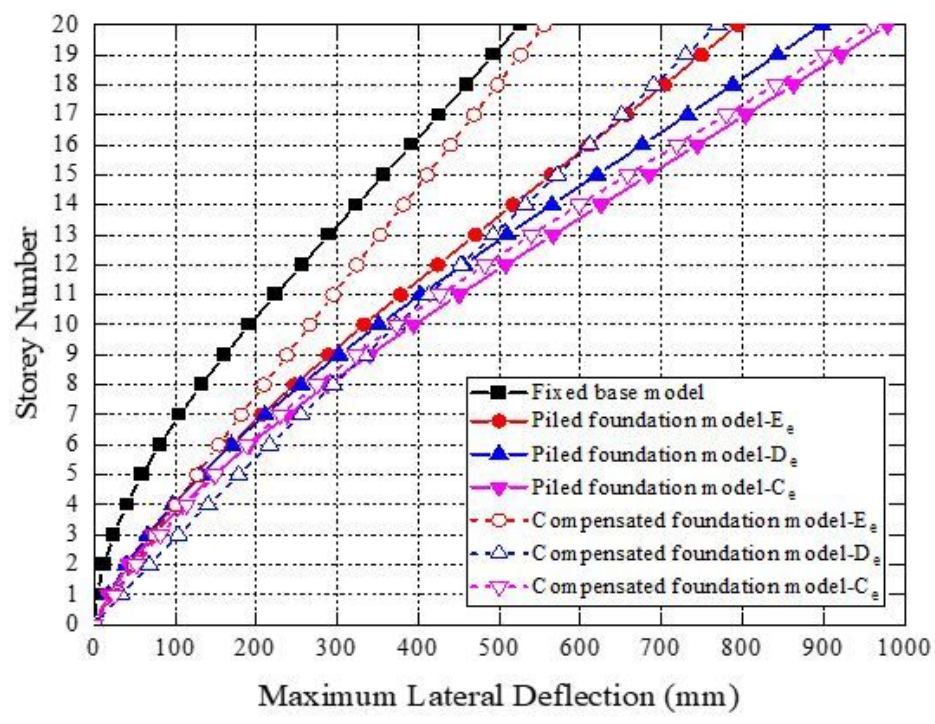

(c)

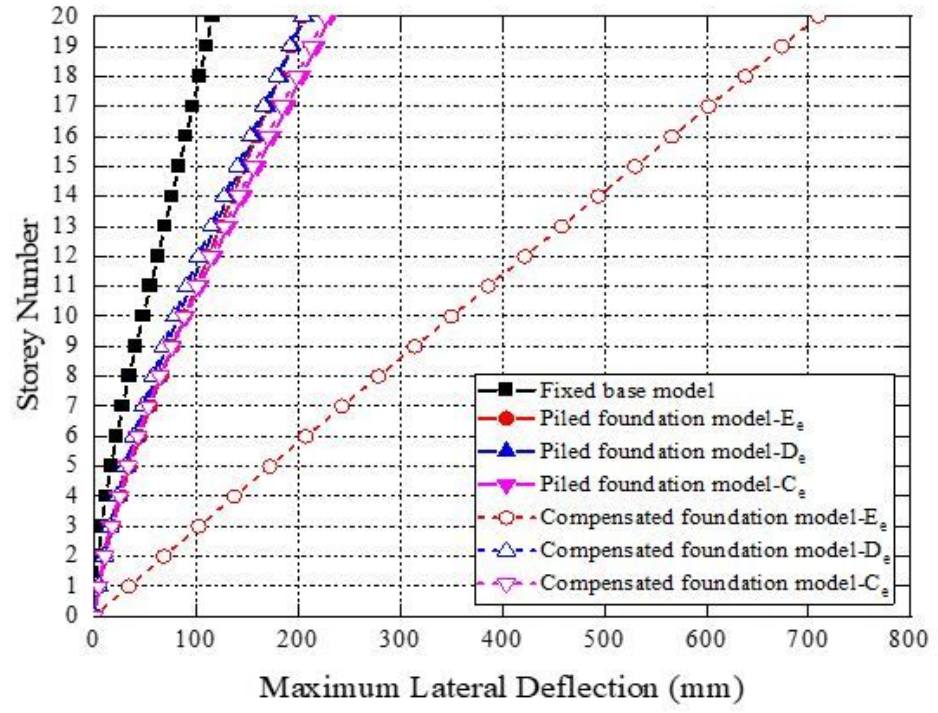

(b)

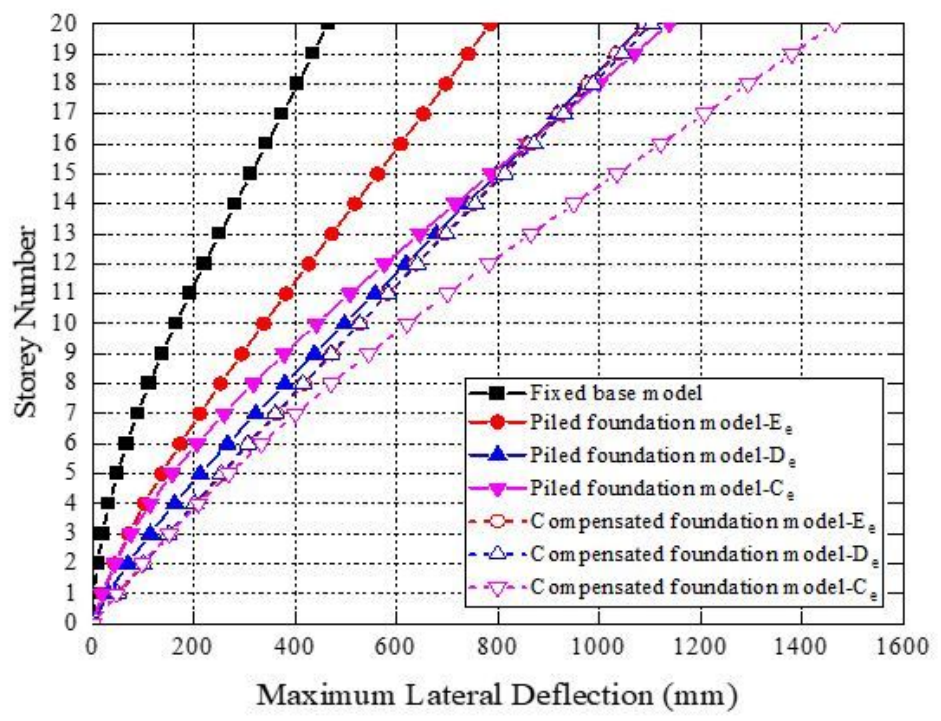

(d)

\section{Figure 11}

Maximum lateral deflections of 20-storey structure (height-width ratio=4) with various foundation types and subsoil types under different seismic records: (a) El Centro earthquake (b) Hachinohe earthquake (c) Kobe earthquake (d) Northridge earthquake 


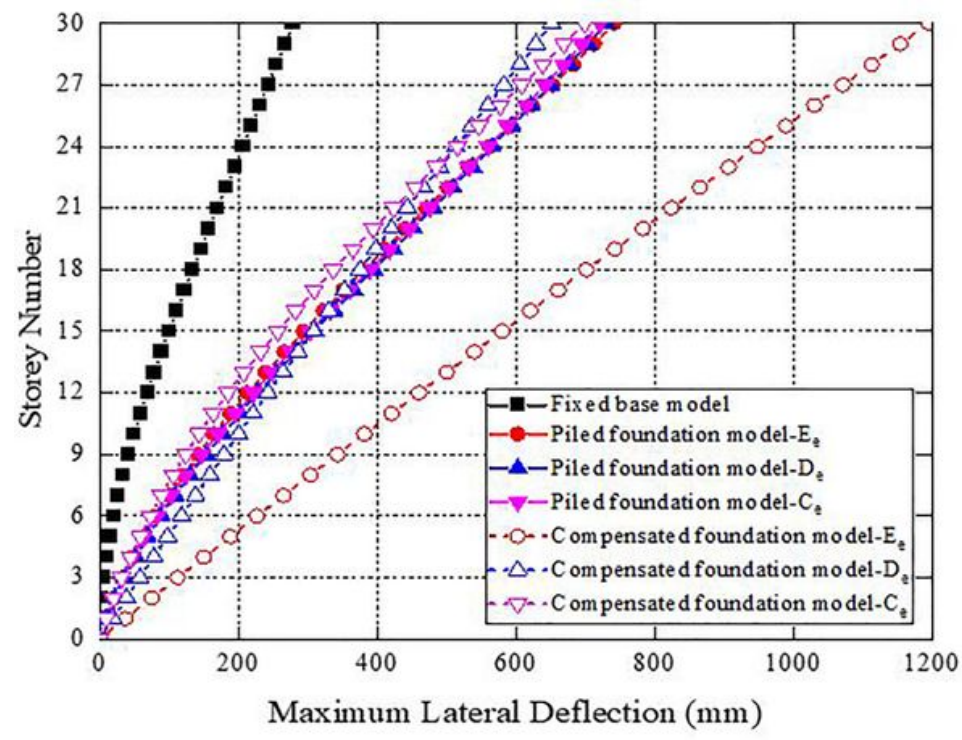

(a)

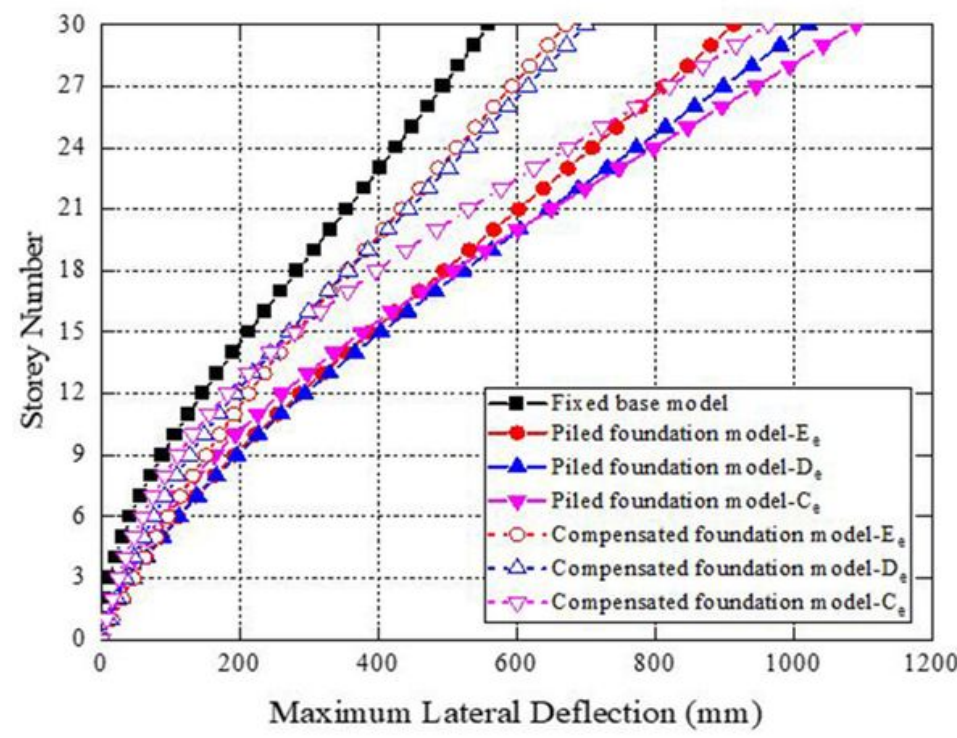

(c)

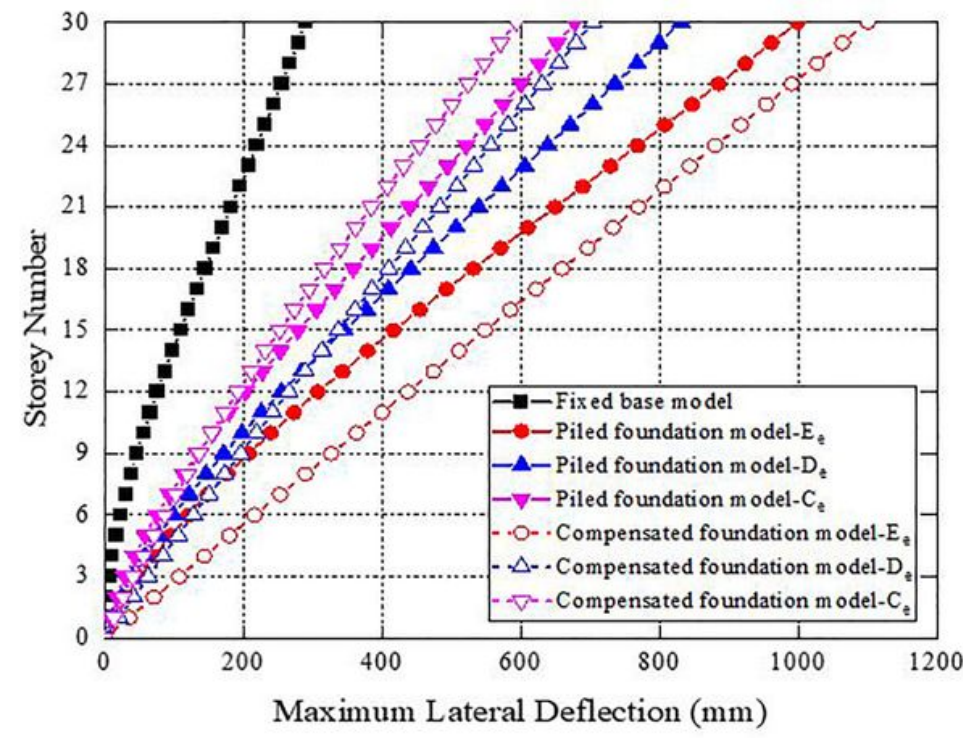

(b)

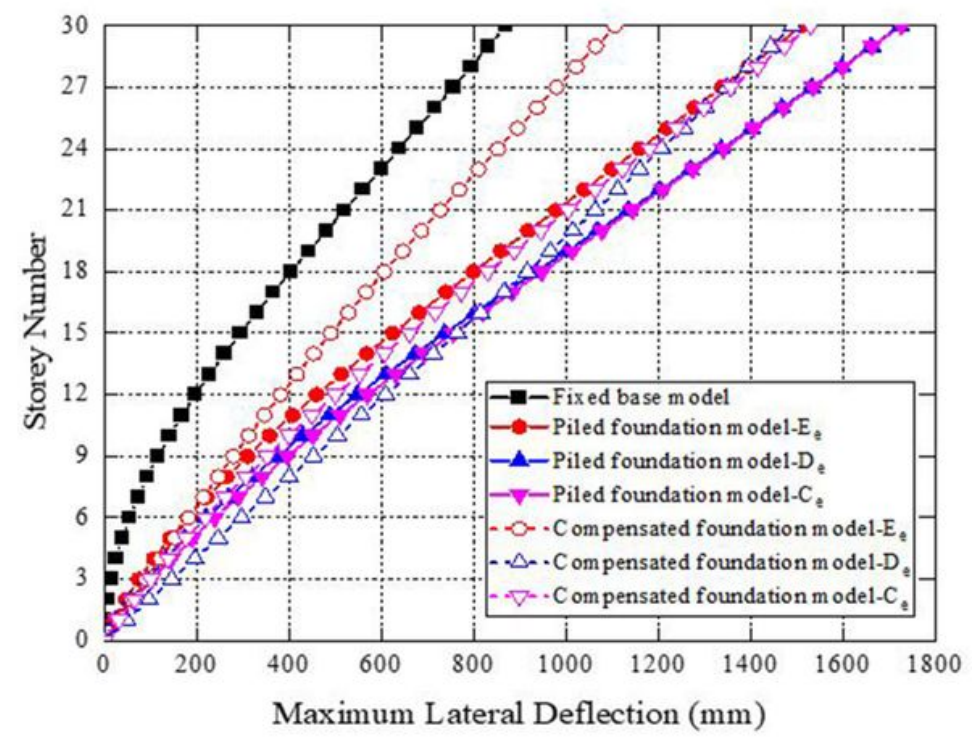

(d)

\section{Figure 12}

Maximum lateral deflections of 30-storey structure (height-width ratio=6) with various foundation types and subsoil types under different seismic records: (a) El Centro earthquake (b) Hachinohe earthquake (c) Kobe earthquake (d) Northridge earthquake 


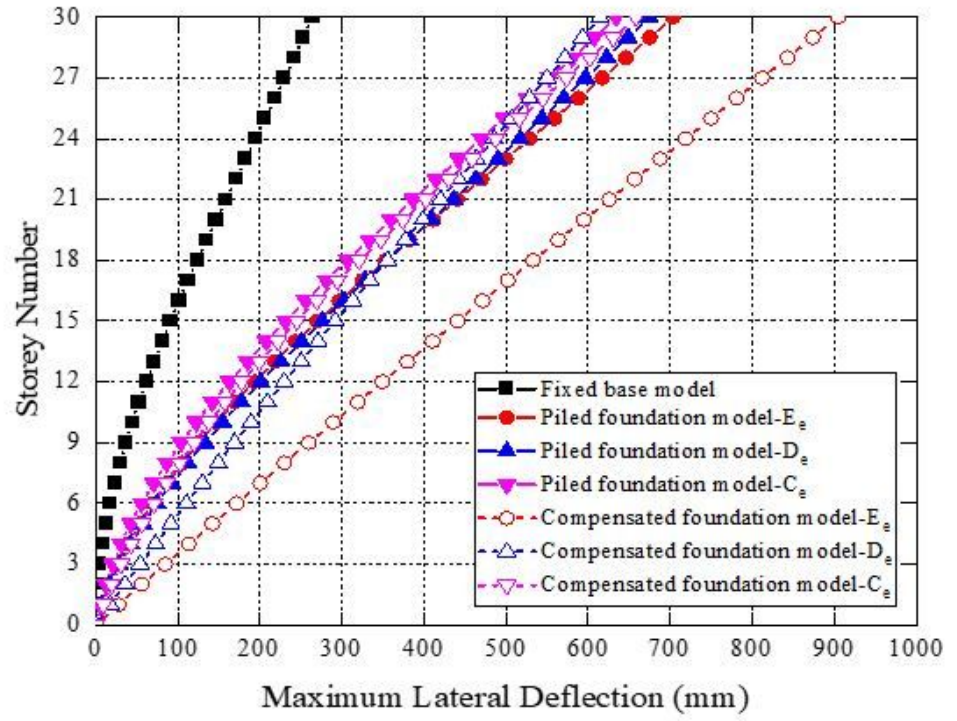

(a)

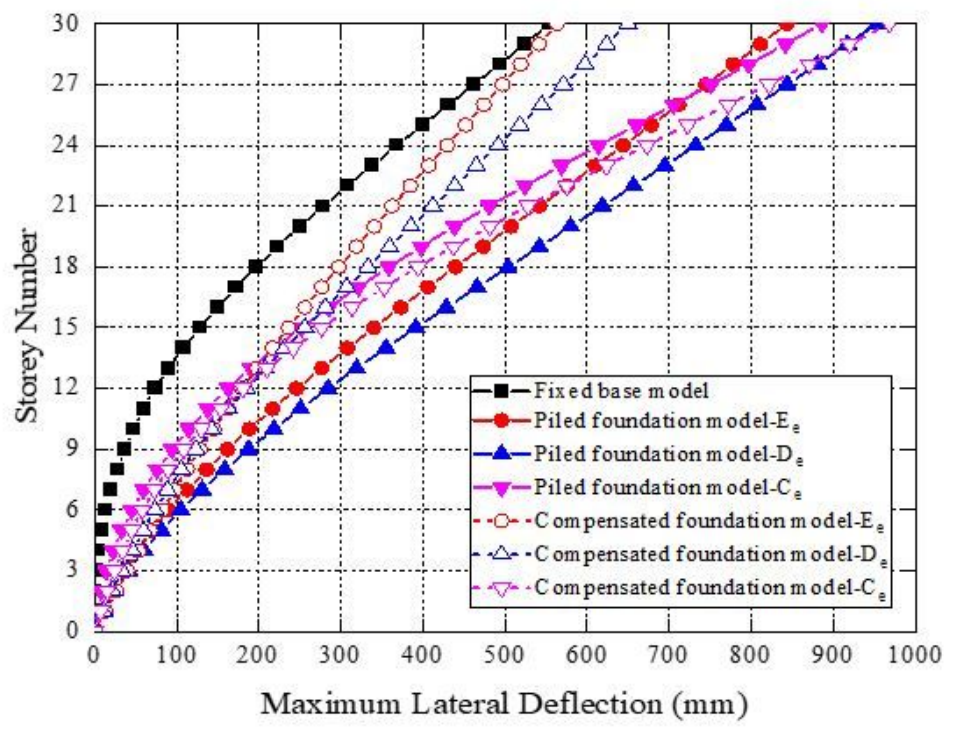

(c)

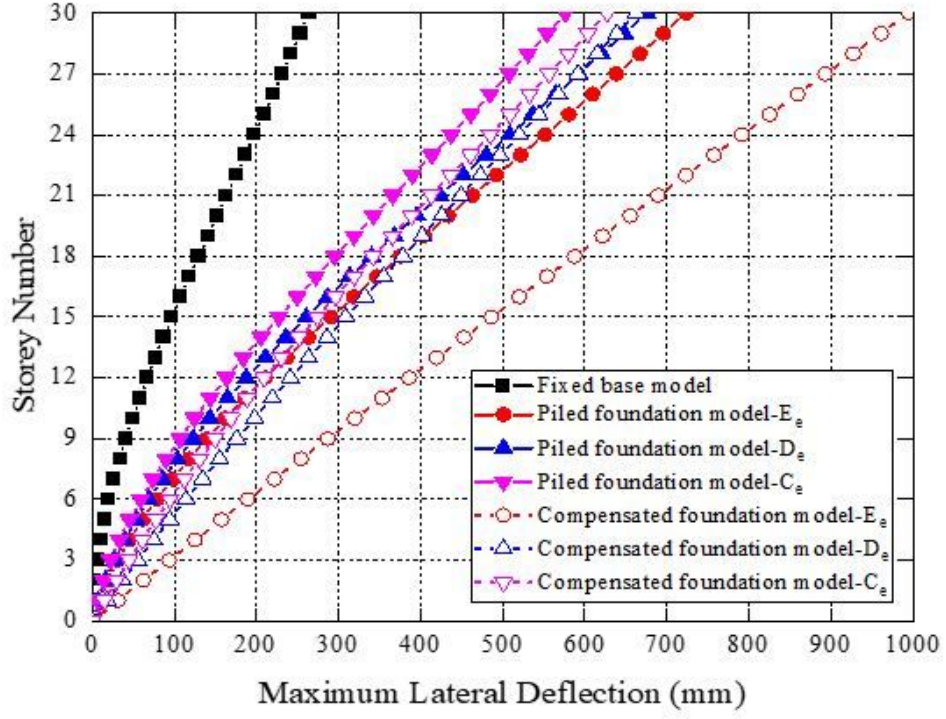

(b)

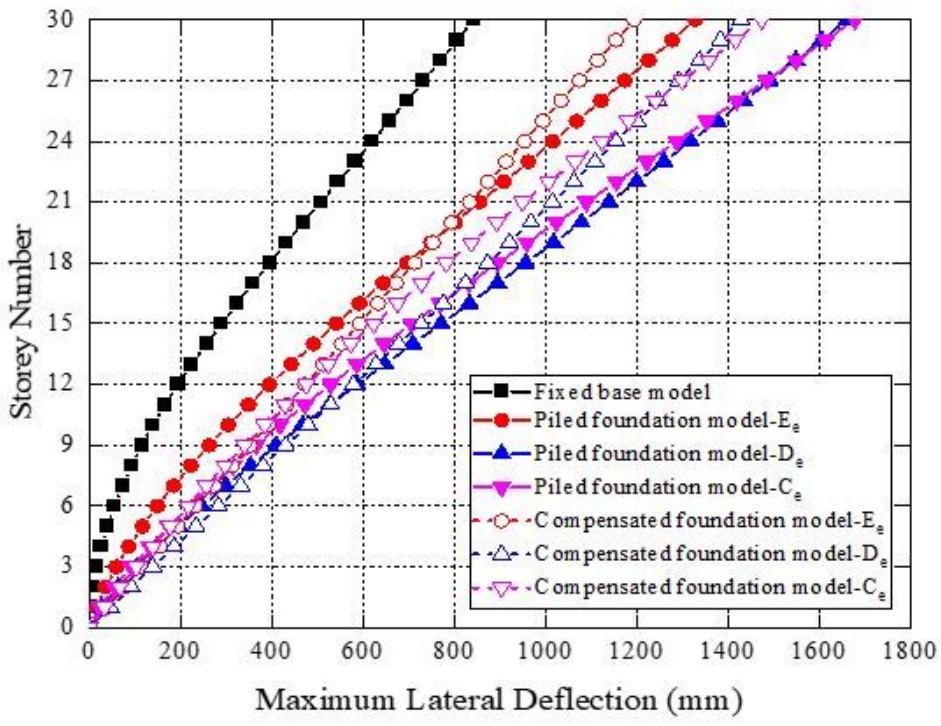

(d)

\section{Figure 13}

Maximum lateral deflections of 30-storey structure (height-width ratio=5) with various foundation types and subsoil types under different seismic records: (a) El Centro earthquake (b) Hachinohe earthquake (c) Kobe earthquake (d) Northridge earthquake 


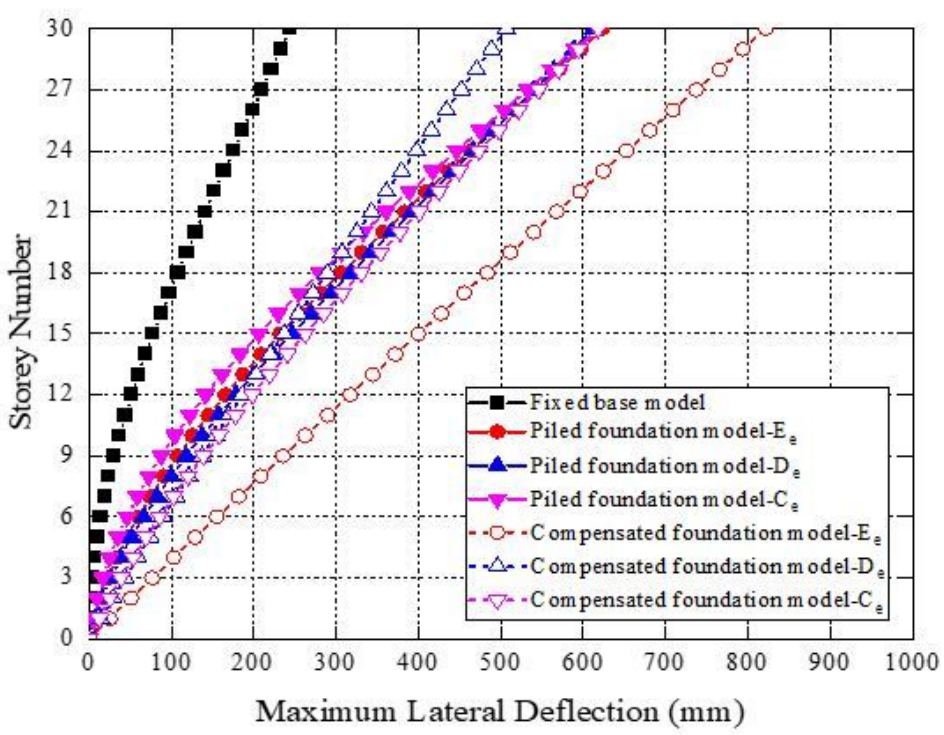

(a)

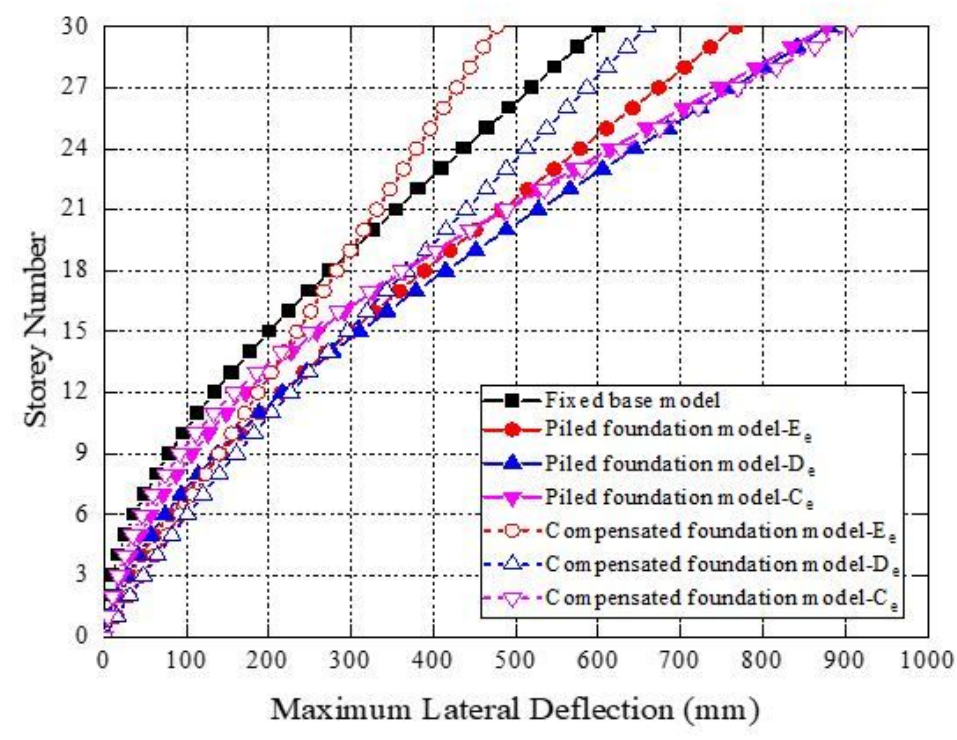

(c)

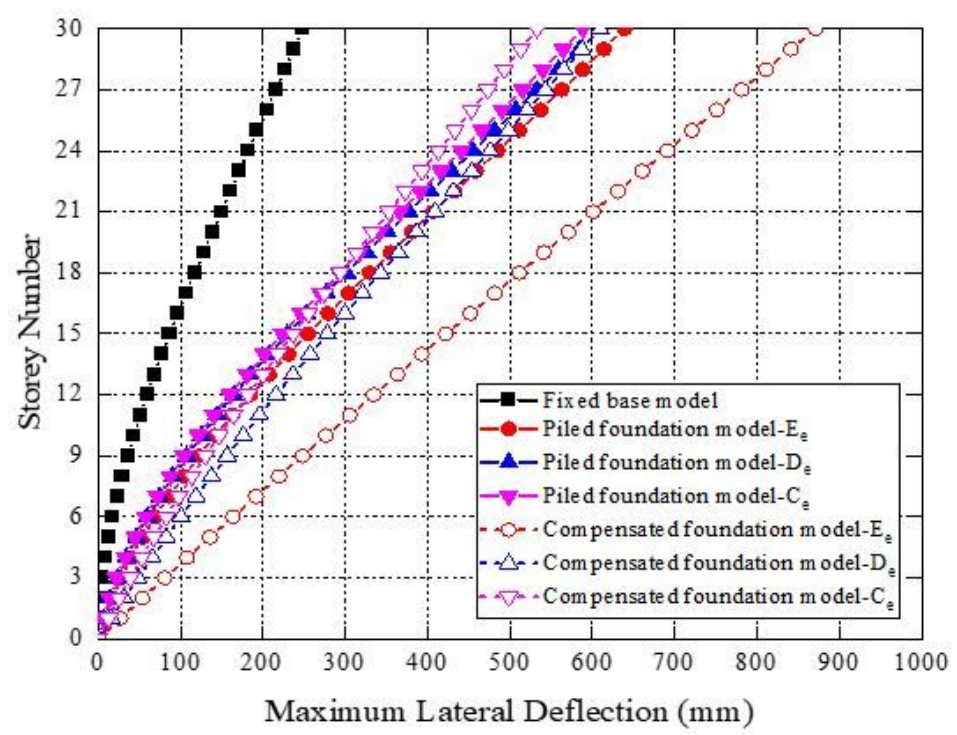

(b)

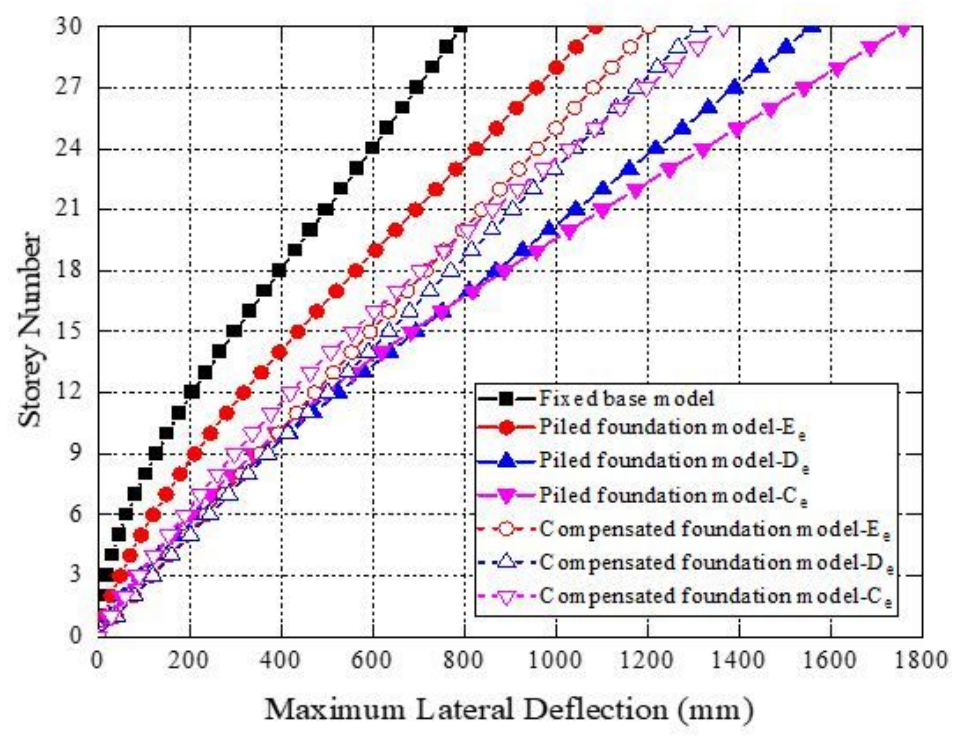

(d)

Figure 14

Maximum lateral deflections of 30-storey structure (height-width ratio=4) with various foundation types and subsoil types under different seismic records: (a) El Centro earthquake (b) Hachinohe earthquake (c) Kobe earthquake (d) Northridge earthquake 


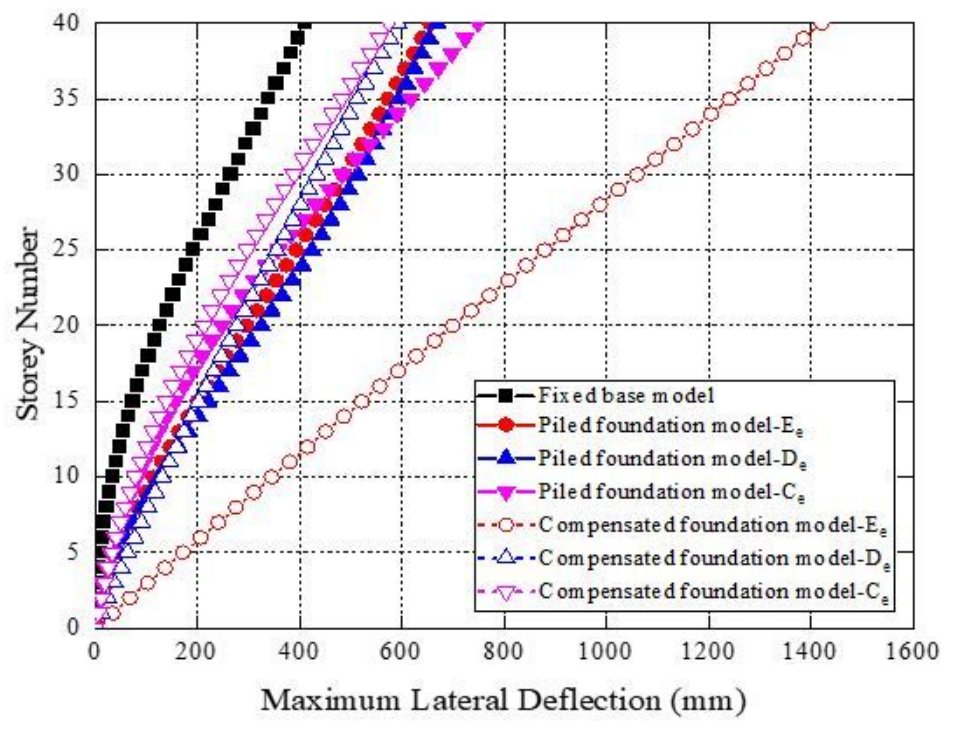

(a)

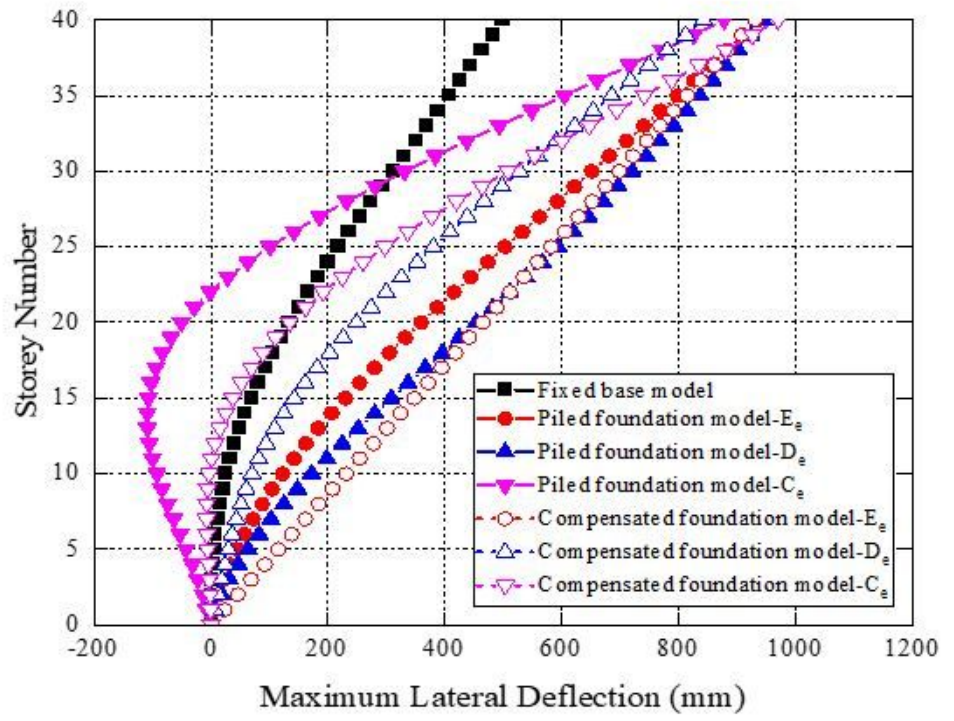

(c)

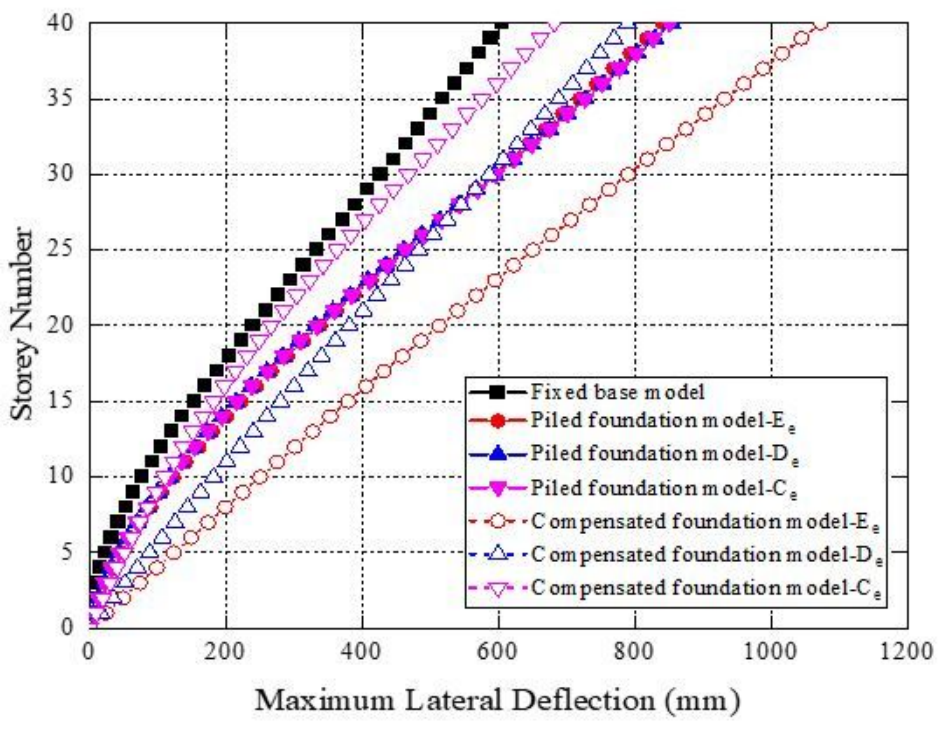

(b)

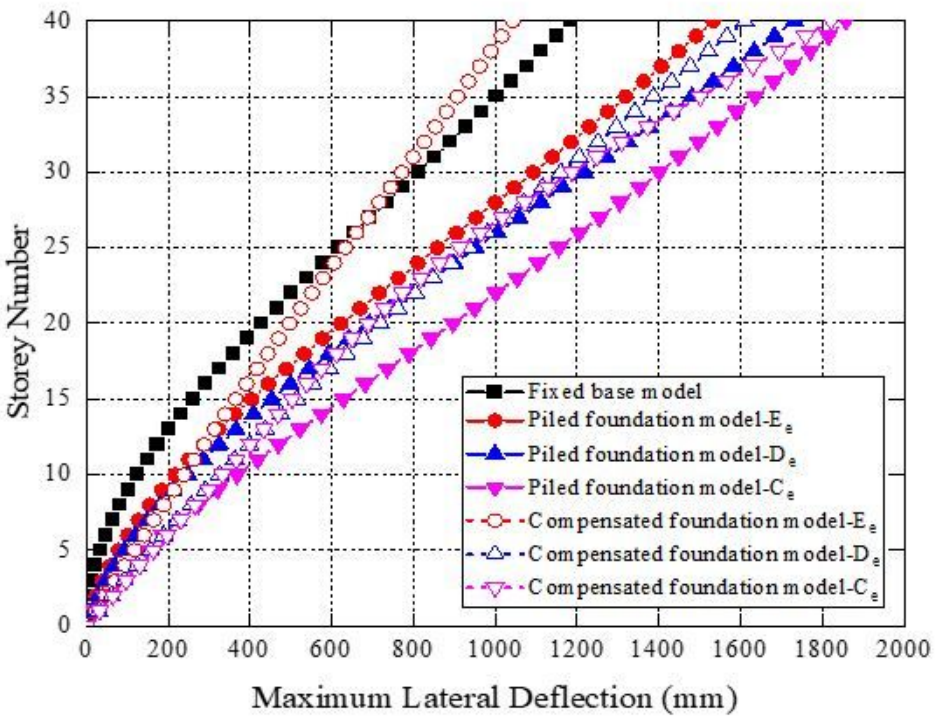

(d)

\section{Figure 15}

Maximum lateral deflections of 40-storey structure (height-width ratio=6) with various foundation types and subsoil types under different seismic records: (a) El Centro earthquake (b) Hachinohe earthquake (c) Kobe earthquake (d) Northridge earthquake 


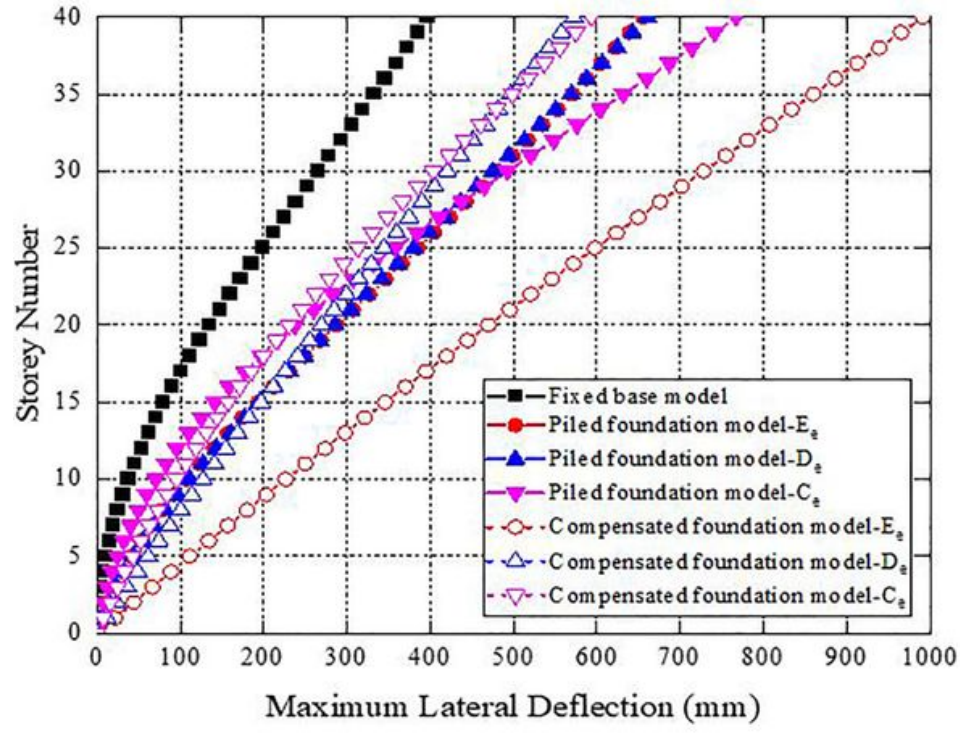

(a)

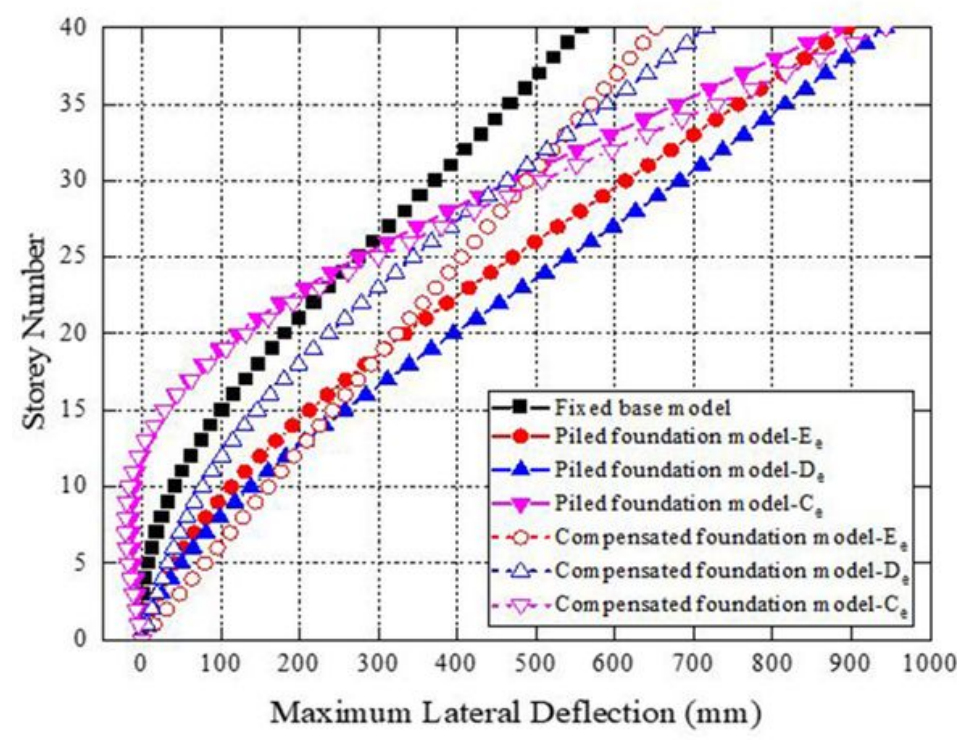

(c)

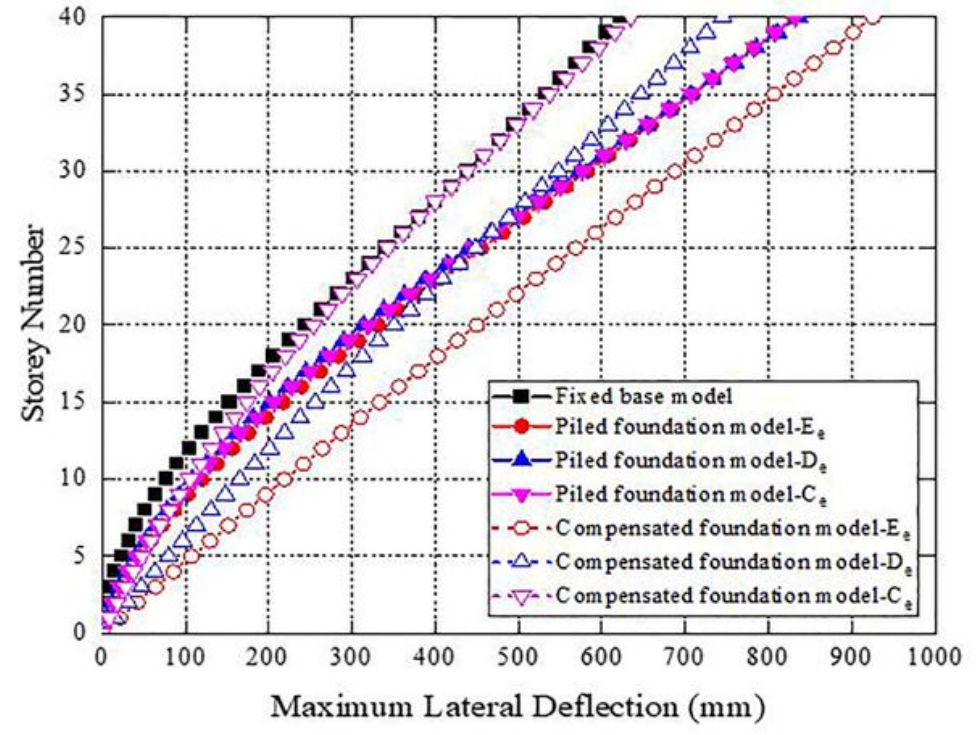

(b)

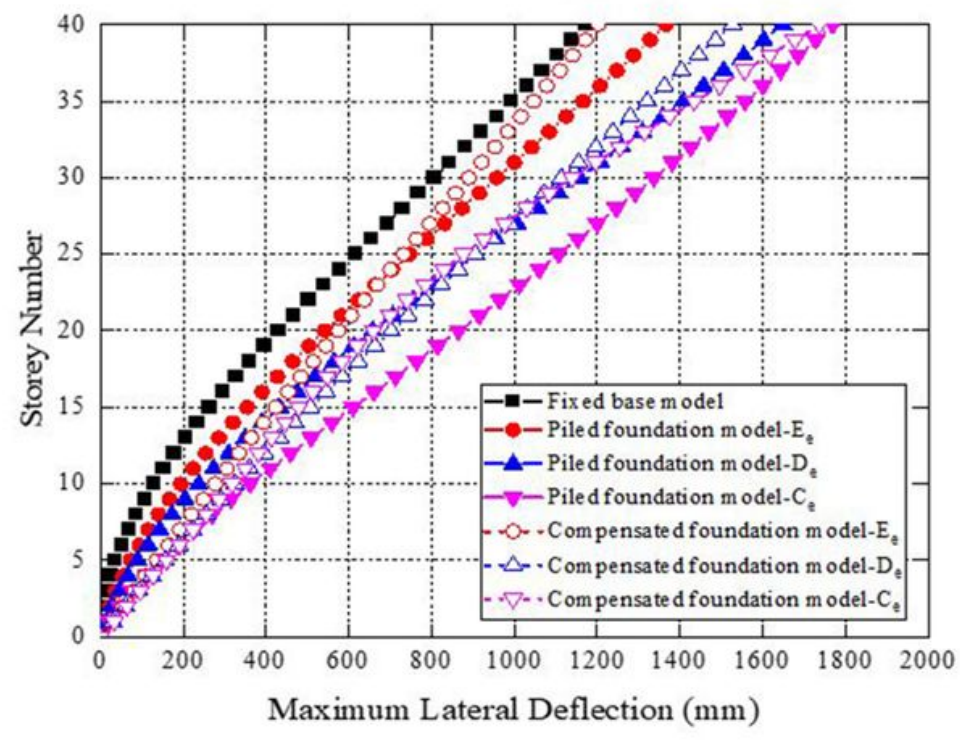

(d)

\section{Figure 16}

Maximum lateral deflections of 40-storey structure (height-width ratio=5) with various foundation types and subsoil types under different seismic records: (a) El Centro earthquake (b) Hachinohe earthquake (c) Kobe earthquake (d) Northridge earthquake 


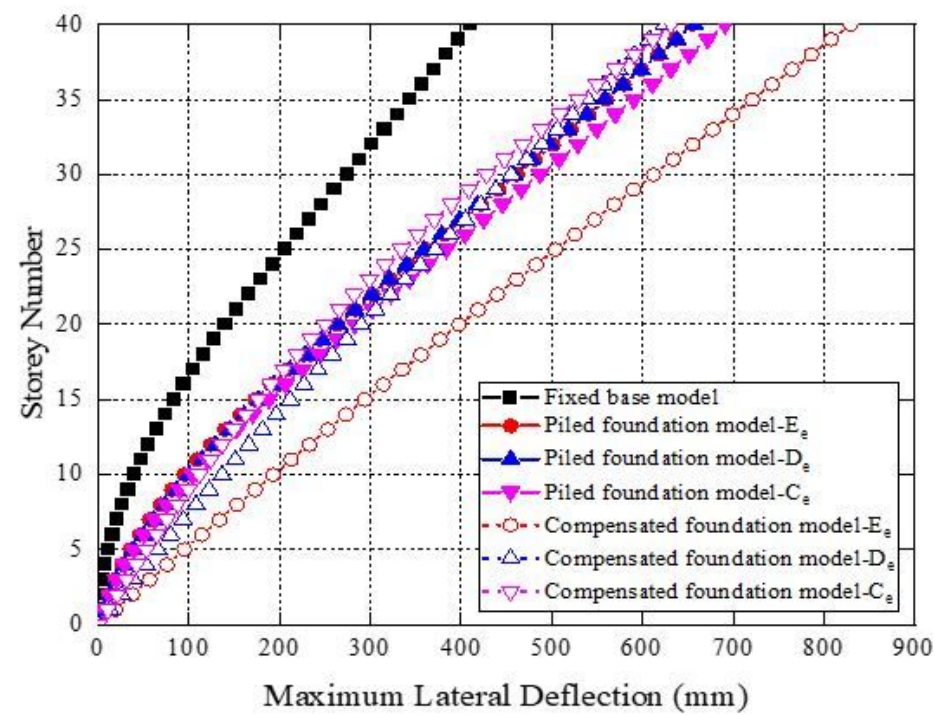

(a)

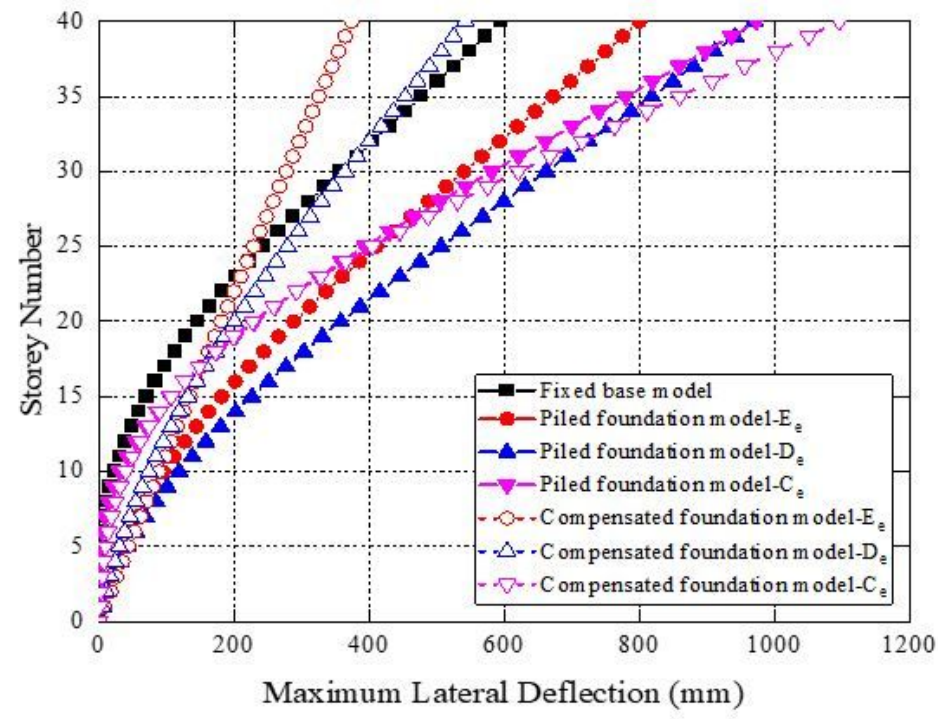

(c)

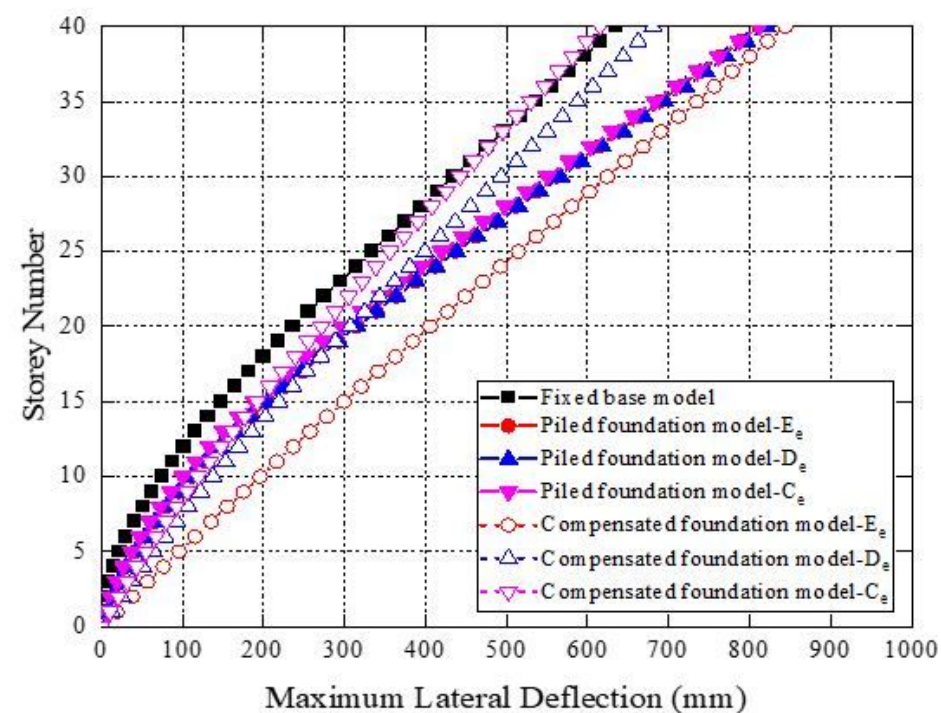

(b)

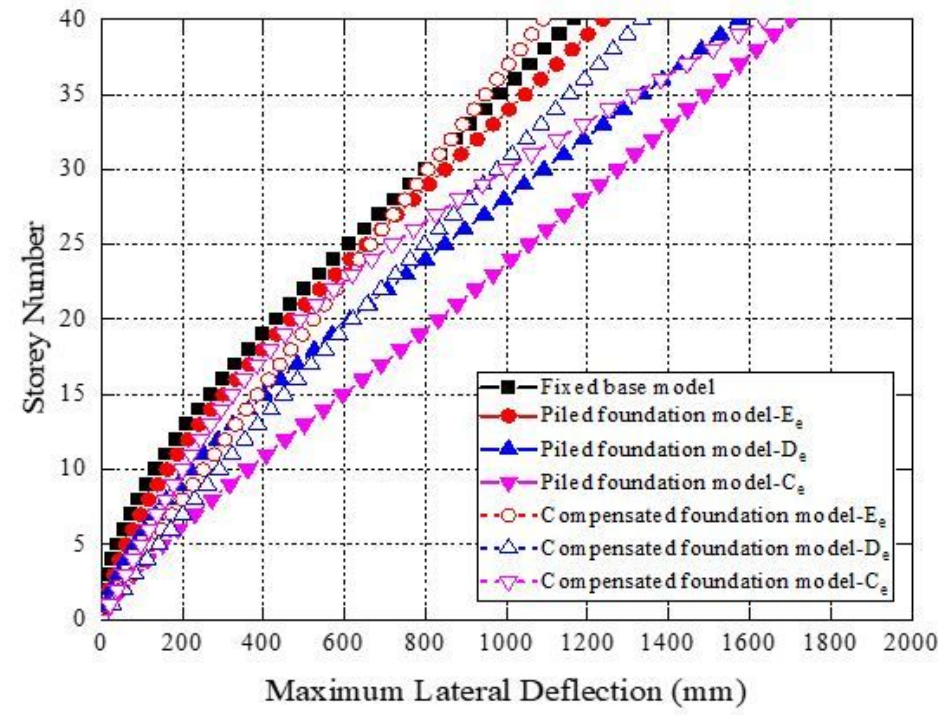

(d)

\section{Figure 17}

Maximum lateral deflections of 40-storey structure (height-width ratio=4) with various foundation types and subsoil types under different seismic records: (a) El Centro earthquake (b) Hachinohe earthquake (c) Kobe earthquake (d) Northridge earthquake 


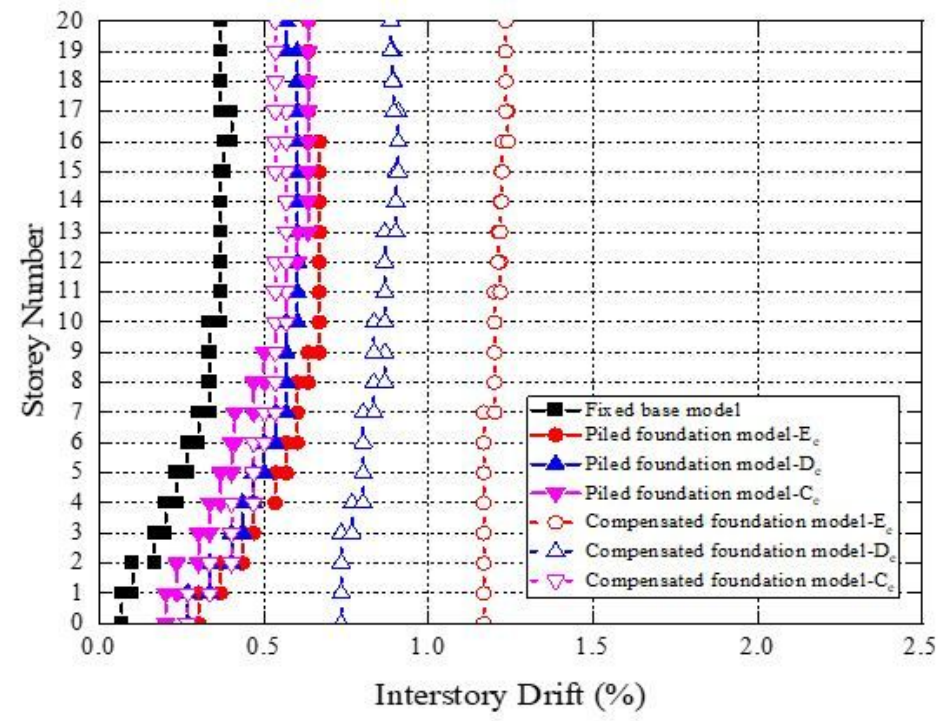

(a)

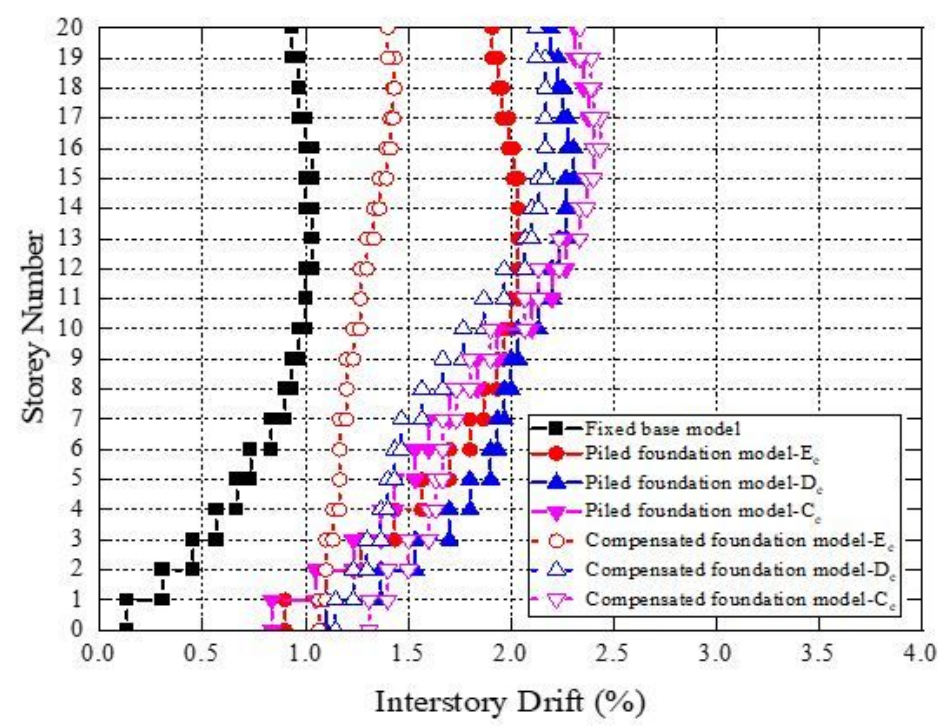

(c)

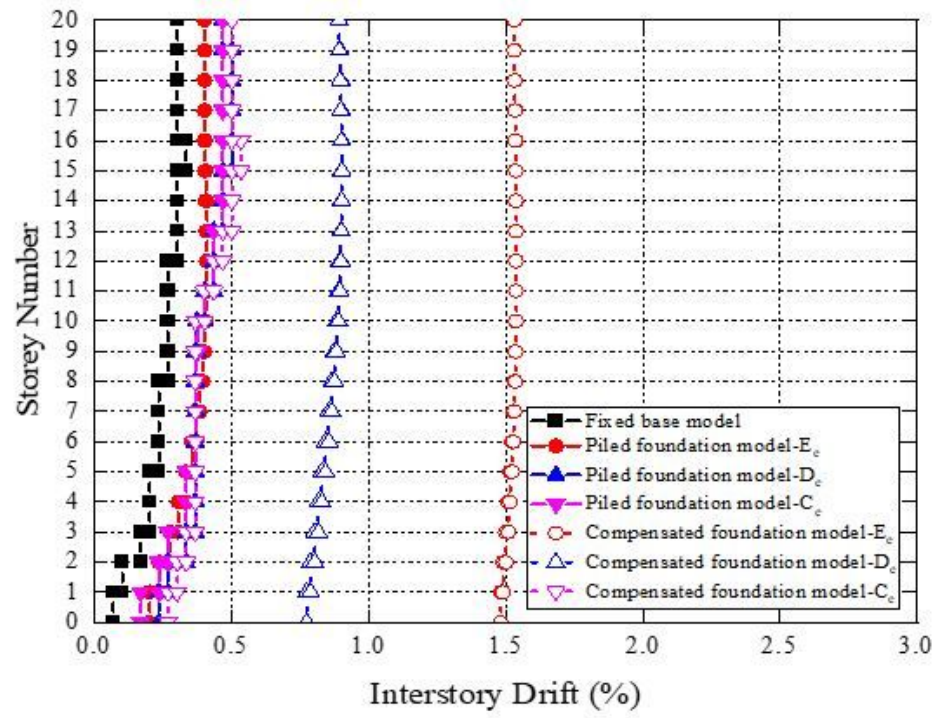

(b)

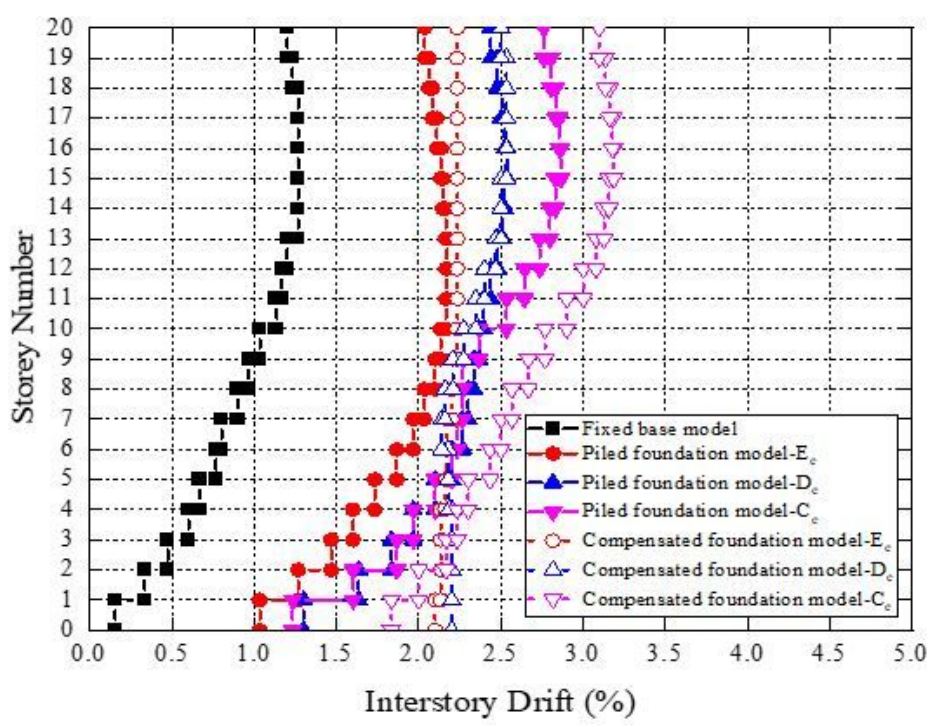

(d)

Figure 18

Inter-storey drifts of 20-storey structure (height-width ratio=6) with various foundation types and subsoil types under different seismic records: (a) El Centro earthquake (b) Hachinohe earthquake (c) Kobe earthquake (d) Northridge earthquake 


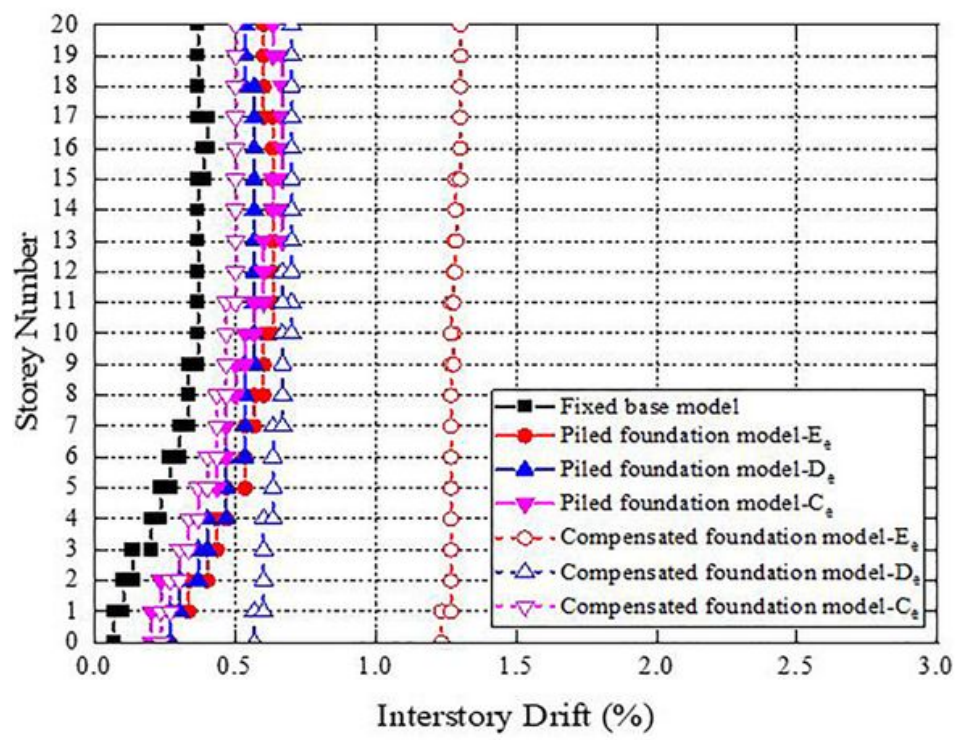

(a)

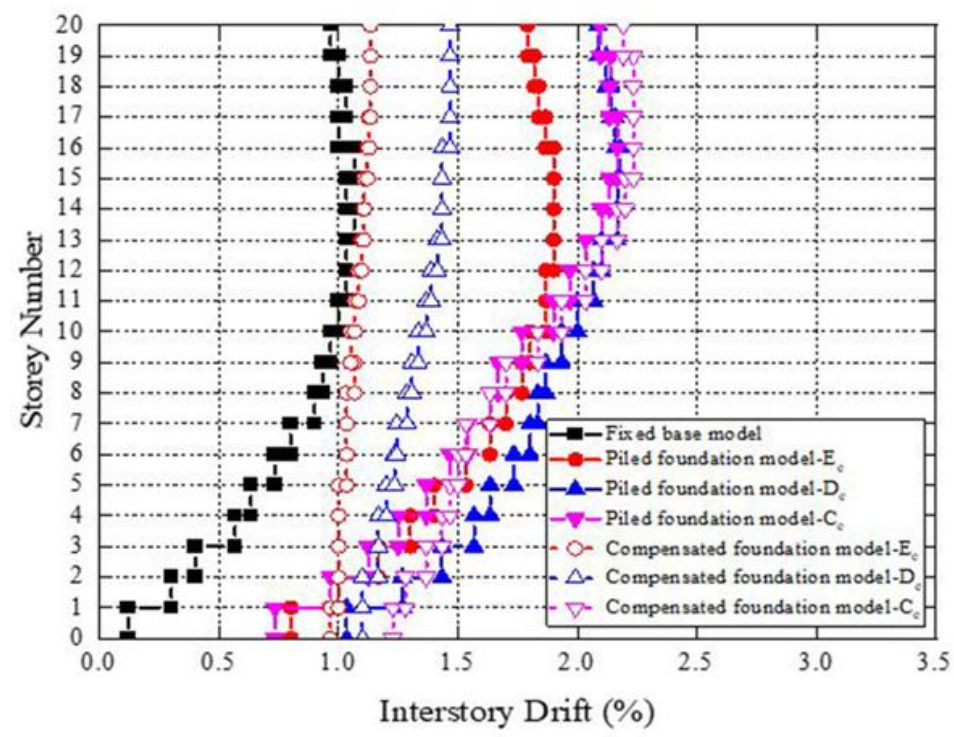

(c)

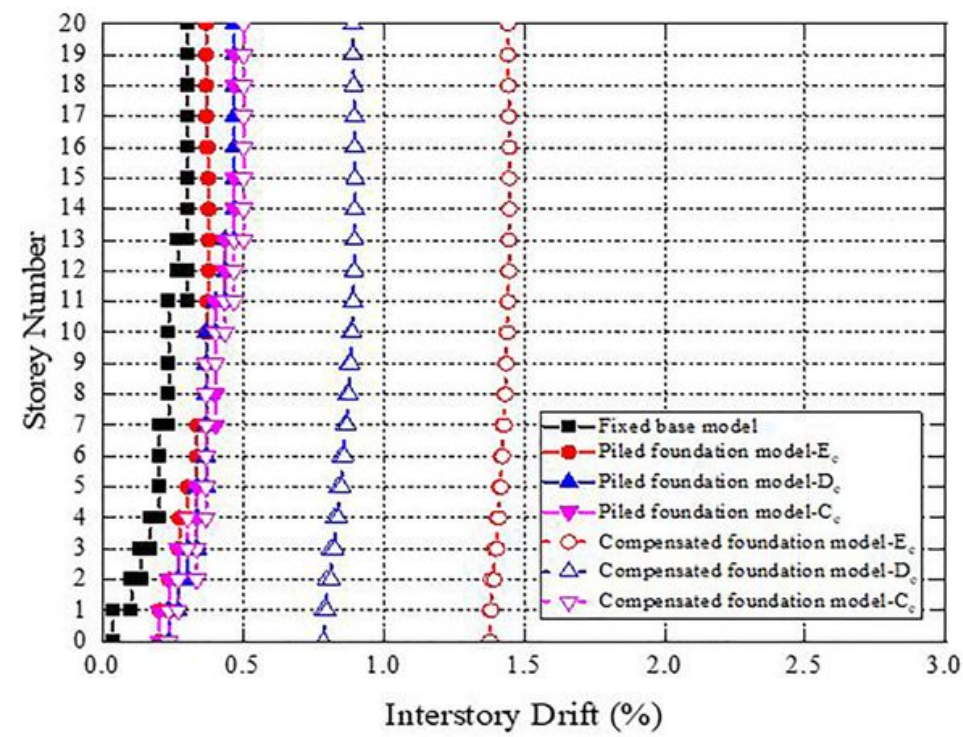

(b)

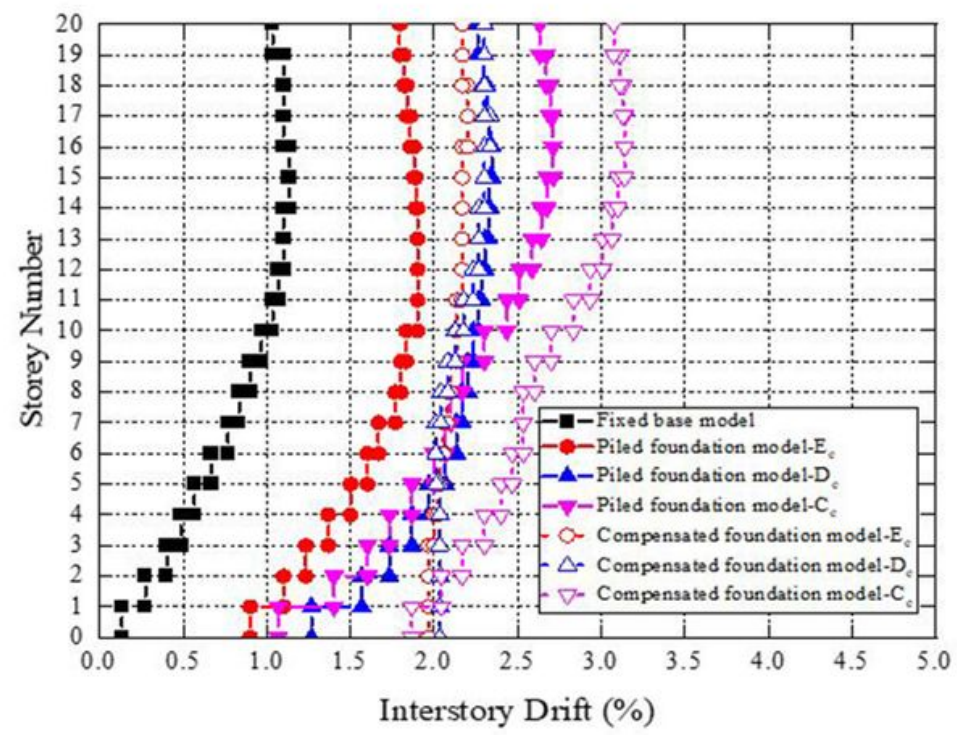

(d)

\section{Figure 19}

Inter-storey drifts of 20-storey structure (height-width ratio=5) with various foundation types and subsoil types under different seismic records: (a) El Centro earthquake (b) Hachinohe earthquake (c) Kobe earthquake (d) Northridge earthquake 


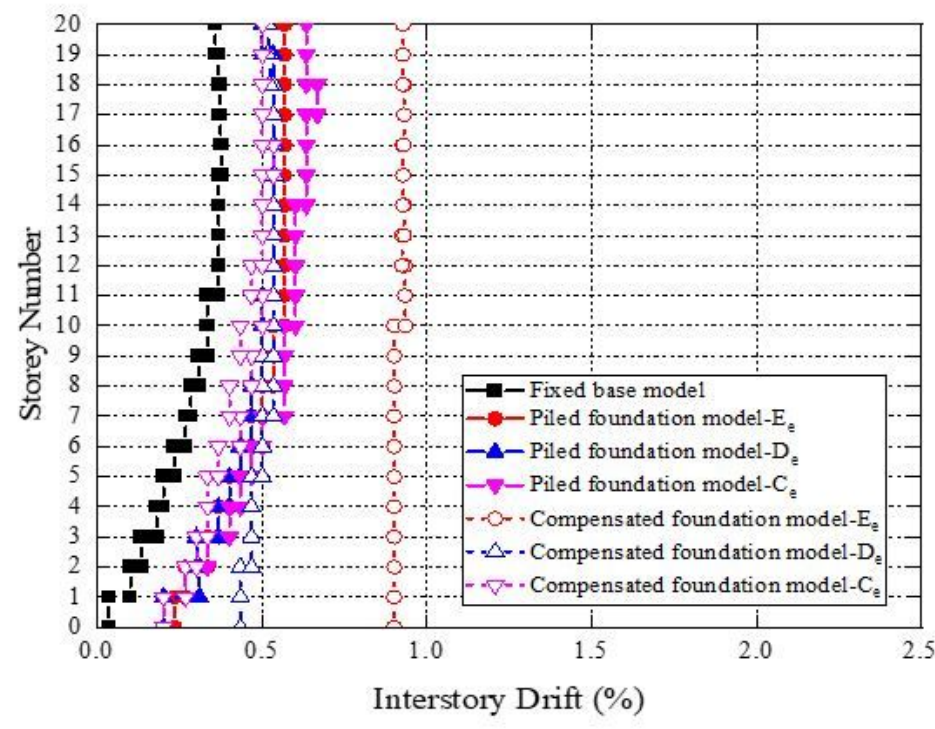

(a)

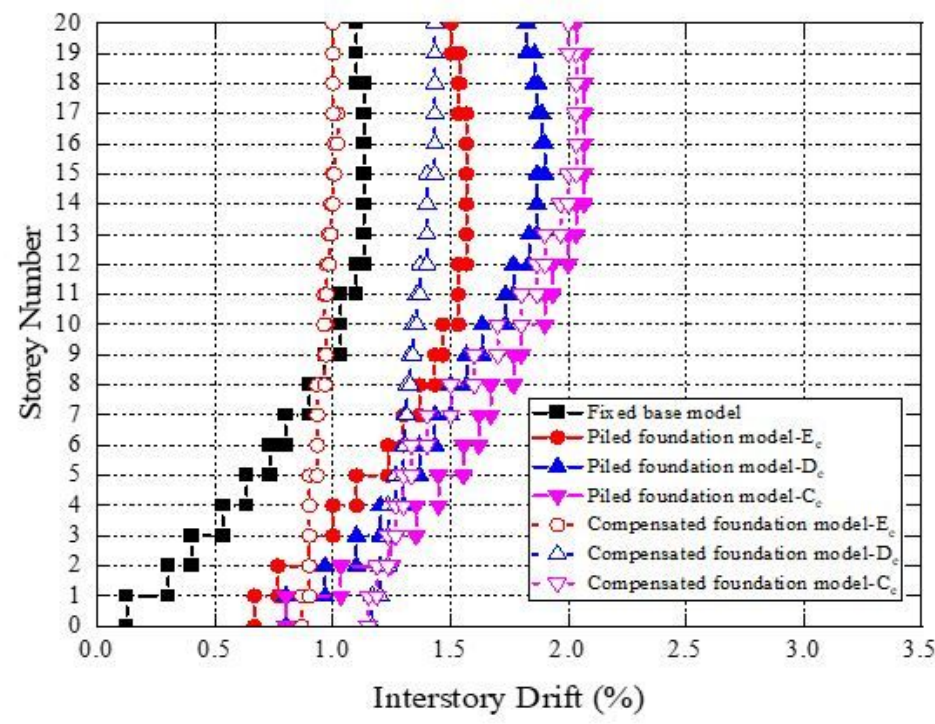

(c)

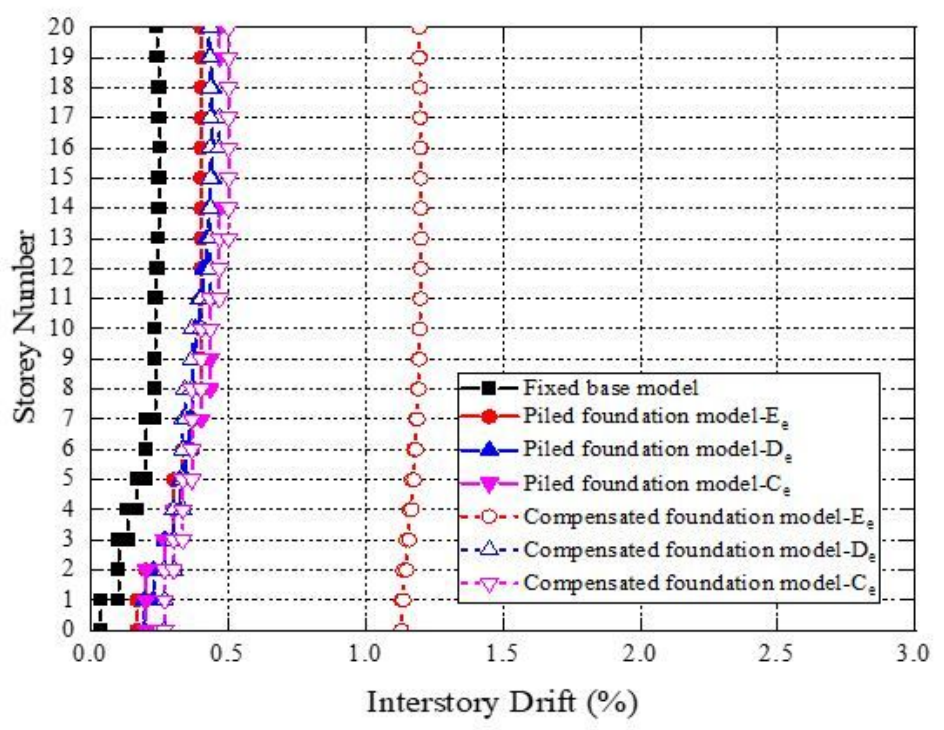

(b)

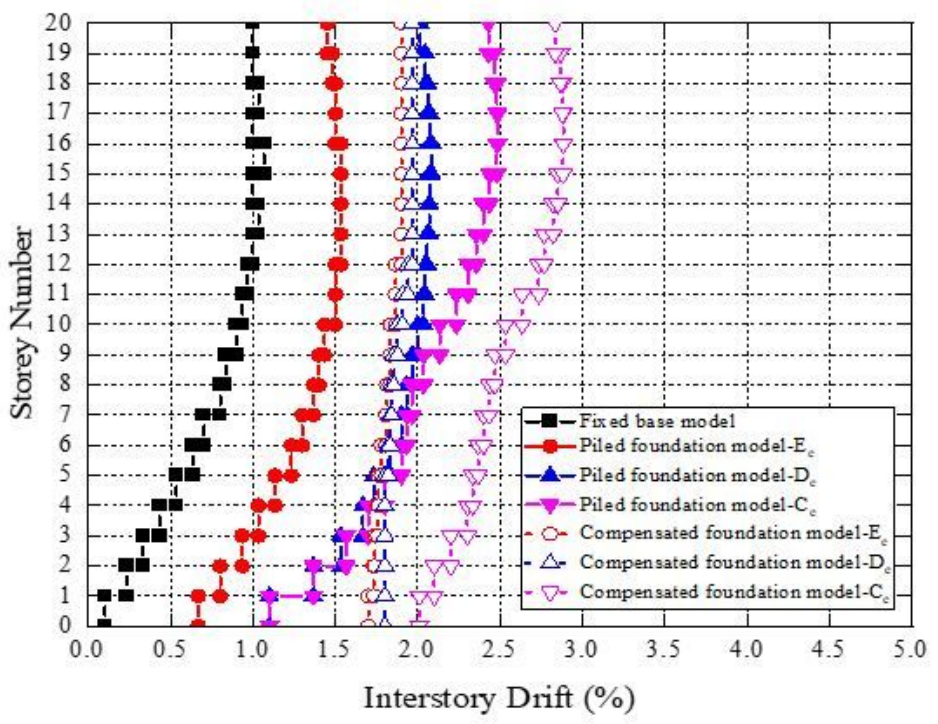

(d)

\section{Figure 20}

Inter-storey drifts of 20-storey structure (height-width ratio=4) with various foundation types and subsoil types under different seismic records: (a) El Centro earthquake (b) Hachinohe earthquake (c) Kobe earthquake (d) Northridge earthquake 


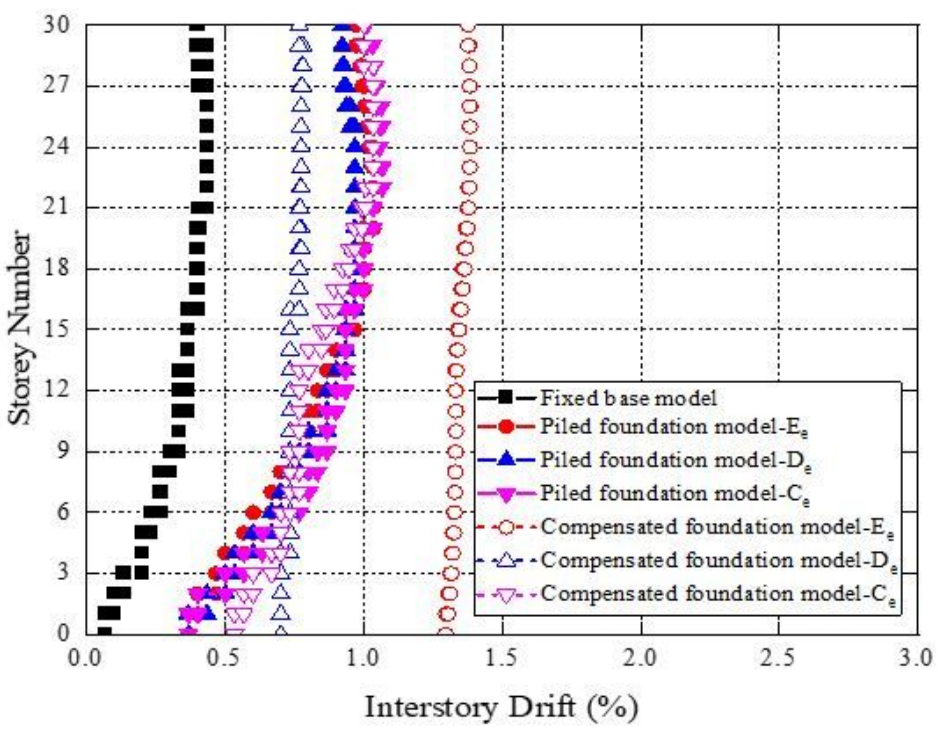

(a)

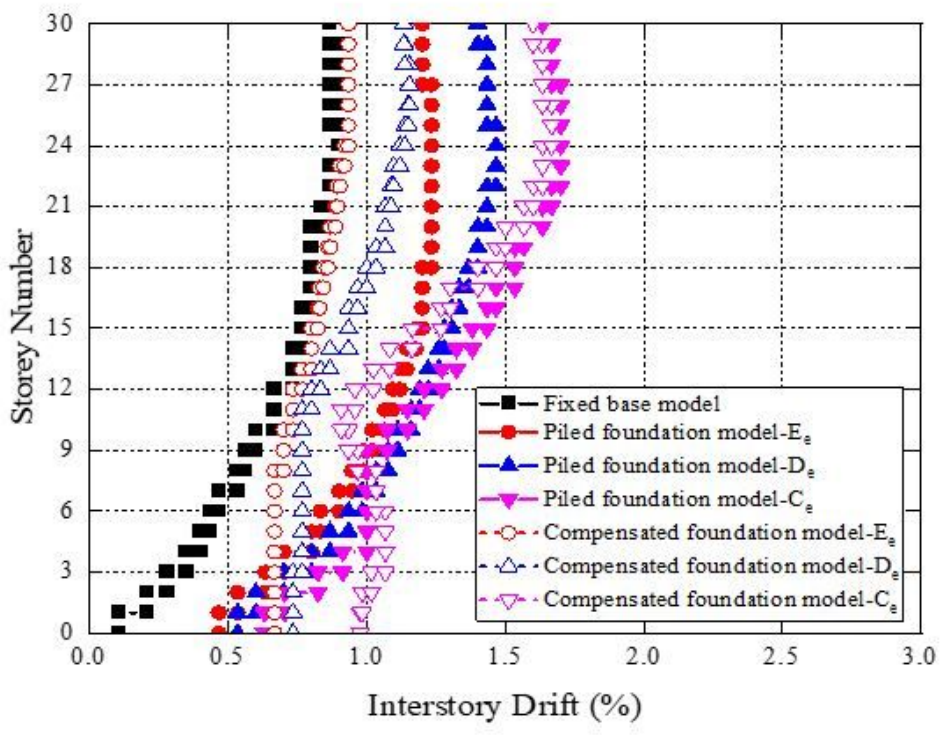

(c)

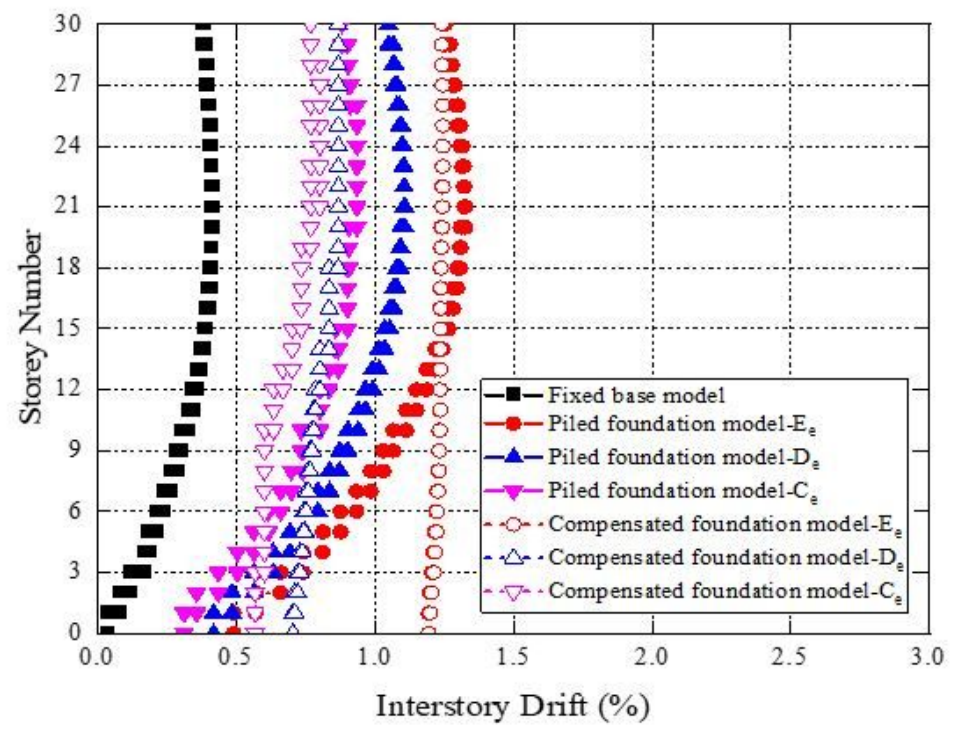

(b)

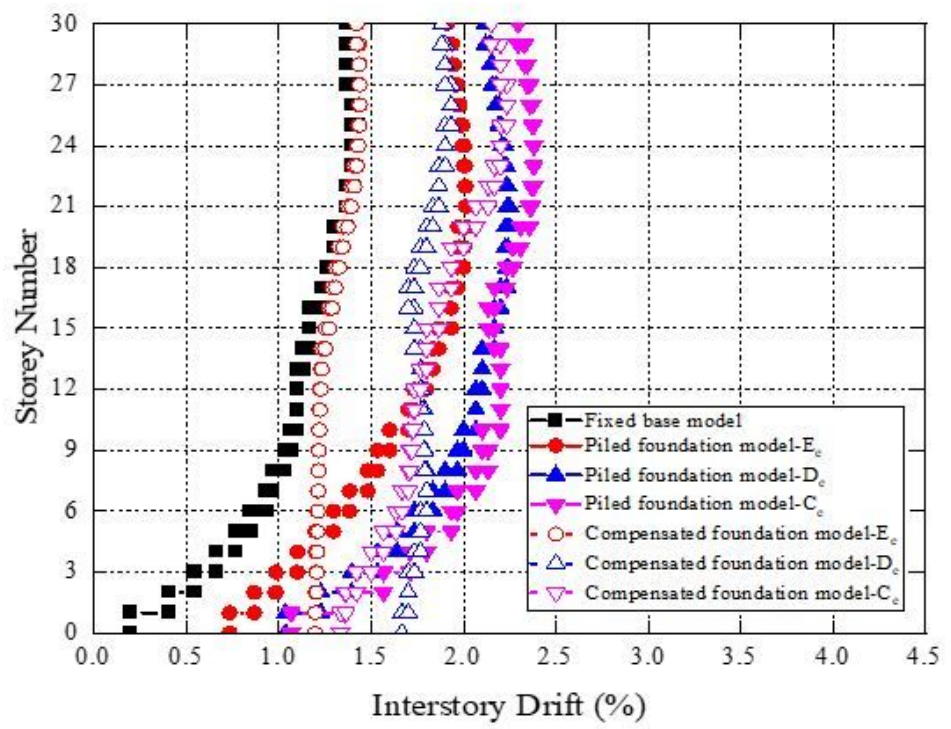

(d)

Figure 21

Inter-storey drifts of 30-storey structure (height-width ratio=6) with various foundation types and subsoil types under different seismic records: (a) El Centro earthquake (b) Hachinohe earthquake (c) Kobe earthquake (d) Northridge earthquake 


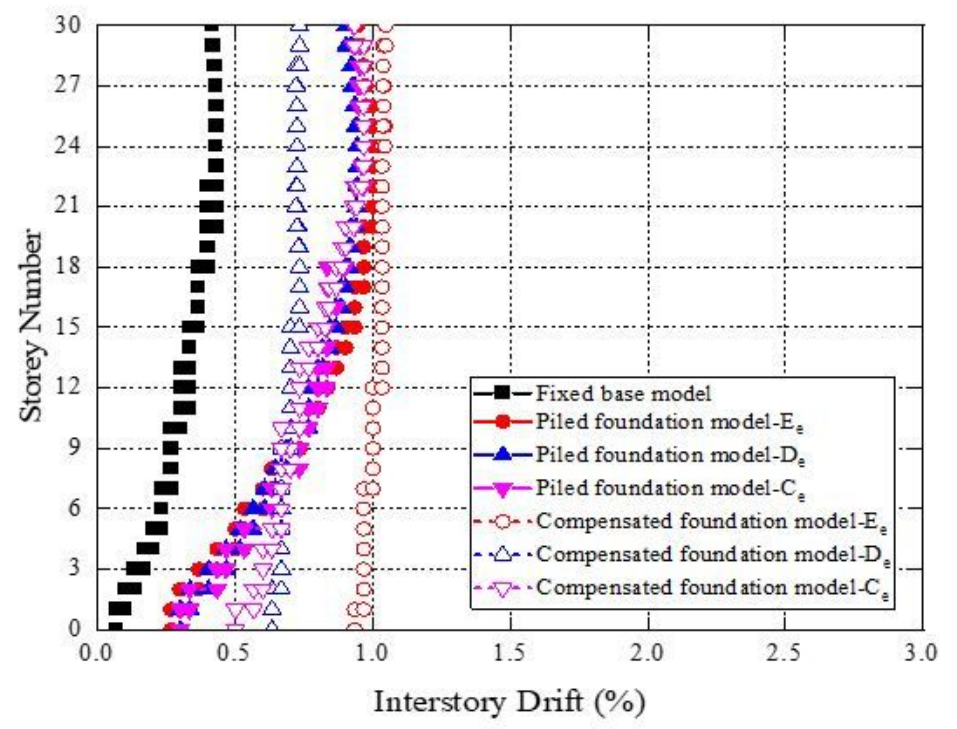

(a)

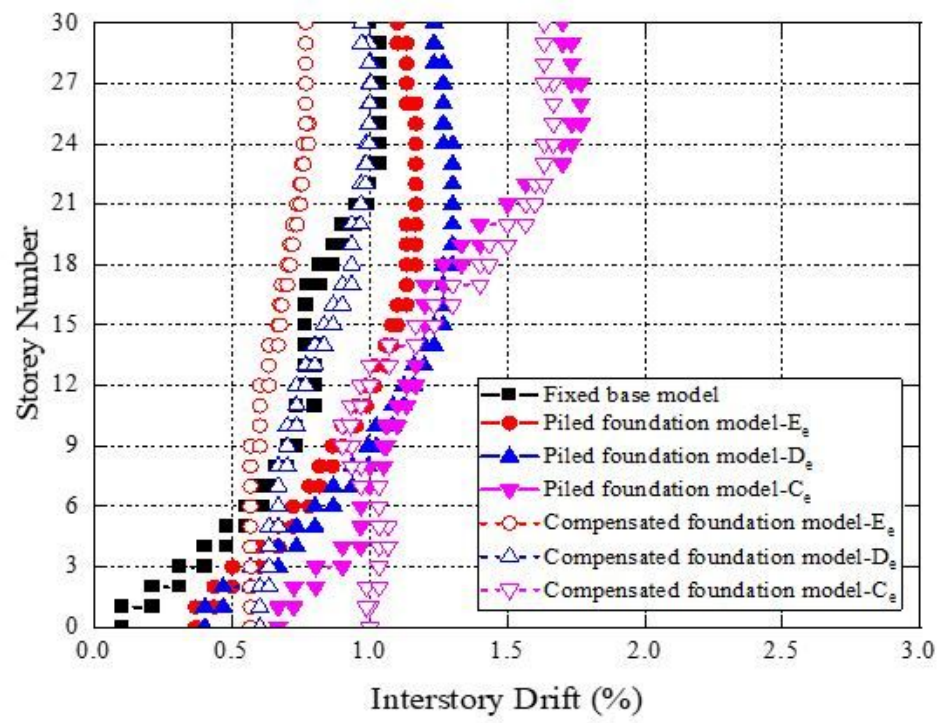

(c)

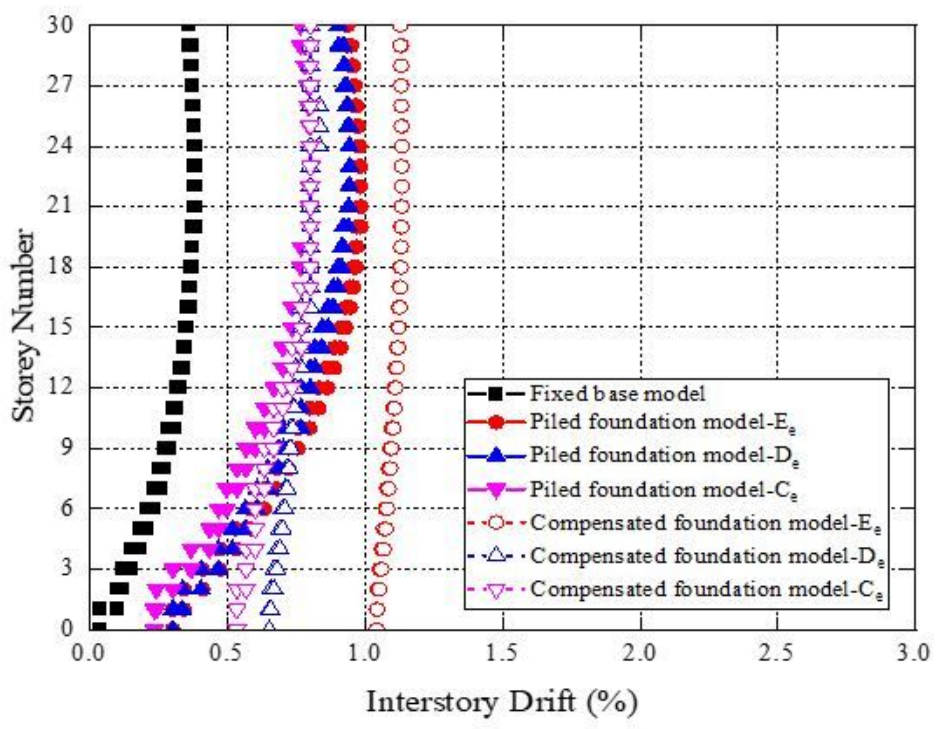

(b)

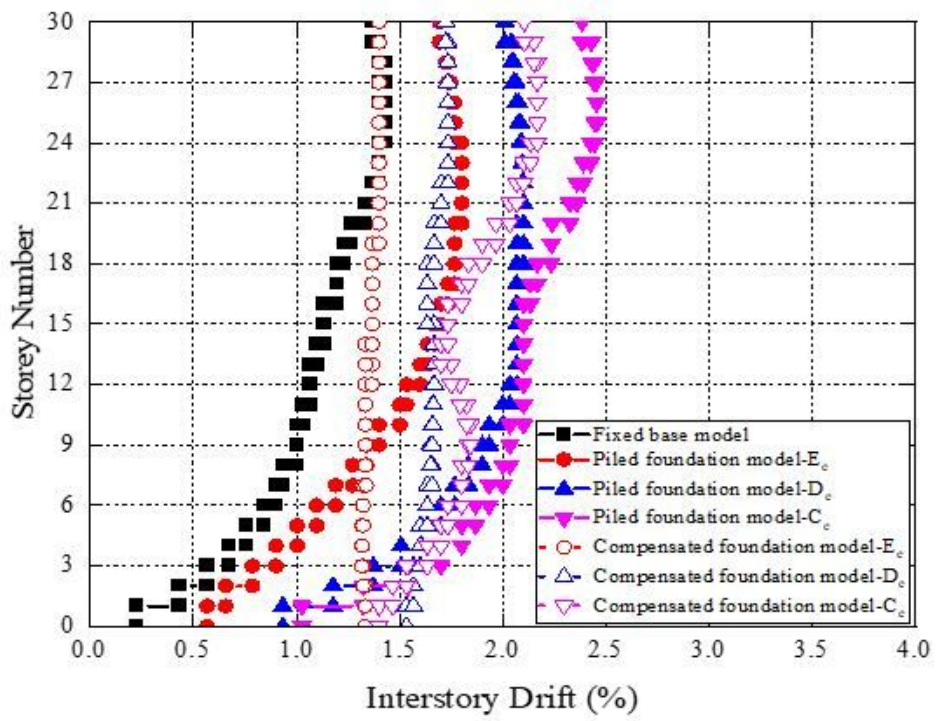

(d)

Figure 22

Inter-storey drifts of 30-storey structure (height-width ratio=5) with various foundation types and subsoil types under different seismic records: (a) El Centro earthquake (b) Hachinohe earthquake (c) Kobe earthquake (d) Northridge earthquake 


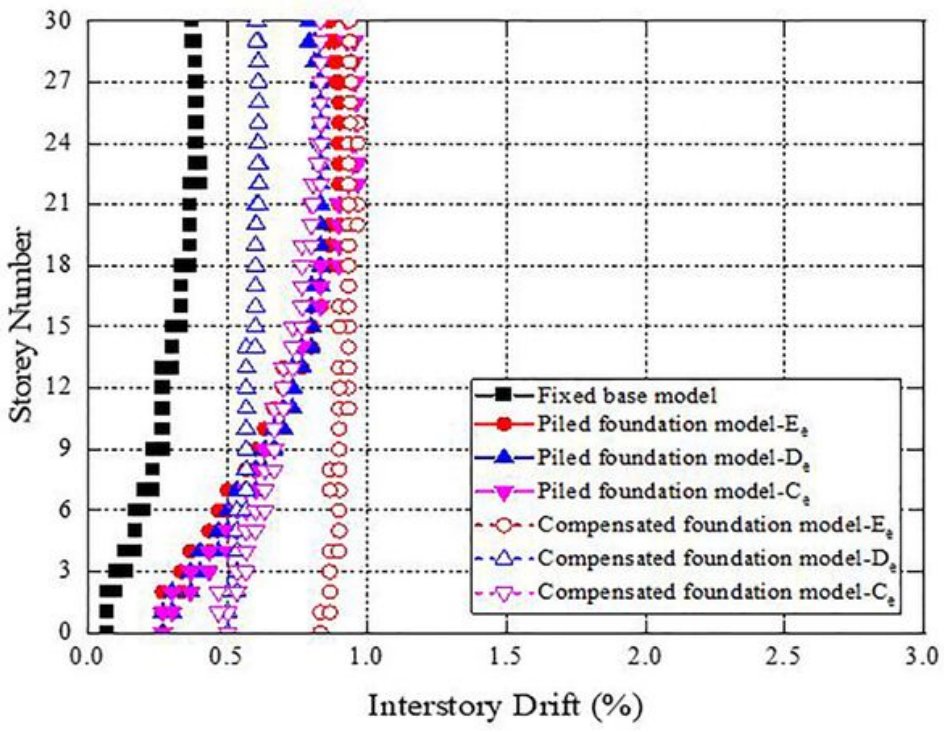

(a)

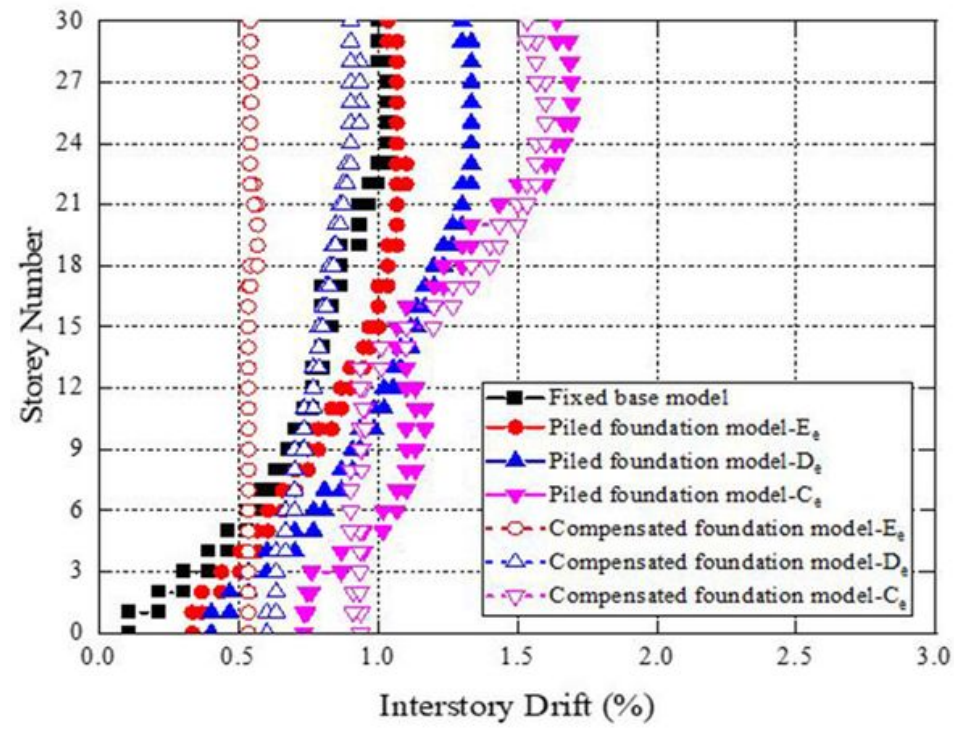

(c)

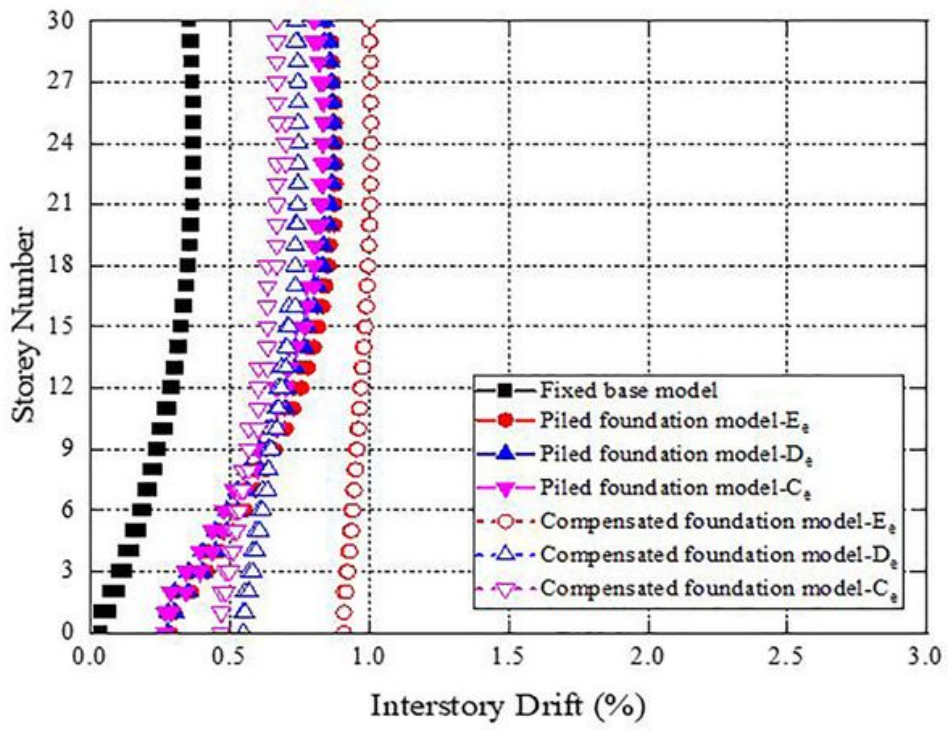

(b)

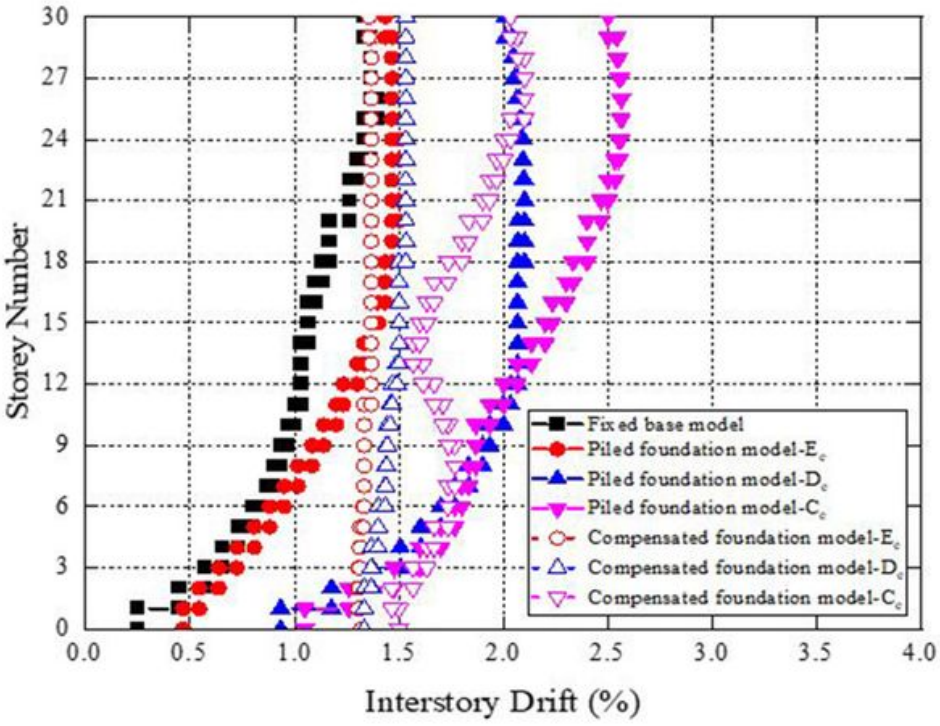

(d)

Figure 23

Inter-storey drifts of 30-storey structure (height-width ratio=4) with various foundation types and subsoil types under different seismic records: (a) El Centro earthquake (b) Hachinohe earthquake (c) Kobe earthquake (d) Northridge earthquake 


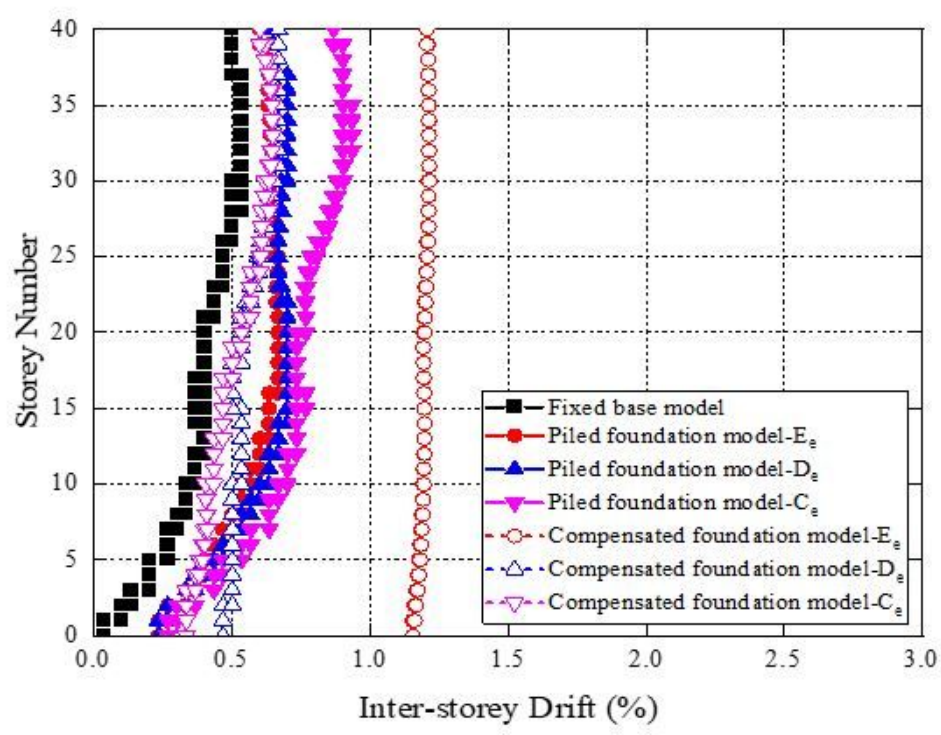

(a)

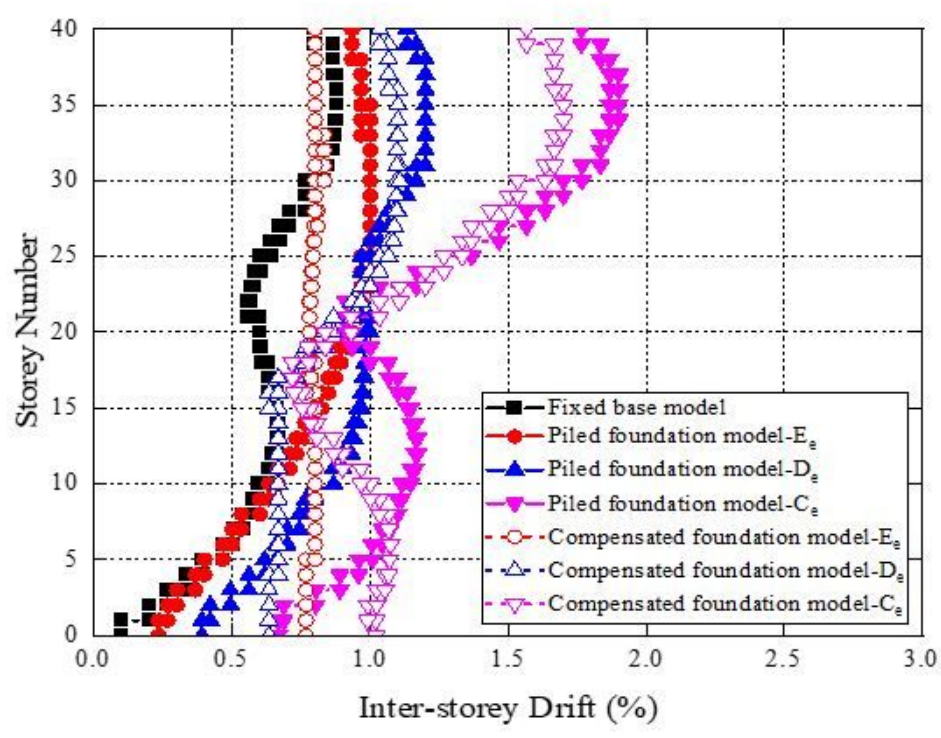

(c)

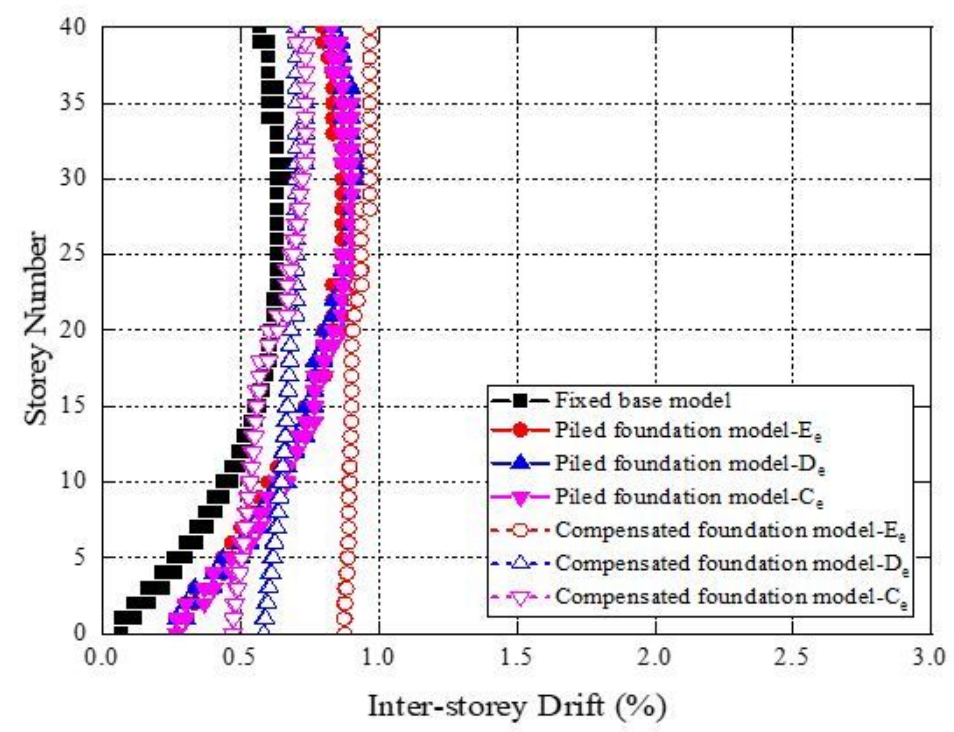

(b)

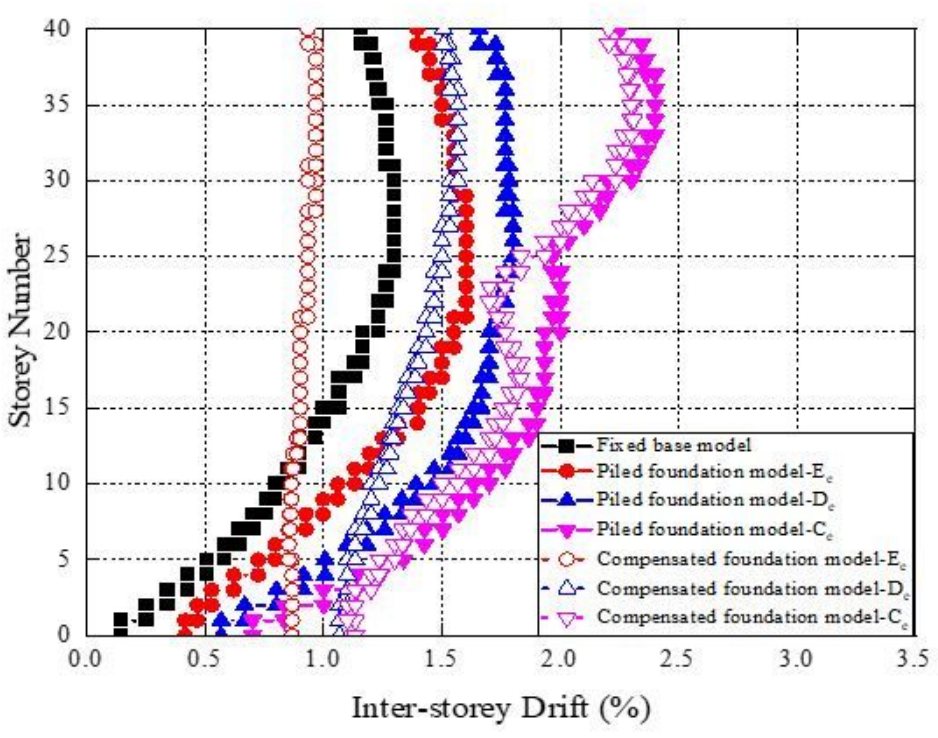

(d)

\section{Figure 24}

Inter-storey drifts of 40-storey structure (height-width ratio=6) with various foundation types and subsoil types under different seismic records: (a) El Centro earthquake (b) Hachinohe earthquake (c) Kobe earthquake (d) Northridge earthquake 


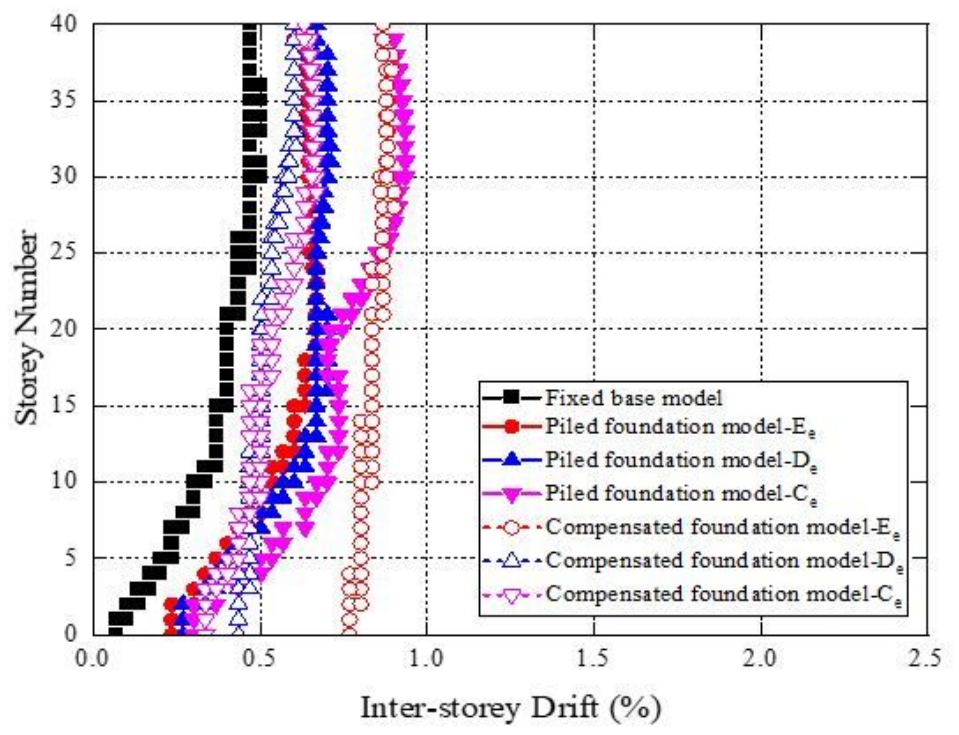

(a)

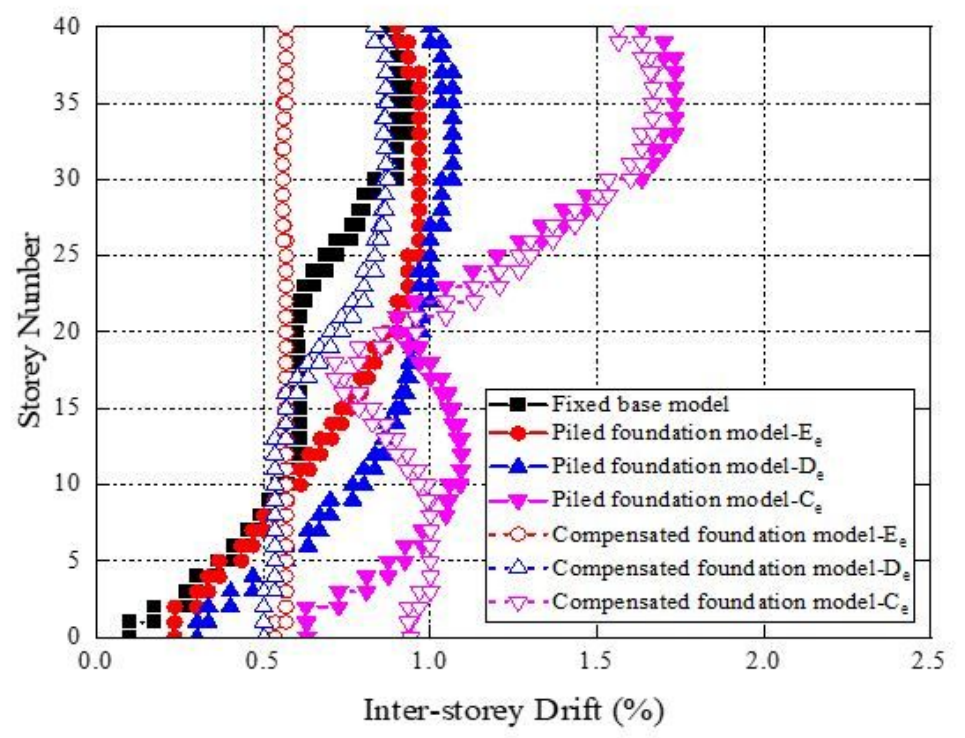

(c)

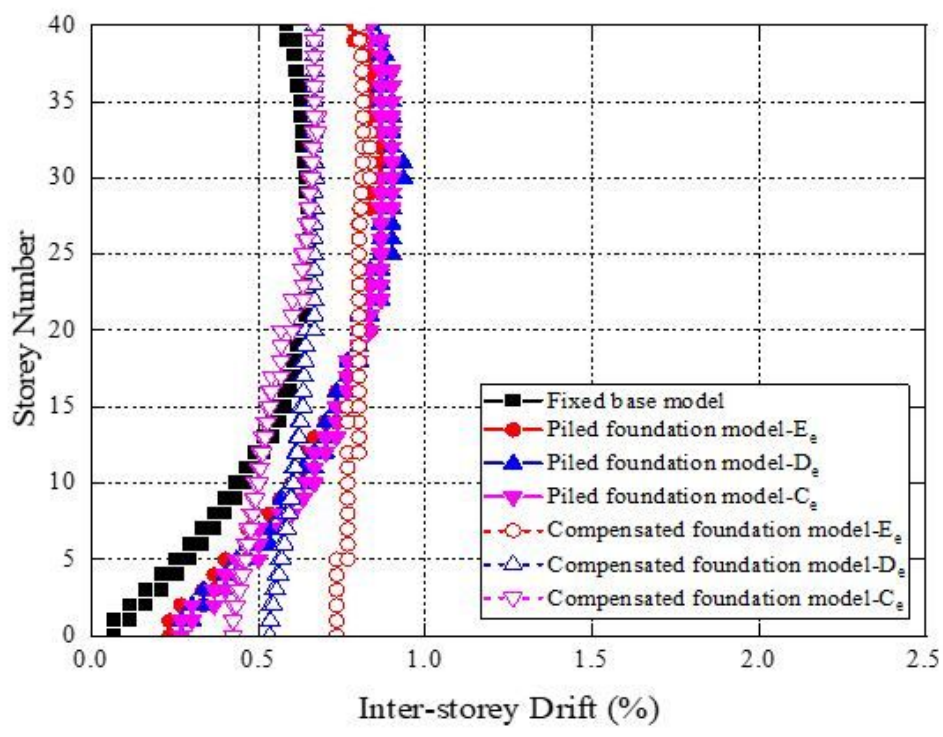

(b)

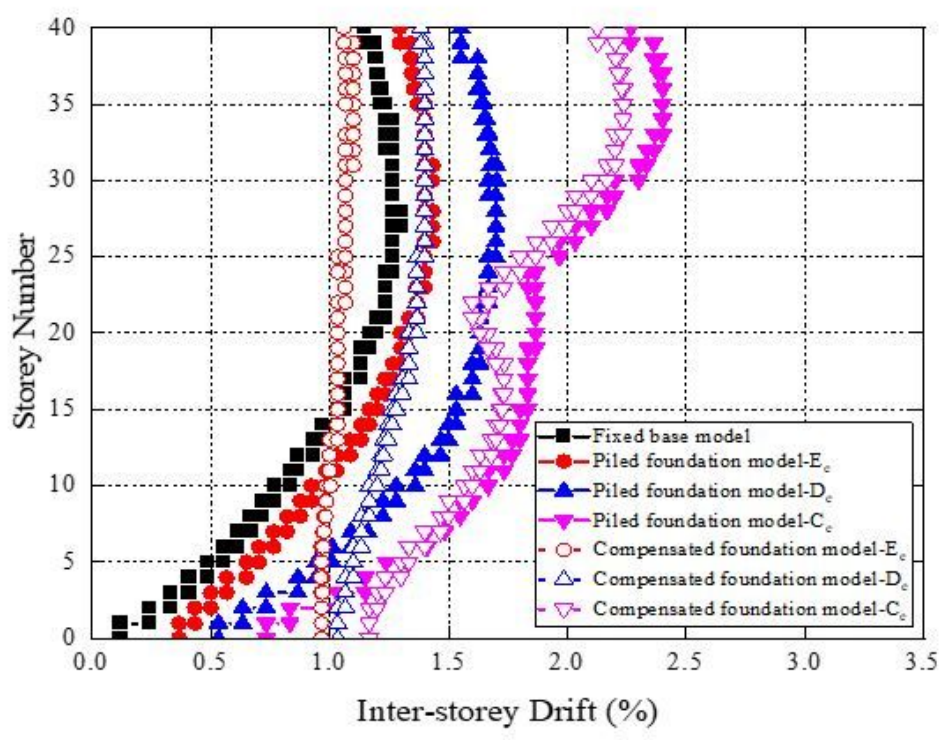

(d)

\section{Figure 25}

Inter-storey drifts of 40-storey structure (height-width ratio=5) with various foundation types and subsoil types under different seismic records: (a) El Centro earthquake (b) Hachinohe earthquake (c) Kobe earthquake (d) Northridge earthquake 


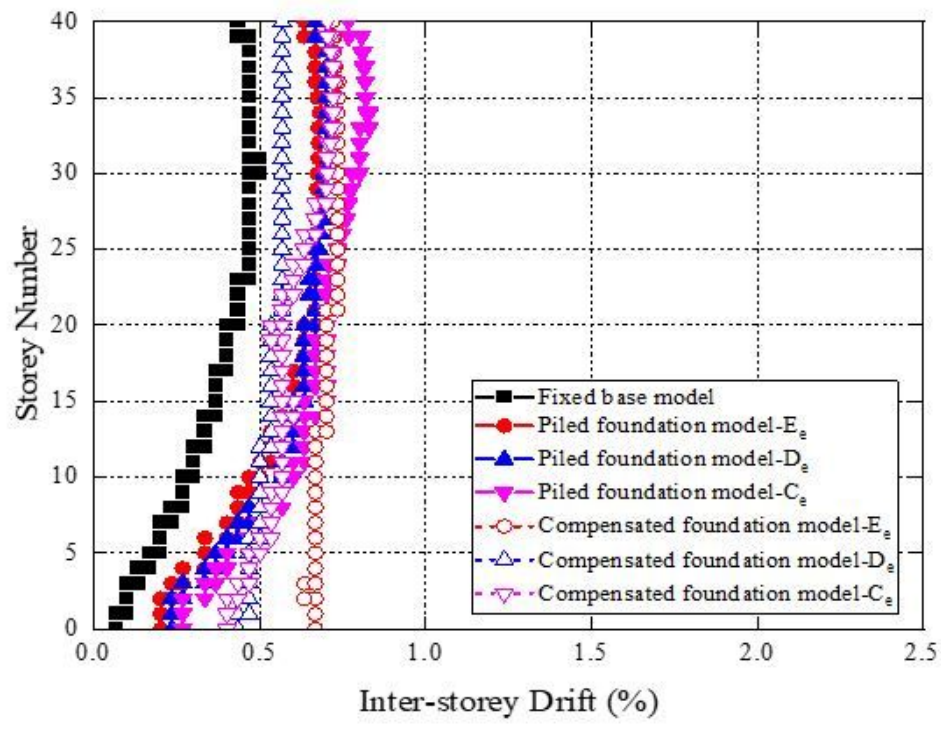

(a)

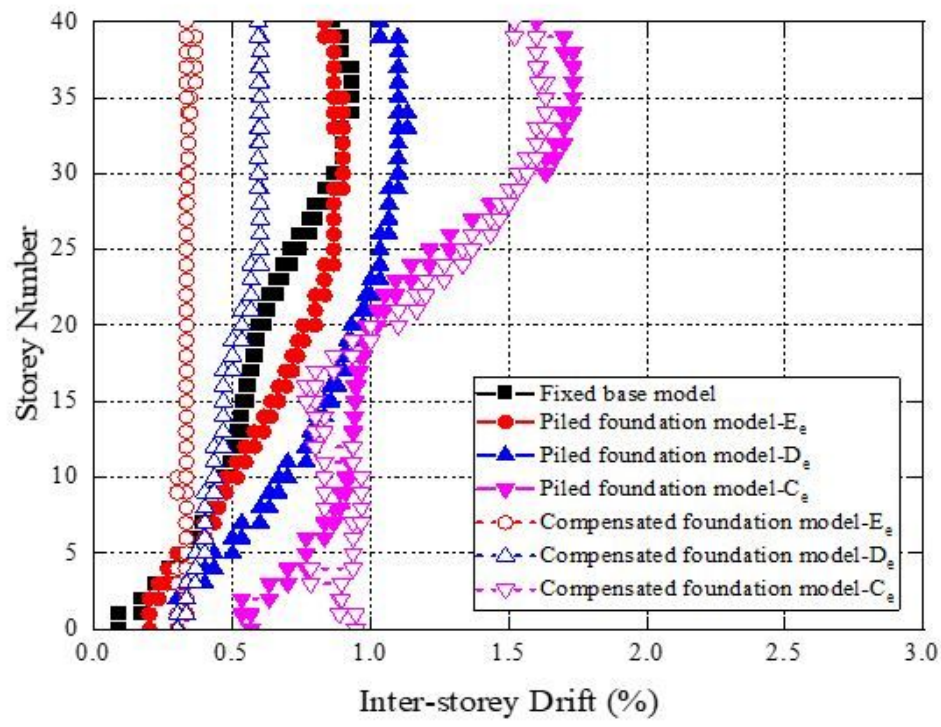

(c)

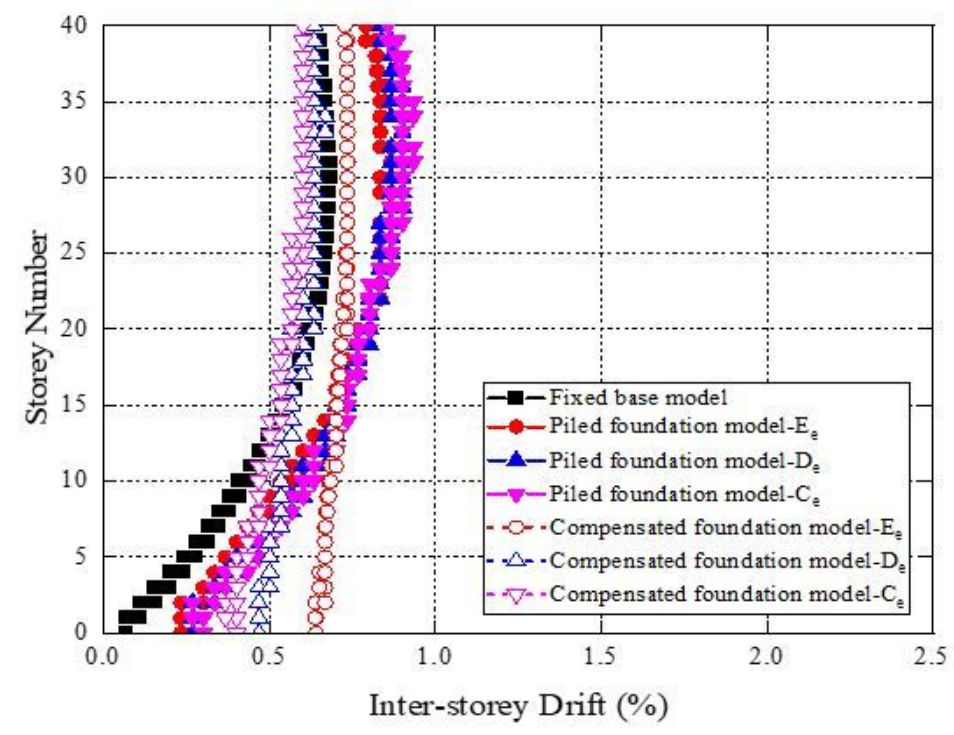

(b)

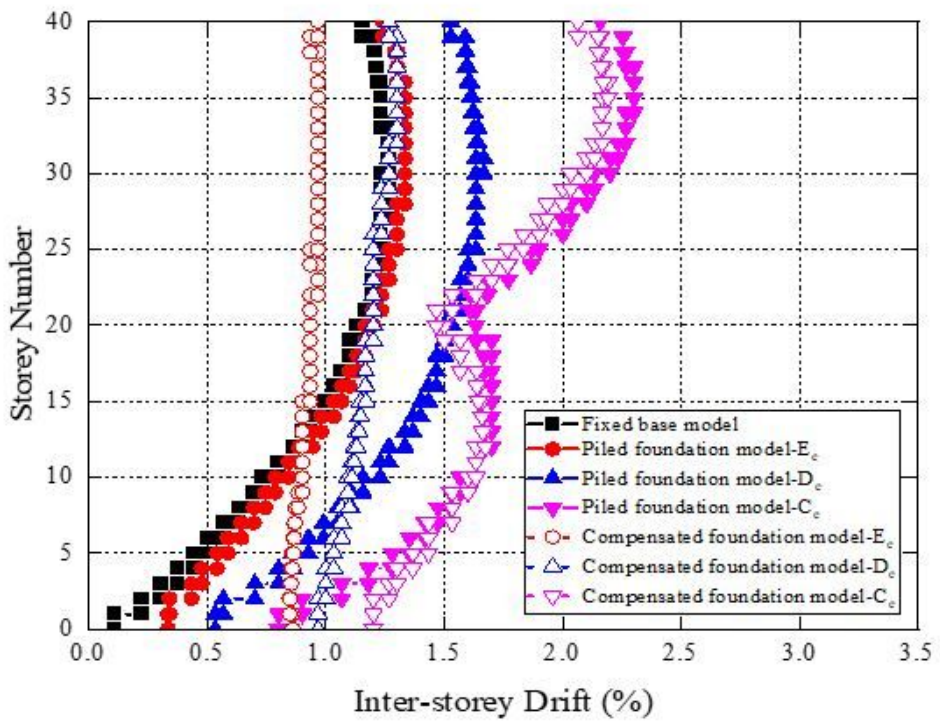

(d)

\section{Figure 26}

Inter-storey drifts of 40-storey structure (height-width ratio=4) with various foundation types and subsoil types under different seismic records: (a) El Centro earthquake (b) Hachinohe earthquake (c) Kobe earthquake (d) Northridge earthquake 